\title{
Polycrystalline Thin Film Materials and Devices
}

\section{Annual Subcontract Report 16 January 1991 - 15 January 1992}

B. N. Baron, R. W. Birkmire, J. E. Phillips, W. N. Shafarman, S. S. Hegedus, B. E. McCandless Institute of Energy Conversion Newark, Delaware

NREL technical monitor: B. von Roedern

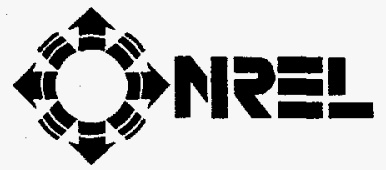

National Renewable Energy Laboratory 1617 Cole Boulevard Golden, Colorado 80401-3393

A Division of Midwest Research Institute Operated for the U.S. Department of Energy under Contract No. DE-AC02-83CH10093

Prepared under Subcontract No. XN-0-10023-1

October 1992 
On September 16, 1991 the Solar Energy Institute was designated a national laboratory, and its name was changed to the National Renewable Energy Laboratory.

\title{
NOTICE
}

This report was prepared as an account of work sponsored by an agency of the United States government. Neither the United States government nor any agency thereof, nor any of their employees, makes any warranty, express or implied, or assumes any legal liability or responsibility for the accuracy, completeness, or usefulness of any information, apparatus, product, or process disclosed, or represents that its use would not infringe privately owned rights. Reference herein to any specific commercial product, process, or service by trade name, trademark, manufacturer, or otherwise does not necessarily constitute or imply its endorsement, recommendation, or favoring by the United States government or any agency thereof. The views and opinions of authors expressed herein do not necessarily state or reflect those of the United States government or any agency thereof.

\author{
Printed in the United States of America \\ Available from: \\ National Technical Information Service \\ U.S. Department of Commerce \\ 5285 Port Royal Road \\ Springfield, VA 22161
}

Price: Microfiche A01

Printed Copy AOS

Codes are used for pricing all publications. The code is determined by the number of pages in the publication. Information pertaining to the pricing codes can be found in the current issue of the following publications which are generally available in most libraries: Energy Research Abstracts (ERA); Government Reports Announcements and Index (GRA and I); Scientific and Technical Abstract Reports (STAR); and publication NTIS-PR-360 available from NTIS at the above address. 


\section{DISCLAIMER}

Portions of this document may be illegible electronic image products. Images are produced from the best available original document. 
Results and conclusions of Phase II of a multi-year research program on polycrystalline thin film heterojunction solar cells are presented. The research consisted of the investigation of the relationships between processing, materials properties and device performance. This relationship was quantified by device modeling and analysis. The analysis of thin film polycrystalline heterojunction solar cells explains how minority carrier recombination at the metallurgical interface and at grain boundaries can be greatly reduced by the proper doping of the window and absorber layers. Additional analysis and measurements show that the present solar cells are limited by the magnitude of the diode current which appears to be caused by recombination in the space charge region.

Developing an efficient commercial scale process for fabricating large area polycrystalline thin film solar cells from a research process requires detailed understanding of the individual steps in making the solar cell and their relationship to device performance and reliability. The complexities involved in characterizing a process are demonstrated with results from our research program on CuInSe $_{2}$ and CdTe processes. 


\section{SUTMMARY}

\section{objectives}

The objectives of this research are to obtain the understanding of the materials processing, properties and performance of polycrystalline thin-film CuInse, and CdTe solar cells that are needed to achieve the goals for efficiency, reliability and cost for flat plate thin-film photovoltaic systems set by DOE for the National Photovoltaics Program. A further objective of this program is to support the development of a competitive U.S. photovoltaic industry through collaboration with engineers and scientists at other laboratories.

\section{Discussion}

This is a report on Phase II of a three year phased research program of integrated investigations of processing, properties, and performance of polycrystalline thin film CuInse ch $_{2}$ and based heterojunction solar cells.

Research on the mode(s) of operation of these devices has given the following indications.

The effect of interface recombination on the light generated current in a thin film heterojunction solar cell can be reduced by making sure that most of the junction built-in voltage (or diffusion voltage) is across the absorber layer at the interface.

The loss of minority carriers to grain boundary recombination in the polycrystalline absorber can be reduced if the grain boundary edges are more heavily doped than the bulk.

Because of the two dimensional problem created by the grain boundaries, simple one dimensional modeling will only give "averaged" values for the electronic properties of the absorber.

From current-voltage measurements, it appears that recombination in the space charge region of the absorber controls the diode current during solar cell operation.

Analysis of the J-V characteristics as a function of temperature has shown that the CuInSe, cells are controlled by a single current mechanism, SRH recombination. There is no evidence of a transition to a lower A factor at forward bias as had been predicted by a standard interface recombination model. And the diode behavior at a given intensity is described by the standard temperature dependence with no evidence of tunnelling or other mechanisms with different temperature dependence.

The light intensity dependence of $A, G$, and $J$ o indicates further

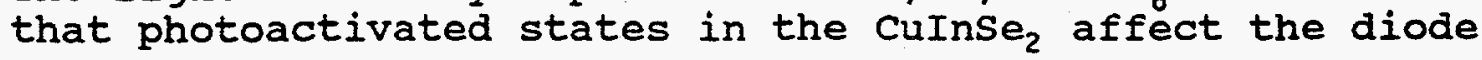


current. In the case of CdTe; if the voltage dependent current collection $\left(J_{L}(V)\right.$ ) as shown by spectral response measurements is included in the diode analysis of current-voltage measurements made under illumination, then both the dark and light analysis give a barrier height $(\phi)$ near $1.3 \mathrm{eV}$ with a diode quality factor (A) of about 1.8. These are indications that the CaTe/Cas solar cell operates as a $p-n$ heterojunction and has a current transport mechanism dominated by Shockley-Read-Hall recombination in the space charge region of the cate.

Analysis of the process used for fabricating research solar cells and its relationship to material properties and device performance will become increasingly important as thin film polycrystalline solar cells are commercialized. In order to effectively characterize a process, an integrated research approach is required so that material properties and device performance can be coupled with the process analysis. In the case of CdTe solar cells, we have used evaporated CdTe solar cells as a model system and developed a self consistent picture, based on materials and devices measurements, of the effects of processing on the evolution of a CaTe cell which can be applied to other processing methods. For cuInse formation by selenization, a clear understanding of the process is only beginning to emerge.

The reaction pathways to CuInse ${ }_{2}$ formation using either $\mathrm{H}_{2} \mathrm{Se}$ or Se proceed through the formation of the $\mathrm{Cu}_{11} I_{n_{9}}$ phase and the indium selenide phases ( In $_{2} \mathrm{Se}$ and InSe). The only different precursor in the two schemes is the copper selenide phase observed in the selenization in Se vapor. The reaction with se also proceeds faster than the reaction with $\mathrm{H}_{2} \mathrm{Se}$. Below $400^{\circ} \mathrm{C}$ the phases observed in the reaction with $\mathrm{H}_{2} \mathrm{Se}$ at a temperature $\mathrm{T}$ are observed in the reaction with $\mathrm{Se}$ at a temperature $\mathrm{T}-50^{\circ} \mathrm{C}$.

It appears, on a preliminary examination, that the binary

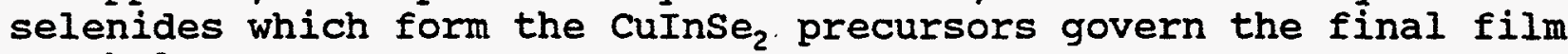
morphology.

Analysis of cdTe/Cds devices fabricated by vacuum evaporation has led to a consistent picture of the effects of processing on the evolution of the cells which is extendable to devices fabricated by other methods. High temperature processing or post deposition annealing in the presence of $\mathrm{CaCl}_{2}$ results in both CaTe grain growth and interdiffusion of the cds and cdTe films. The amount of the diffusion of $T e$ into the cas depends on the cas thickness and structure. The device structure is most likely $\mathrm{CdS}_{1-y} \mathrm{Te}_{y} / \mathrm{CdTe}_{1-x} \mathrm{~S}_{x}$ with the $\mathrm{CdS}_{1-y} \mathrm{Te}_{y}$ reducing the short wavelength spectral response and the $\operatorname{cdTe}_{1-x} S_{x}$ enhancing the long wavelength spectral response. $C u$ or other acceptor dopants used in most fabricating processes convert the cdTe from intrinsic or n-type to p-type. A quantitative analysis of the relation between deposition and post-deposition processing to 
optimized device performance will be required to develop an efficient commercial process.

CaTe solar cells that have been tested over periods ranging in time from three months to nearly three years have been found to change in efficiency (both up and down). This change is associated with a change in the effective series resistance. We would expect this type of change to be associated with the contacting. However, the changes do not necessarily correlate with cells on the same sample which should have had the same processing. It is suspected that the preparation or treatment of the CdTe surface prior to contacting is involved in these changes. Further work along these lines is continuing. 


\section{List of Contributors}

Bill N. Baron

Robert W. Birkmire

James E. Phillips

William N. Shafarman

Steven $\mathbf{S}$. Hegedus

Brian E. Mccandless

Takashi Yoshida (Fuji)

Satoshi Yamanaka

Anup Mondal

Sandeep Verma

Robert D. Varrin, Jr.

Wayne A. Buchanan

Herbert 0 . Wardell

Sarah K. Buchanan

Sally I. Gordon

Ronald Dozier

David A. Fardig

Iaurie Adkins

Elaine A. Koronik
Project Director

Principal Investigator

Principal Investigator

Principal Researcher

Principal Researcher

Principal Researcher

Visiting scientist

Post Doctoral Fellow

Post Doctoral Fellow

Graduate student

Graduate Student

Technical support

Technical support

Technical support

Technical support

Technical Support

cdTe Research

student

Document Preparation

David Albin (NREI)

Scot Albright (Photon Energy Inc.)

Rajeewa Arya (Solarex Corp.)

Anthony Catalano (Solarex Corp.)

Ting chu (Univ. of South Florida)

Chris Eberspacher (Siemens Solar Industries)

Kim Mitchell (Siemens Solar Industries)

Keith Emery (NREL)

Fouad Abou-Elfotouh (NREL)

Zolton Kiss (EPV)

Peter Meyers (Solar Cells Inc.)

Alvin Compaan (Univ. of Toledo)

Terry Peterson (EPRI)

Angus Rockett (Univ. of Illinois)

Ajeet Rohatgi (Georgia Tech)

Axel Schonecker (Fraunhofer Institute, Germany)

James Sites (Colorado State Univ.)

Jarmo Skarp (Microchemistry, Finland) 


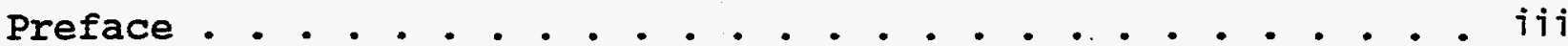

Summary .. . . . . . . . . . . . . . . . . . . . . iv

List of Contributors . . . . . . . . . . . . . . . . . vii

List of Figures . . . . . . . . . . . . . . . . . . . . ix

List of Tables . . . . . . . . . . . . . . . . . . xij

SECTION 1.0 Introduction . . . . . . . . . . . . . . . . . . . 1

1.1 Background . . . . . . . . . . . . . . . . . . . 1

1.2 Technical Approach . . . . . . . . . . . . . . . 2

1.3 Outline of Report . . . . . . . . . . . . . . . 3

SECTION 2.0 Device Modeling, Characterization and Analysis . . 4

2.1 Requirements of a Polycrystalline Heterojunction . . 4

2.2 Modes of operation and Limitations . . . . . . . . . 11

$2.3 \mathrm{CuInSe}_{2} /(\mathrm{Cdzn}) \mathrm{S}$ Device Operation . . . . . . . . . . 14

2.4 CdTe Device Operation . . . . . . . . . . . . 30

SECTION 3.0 Materials and Device Fabrication . . . . . . . . 46

3.1 CuInSe $_{2}$ Films . . . . . . . . . . . . . . . . . . . 46

3.2 Processing of CaTe Devices . . . . . . . . . . 60

SECTION 4.0 References . . . . . . . . . . . . . . . . . 81

SECTION 5.0 Abstract . . . . . . . . . . . . . . . 83

Appendix A . . . . . . . . . . . . . . . . . . . . 85

Appendix B . . . . . . . . . . . . . . . . . . . . 86 
Figure 1 Energy band diagram of an AlGaAs/GaAs heteroface

cell.

Figure 2 Energy band diagram of an AlGaAs/GaAs

heterojunction cell. . . . . . . . . . . . 7

Figure 3 Energy band diagram of an n-p heterojunction cell . 8

Figure 4 Cross section of a polycrystalline cell . . . . . 9

Figure 5 Energy band diagrams of polycrystalline grain

boundaries .. . . . . . . . . . . . . 10

Figure 6 Energy band schematic of the diode current in a

heterojunction cell. . . . . . . . . . . . 12

Figure 7 Model of currents controlled by SRH $(A=1.7)$ and

interface $(A=1)$ recombination and their sum. . . . 16

Figure 8 Fill factor calculated from standard diode equation

3 with no resistance or shunt losses at $\mathrm{T}=25^{\circ} \mathrm{C}$. . . 17

Figure $9 \mathrm{~J}-\mathrm{V}$ curves of cell 2 at four temperatures. A back diode is seen at forward bias for $\mathrm{T}<25^{\circ} \mathrm{C}$. . . . . 20

Figure $10 \ln (\mathrm{J})-\mathrm{V}$ of $\operatorname{cell} 2$ at $\mathrm{T}=55^{\circ} \mathrm{C}$ and four intensities. . 21

Figure 11 Determination of $G$ at reverse bias for cell 2 at $T=55^{\circ} \mathrm{C}$. The four curves are for $J_{L}=0,1.7,5.9$, and $23 \mathrm{~mA} / \mathrm{cm}^{2}$ with $\mathrm{G}$ (slope) increasing as $J_{L}$ increases.

Figure 12 slope dV/dJ of cell 2 at forward bias giving upper bound to series resistance. . . . . . . . .

Figure $13 \ln \left(J^{\prime}\right)$ vs $V-R_{s} J$ used to determine $A$ for cell 2, showing a single A factor at a given intensity and in the dark.

Figure $14 \mathrm{~A}$ factor at $J_{L}=0,1.7,5.9$, and $23 \mathrm{~mA} / \mathrm{cm}^{2}$ (from bottom at $\mathrm{T}=25^{\circ} \mathrm{C}$ ). Uncertainty in $\mathrm{A}$ is $\pm 0.05 . .26$

Figure $15 \mathrm{~V}_{\mathrm{oc}} \mathrm{vs.} \mathrm{T}$ for cell 1 showing $\phi=0.99 \mathrm{eV}$ at three intensities.

Figure $16 \mathrm{~J}$ 。 vs. $1 / \mathrm{T}$ for cell 1. Slope gives $\phi=0.99 \pm 0.02 \mathrm{eV}$ at all intensities. 
Figure 17 Current-voltage characteristics of a caTe/cas

device with a semitransparent $\mathrm{Cu} / \mathrm{Au}$. contact

before air heat treatment. . . . . . . . . 32

Figure 18 Q.E. measurements of a cdTe/Cas device with a semitransparent $\mathrm{Cu} / \mathrm{Au}$ contact before air heat treatment.

Figure 19 Current-voltage characteristics of a cdTe/Cds device with a semitransparent $\mathrm{Cu} / \mathrm{Au}$ contact after air heat treatment.

Figure 20 Q.E. measurements of a cdTe/CdS device with a semitransparent contact after air heat treatment. .

Figure 21 Spectral response in reverse bias normalized to zero bias.

Figure 22 Comparison of measured $\mathrm{J}$ to calculated from integrated spectral response. . . . . . . . 38

Figure 23 slope of $\mathrm{J}-\mathrm{V}$ curve (dJ/dV) (Dark $\mathrm{T}=301 \mathrm{~K}$ ). . . . . 39

Figure $24 \mathrm{~J}^{\prime}$ (corrected for shunt conductance) vs. V (Line is for $A=1.7$ ). . . . . . . . . . . .

Figure $25 \mathrm{~J}^{\prime}$ (corrected for shunt conductance and short circuit current) vs. V. (Line is for A-1.9). . . . 42

Figure $26 \mathrm{~V}_{o c}$ vs. Temperature (Intercept=1.35 ev). . . . . 44

Figure 27 Change in light generated current $\left(\delta J_{L}(V)=\right.$ difference between measured and predicted $J^{\prime}$ for $\left.A=1.9\right)$. . . . 45

Figure 28 Relative ratio of Cu/In ratio determined by EDS . . 49

Figure 29 SEM micrographs of Mo/In/Cu layer . . . . . . . . . 50

Figure 30 SEM micrograph of Mo/Te/In/Cu layer . . . . . . . 51

Figure 31 schematic of $\mathrm{H}_{2} \mathrm{Se}$ reaction system . . . . . . . . . 53

Figure 32 Normalized spectral response curve for a

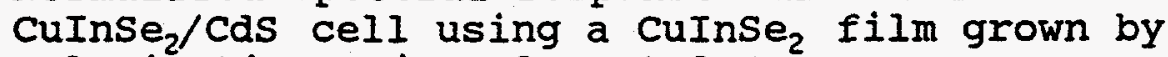
selenization using elemental $\mathrm{Se}^{2}$. . . . . . . 56

Figure 33 Schematic cross-section diagram of superstrate cate/cas device. 
page

Figure $34 \mathrm{XRD}$ scans before and after heat treatment at $400^{\circ} \mathrm{C}$ with $\mathrm{CdCl}_{2}$. The CdTe and cds thicknesses were

$2 \mu \mathrm{m}$ and $1 \mu \mathrm{m}$, respectively. . . . . . . . . 63

Figure 35 SEM photograph of the as-deposited CaTe surface. . 64

Figure 36 SEM photograph of the CaTe surface after heat treatment at $400^{\circ} \mathrm{C}$ with $\mathrm{CdCl}_{2}$. . . . . . . . . 65

Figure 37 Comparison of the caTe absorption edge in cdTe/CdS samples before and after heat treatment at $400^{\circ} \mathrm{C}$ with $\mathrm{CdCl}_{2}$. . . . . . . . . . . . . . . . 66

Figure 38 Normalized transmission, $T /(1-R)$, for $800 \AA$ thick CdS and spectral response of a CaTe/Cas device fabricated on the same cas sample. . . . . . . . . . . 68

Figure 39 Comparison of spectral response of caTe/Cas devices with different cas thicknesses. . . . . . . . . .

Figure 40 Normalized transmission, $T /(1-R)$, for $0.24 \mu \mathrm{m}$ thick CdS films heat treated at $400^{\circ} \mathrm{C}$ with different thicknesses of $\mathrm{CaCl}_{2}$. . . . . . . .

Figure 41 spectral response of caTe/Cds devices fabricated on the cas samples of Figure 40, having been heat treated with different thicknesses of $\mathrm{CaCl}_{2}$. . .

Figure 42 Quantum efficiency measurements (NREL) for caTe/Cds solar cells fabricated by various deposition methods (from reference 7): Photon Energy, Inc. (PE) - Spray Pyrolysis; Georgia Institute of Technology (GIT) - M.O.C.V.D.: Microchemistry, ITD (MC) - A.L.E.; University of South Florida (USF) - C.S.V.T.; Ametek Electron deposition.

Figure 43 Photon losses in CaTe/Cas solar cells . . . . . 76

Figure 44 spectral response of high efficiency caTe/Cds cells using evaporated cdTe and cds layers. Sample 40723.11 used cas which was heat treated at $400^{\circ} \mathrm{C}$ with $\mathrm{CdCl}_{2}$ prior to CdTe deposition. 
Table $1 \quad \phi$ and $A$ for the possible diode currents . . . . 13

Table 2 Cells Used for J-V Analysis . . . . . . . . 19

Table 3 Diode Parameters at $55^{\circ} \mathrm{C}$ and Different Intensities 25

Table 4 Comparison of cells showing that the difference in $v_{o c}$ is due to different barrier height. . . . 29

Table 5 Diode Parameters that are a Function of Temperature..................4 40

Table 6 Summary of I-V results for cuInse $/$ Cds cells using a cuInse, film grown by selenization with elemental $\mathrm{Se}$. . . . . . . . . . . .

Table 7 Summary of phases identified by XRD for $\mathrm{Cu} / \mathrm{In}$ layers selenized in elemental se and $\mathrm{H}_{2} \mathrm{Se}$ for temperatures from 150 to $400^{\circ} \mathrm{C}$........ 59

Table 8 XRD analysis of CdTe (111) peak before and after heat treatment at $400^{\circ} \mathrm{C}$ with $\mathrm{CdCl}_{2}$. The CaTe thickness was $2 \mu \mathrm{m}$. . . . . . . . . . . . 67

Table 9 Effect of restructuring thin $(0.24 \mu \mathrm{m})$ cds layers with $400^{\circ} \mathrm{C} \mathrm{CdCl}_{2}$ anneal prior to CdTe deposition $\cdot 73$

Table 10 NREL Test Results for Cells in Figure 44 . . . . 77

Table $11 \mathrm{~J}-\mathrm{V}$ device parameters for ITO/CdS/CdTe cells with different contacts. Measurements made under ELH illumination, normalized to $100 \mathrm{~mW} / \mathrm{cm}^{2}$ e $32^{\circ} \mathrm{C}$. . 
SECTION 1.0

INTRODUCTION

\subsection{BACKGROUND}

Modules utilizing copper-indium-selenide ( $\mathrm{CuInSe}_{2}$ ) and cadmium telluride (CdTe) have emerged as promising candidates for meeting the DOE long range efficiency, reliability and cost targets for flat plate photovoltaic energy systems (1).

Under the NREL Polycrystalline Thin-Film Task, the Institute of Energy Conversion (IEC) has been conducting an integrated program

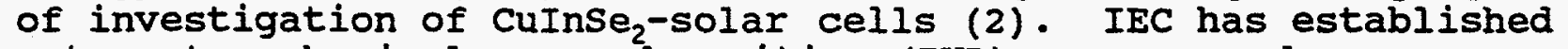
a two-step physical vapor deposition (PVD) process and characterization capabilities for fabricating and analyzing

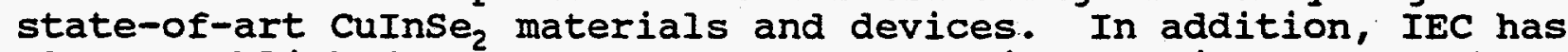
also established processes to produce device quality CuInse ${ }_{2}$ by the selenization of copper and indium layers with both $\mathrm{H}_{2} \mathrm{Se}$ and elemental Se.

IEC also initiated a chemical reaction engineering analysis of the formation of device quality CuInSe ${ }_{2}$ by selenization of copper and indium metal layers, a process which promises to be more readily translated from the laboratory scale solar cells to large area module manufacturing.

These results, along with those obtained by others under the NREL Polycrystalline Thin-Film Task indicate that further improvements in performance and cost potential of $\mathrm{CuInSe}_{2}$ modules can be expected from continued investigations of processing, material properties and device behavior.

Research conducted by IEC on CdTe has also shown that PVD is capable of producing near state-of-art cate materials and devices and that sequential post-deposition treatments are critical for achieving high efficiencies regardless of CdTe deposition

technique. Recent results obtained by IEC and others under the NREL Polycrystalline Thin-Film Task indicate that further research is likely to lead to achievement of practical

efficiencies greater than $15 \%$ and long term stability for thinfilm cdTe modules.

Accordingly, a continued research effort with the objective of obtaining the understanding of materials processing, properties and performance of polycrystalline thin-film solar cells needed to achieve the goals for performance, cost and reliability set by DOE for the National Photovoltaics Program is needed. A further objective of such a program is to support the development of competitive U.S. photovoltaic industry through collaboration with other research groups and the training of engineers and scientists in photovoltaic technology. 


\subsection{TECHNICAL APPROACH}

In order to achieve these objectives IEC has undertaken a phased three year program to carry out the following integrated research tasks:

\section{Task 1 - CuInse 2 Based Materials and Devices}

A. Characterize and optimize selenization of $\mathrm{Cu} / \mathrm{In}$ films with a primary goal of establishing capability to fabricate state-

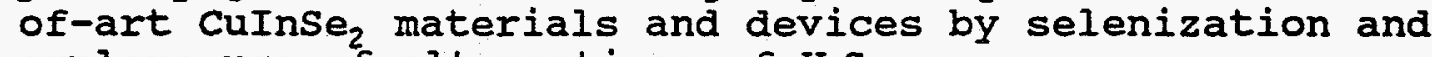
explore use of alternatives of $\mathrm{H}_{2} \mathrm{Se}$.

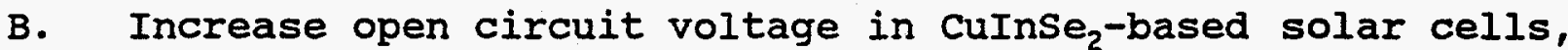
through investigations of reducing space charge recombination by alloying with gallium and/or sulfur and

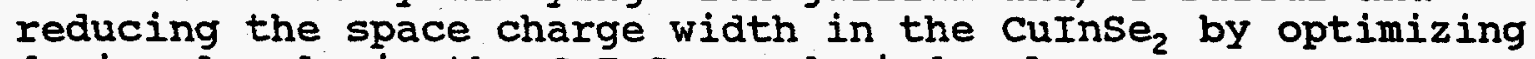
doping levels in the cuInse 2 and window layers.

c. Examine interface recombination as a limiting mechanism for open circuit voltage by fabricating and characterizing cuInse $_{2}$ heterojunctions with Znse, Zno, or other thin, ntype materials.

D. Identifying the controlling mechanisms and demonstrate approaches for improving open circuit voltage in superstrate cuInse 2 devices.

E. Quantify losses due to multidimensional junction effects and relate them to material processing and properties.

Task 2 - CaTe Based Materials and Device

A. Characterize and optimize fabrication of state-of-art caTe material and devices using physical vapor deposition to deposit caTe.

B. Develop and characterize thermally stable, transparent contacts to caTe.

c. Develop a quantitative model of the effects of sequential post-deposition processing, from systematic studies of the following relationships: $\mathrm{CdCl}_{2} / \mathrm{high}$ temperature heat treatment step and restructuring of caTe; contacting/low temperature heat treatment and type conversion of caTe: chemical treatments with bromine-methanol (or hydrazine).

D. Develop and optimize high transparency n-type window layer/heterojunction partners for increased short circuit current. Tin oxide and thin (<50 nm) CdS will be investigated for realizing short circuit currents in excess of $25 \mathrm{~mA} / \mathrm{cm}^{2}$. Other window layers, including $\mathrm{znCdS}$, will be 
used to study heterojunction interface mechanismis limiting open circuit voltage.

Task 3 - cuInse 2 and caTe cells with Thin Absorber Layers

A. Fabricate and cháracterize CuInse, solar cells with CuInse, absorber layers 1 micron or less in thickness and CdTe solar cells with cdTe absorber layers 0.3 micron or less in thickness. The effects of thin absorber layers on cell efficiency will be investigated. Losses in short circuit current, open circuit voltage and fill factor will be investigated. Losses in short circuit current, open circuit voltage and fill factor due to reduced thickness will be quantified with particular emphasis on recombination losses at ohmic contacts, optical losses due to decreased optical path length and shunts.

B. Develop and assess approaches for minimizing thicknessrelated losses, with particular emphasis on use of back surface reflection and texture to enhance optical absorption in thin cuInse $e_{2}$ and cate cells.

C. Fabricate and optimize the efficiency of thin absorber layer CuInSe, $_{2}$ and cdTe solar cells.

\subsection{OUTLINE OF REPORT}

In this report we describe the significant results and conclusions reached at the end of the second year of the program. Section 2 describes the work done in increasing our understanding as to how both the cuInse, and caTe thin film polycrystalline solar cells operate. Section 2.1 is devoted to describing how thin film polycrystalline heterojunction solar cells are designed to reduce minority carrier recombination at both the metallurgical interface and grain boundaries. Section 2.2 then describes the various modes of diode or junction behavior that are possible with these devices. Section 2.3 then reports on the $\mathrm{CuInSe}_{2}$ device measurements and analysis that determines the type of junction behavior. Section 2.4 reports on the caTe in the same fashion.

Section 3 is devoted to explaining how the materials that compose the devices are made and analyzed as well as the device fabrication steps for both CuInse, and CdTe solar cells. Section 3.1 covers the cuInse, cells with the emphasis on selenization techniques and section 3.2 is devoted to the processing of caTe devices. 
SECTION 2.0

DEVICE MODELING, CHARACTERIZATION AND ANALYSIS

\subsection{REQUIREMENTS OF A POLYCRYSTALLINE HETEROJUNCTION}

Analysis of thin film polycrystalline heterojunction solar cells explains how minority carrier recombination at the metallurgical interface and at grain boundaries can be greatly reduced by the proper doping of the window and absorber layers. When this is done, these devices exhibit the high quantum efficiencies and $J_{s c}$ 's measured in high efficiency CdTe and CuInse ${ }_{2}$ based solar cells. The analysis also shows that any quantitative modeling of these devices which relates the device performance to the bulk electronic properties of the material must consider the additional geometric dimension introduced by the polycrystalinity. Additional analysis and measurements show that the present solar cells are limited by the magnitude of the diode current which appears to be caused by recombination in the space charge region.

Various polycrystalline thin film configurations of the II-VI and I-III-VI compounds as well as their alloys, such as CdTe/CdS (3) and $\mathrm{Cu}(\mathrm{In}, \mathrm{Ga})(\mathrm{Se}, \mathrm{S})_{2} / \mathrm{CdS}(4-6)$, have been made into very promising photovoltaic devices. They are promising both because of the ease with which they can be manufactured and their rapidly improving efficiency. However, it sometimes appears as if the basic solar cell operating principles that have been developed and applied to photovoltaic devices made of silicon and the III-V compounds do not apply to the polycrystalline thin films. For example, even though these thin film devices are composed of polycrystalline grains with dimensions on the order of one micron and it appears as if no special care is taken to electrically passivate the grain boundaries, the recombination of minority carriers at the grain boundaries does not appear to be a problem. Also, although again it seems that no special care is taken to match lattices at the junctions, minority carrier recombination at the semiconductor interfaces does not seem to limit device performance. In spite of this puzzling behavior, we hope to show that polycrystalline thin film solar cells not only behave in the same manner as more familiar semiconducting photovoltaic devices; but, by understanding the similarities in operation to more familiar devices, many of the design and operating principles already learned by engineers and scientists can be applied to the thin film cells.

In order to understand how the problem of minority carrier recombination at the metallurgical interface is overcome, it will be helpful to look at the operation of a better understood heterostructure, the AlGaAs/GaAs solar cell. An energy band diagram of this device is shown in Figure 1 (7). The AlGaAs 


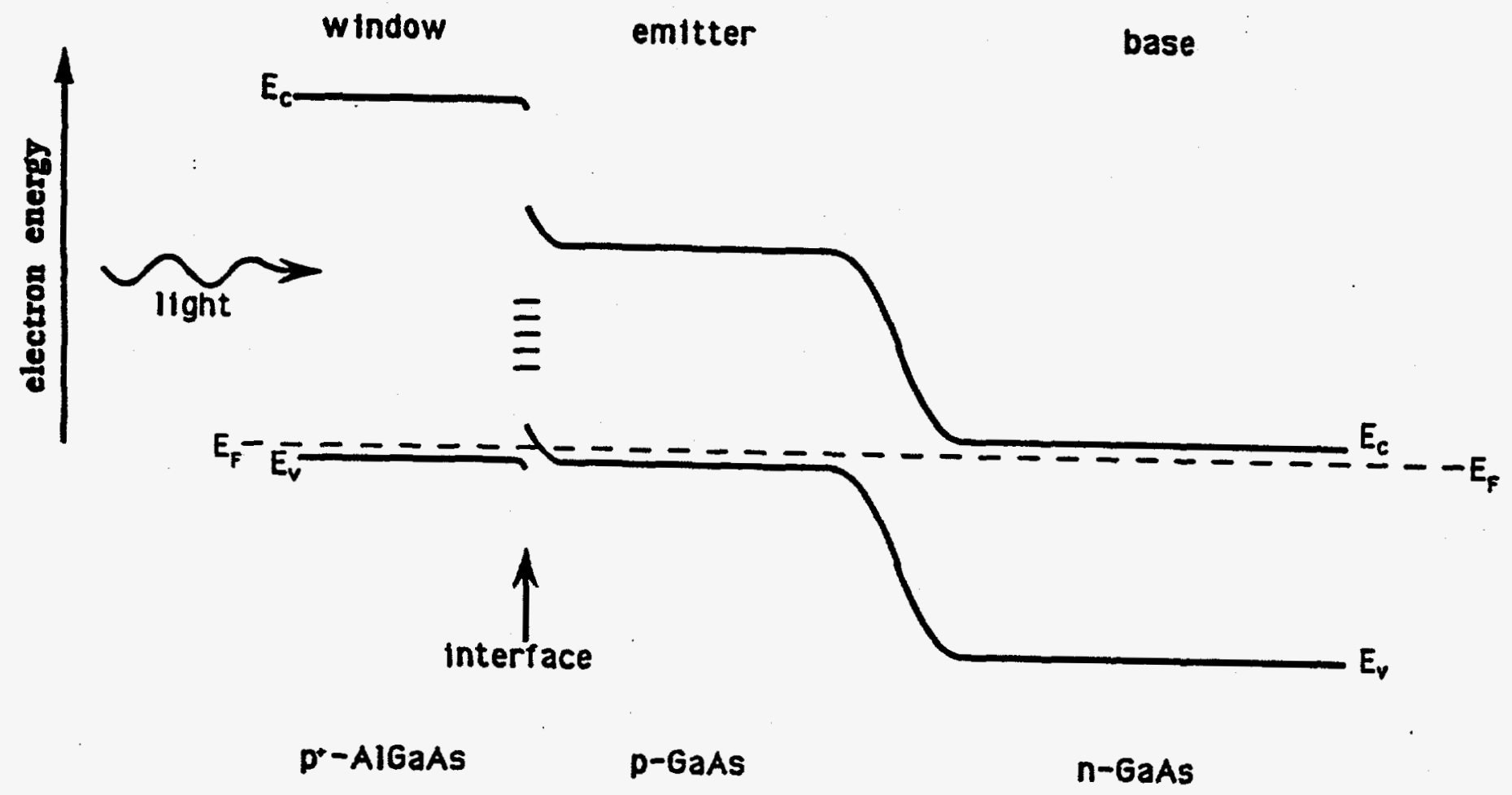

Figure 1. Energy band diagram of an AlGaAs/GaAs heteroface cell. 
window is added to reduce electron recombination at the surface of the p-type GaAs. The addition of the window layer has changed the problem of surface state recombination to one of interface recombination. It has also added another junction between the ptype AlGaAs and the p-type GaAs which, if made correctly, creates a potential barrier that prevents the electrons from reaching the interface states. In this case, the proper doping of the AlGaAs/GaAs heteroface structure has helped to reduce the electron recombination through midgap states at the metallurgical interface.

The AlGaAs/GaAs heteroface structure can then be converted to a heterojunction structure by shrinking the thickness of the emitter layer to zero as shown in Figure 2. Most of the change in electron potential occurs in the n-type GaAs because the effective acceptor concentration (or space charge density) in the p-type AlGaAs is much larger than the effective donor

concentration in the n-type GaAs. By removing the p-type emitter layer, a $\mathrm{p}-\mathrm{n}$, or actually a $\mathrm{p}^{+}-\mathrm{n}$, heterojunction has been made where minority carrier recombination at the metallurgical interface has been greatly reduced by using the built-in electron potential to prevent electrons from reaching the interface. This has been done without resorting to reducing the density of interface states by atomic lattice matching. This example demonstrates that, as long as the window layer of a $p-n$ or $n-p$ heterojunction (see Figure 3) has a sufficiently larger concentration of charge in the junction region, recombination of minority carriers, generated in the absorber layer, by the metallurgical interface will not be a problem. (Note that the base layer is now referred to as the absorber layer since it is the remaining active part of the photovoltaic device.)

In addition to explaining why thin film polycrystalline solar cells are not limited by minority carrier recombination at the interface, it is also necessary to show how these devices circumvent the difficulty of recombination at the grain boundaries. The devices that are being considered are assumed to have only columnar type grains in the thin film absorber, which would not impede carrier transport in the direction of carrier collection (see Figure 4) (8). Cross-sections of polycrystalline thin film photovoltaic devices appear to confirm this assumption. In looking at the band diagram of a grain perpendicular to the flow of carriers (see Figure 5), it is evident that the recombination of electrons can be strongly reduced by making the grain boundaries more p-type than the bulk. This is usually accomplished by treating the material after it is made. Because the treatment could preferentially affect the grain boundaries, its concentration, and hence its "doping" effect, could be larger at the grain boundaries as also shown in Figure 5 . Care must be taken in "doping" so that the maximum "effective" acceptor 


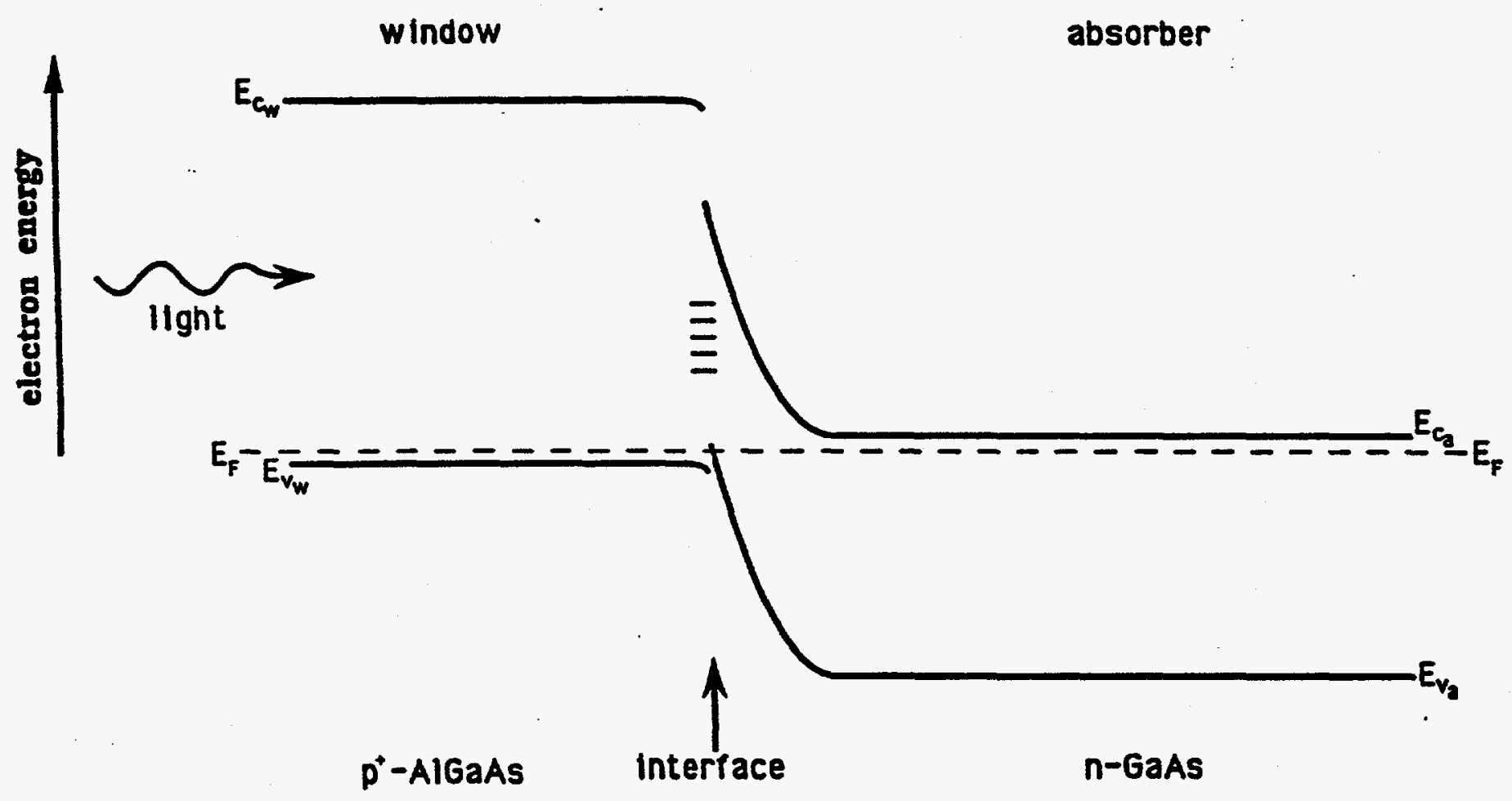

Figure 2. EnergY band diagram of an AlGaAs/GaAs heterojunction cell. 


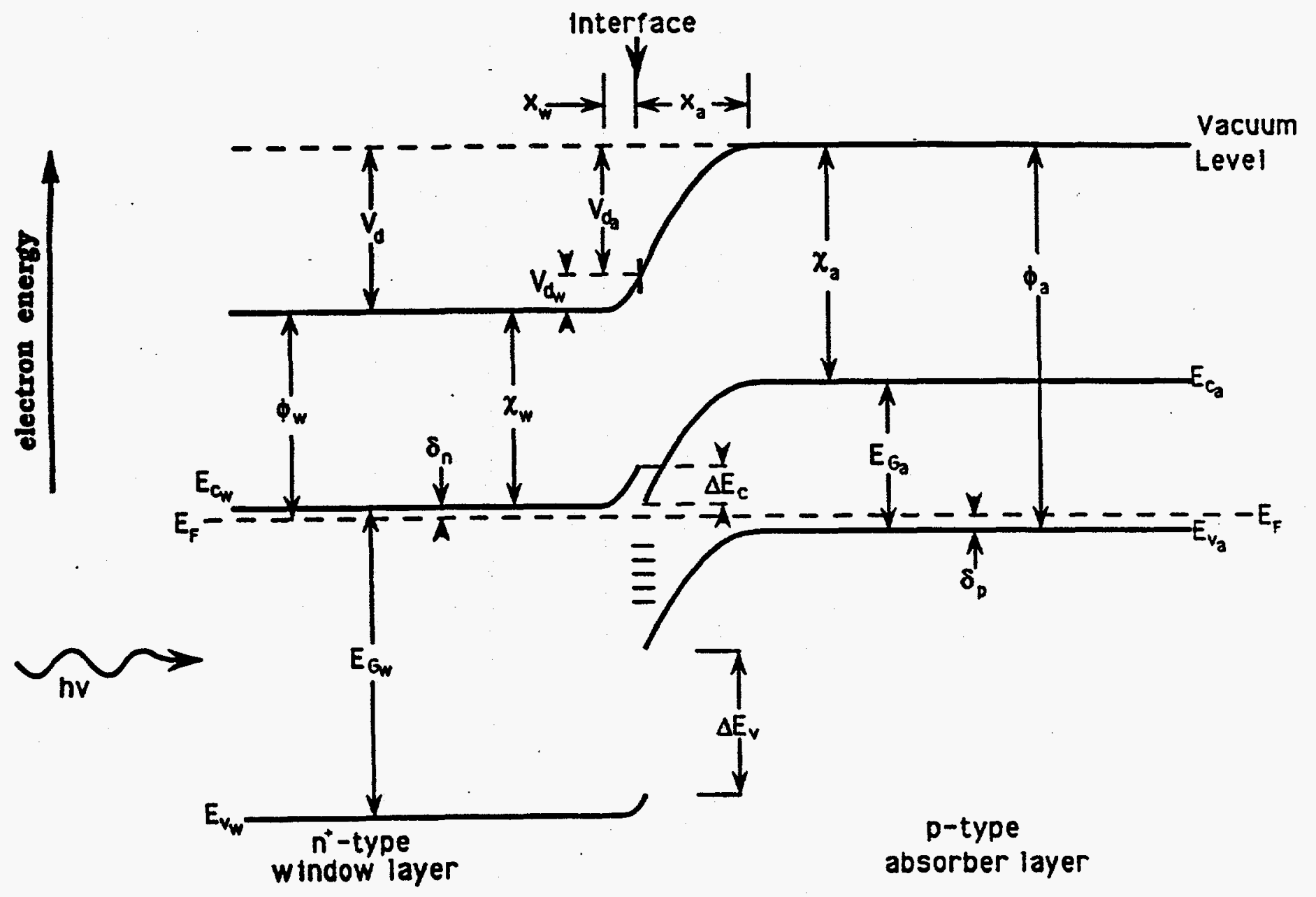

Figure 3. Energy band diagram of an $n-p$ heterojunction cell. 

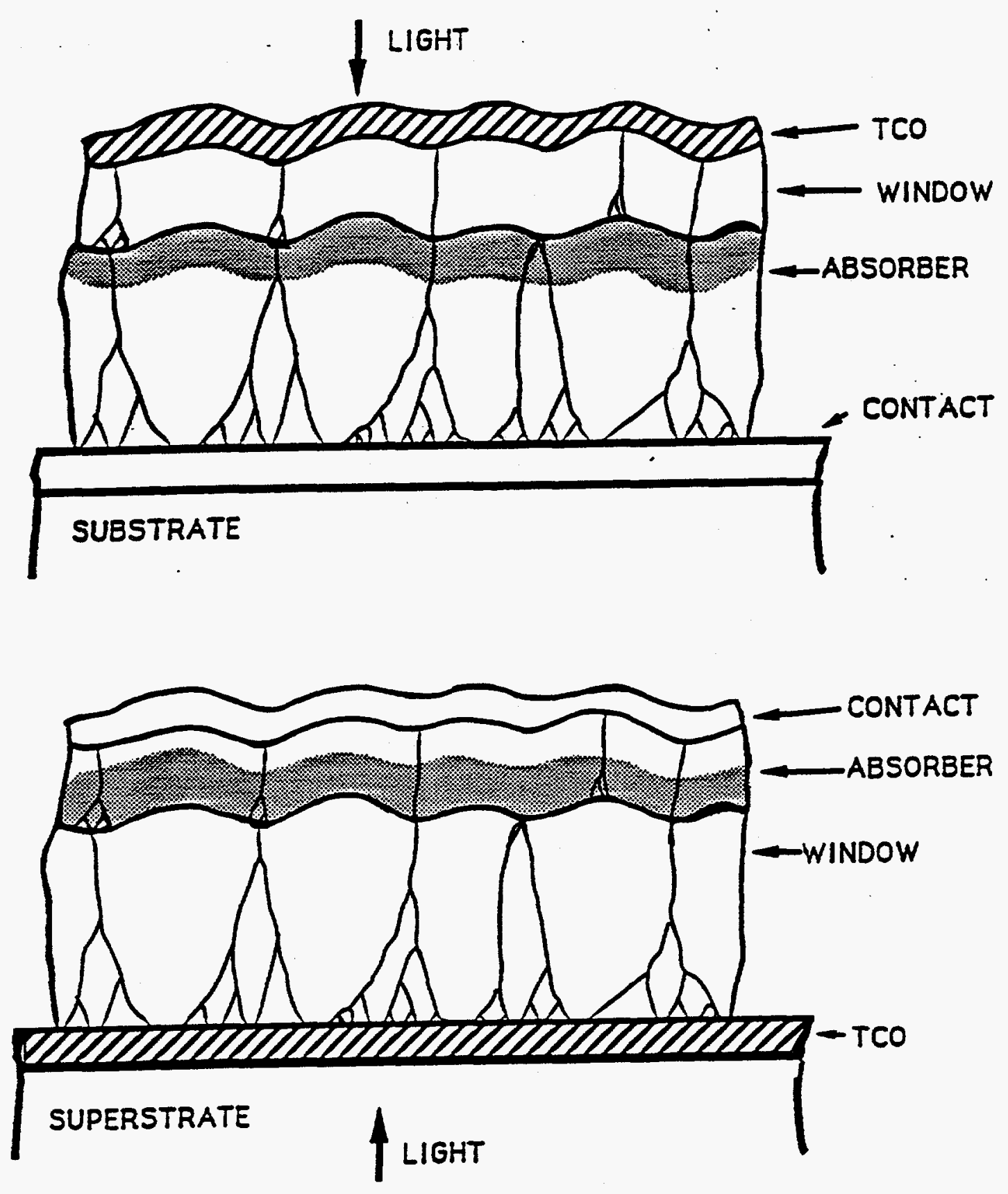

Figure 4. Cross section of a polycrystalline cell.

9 


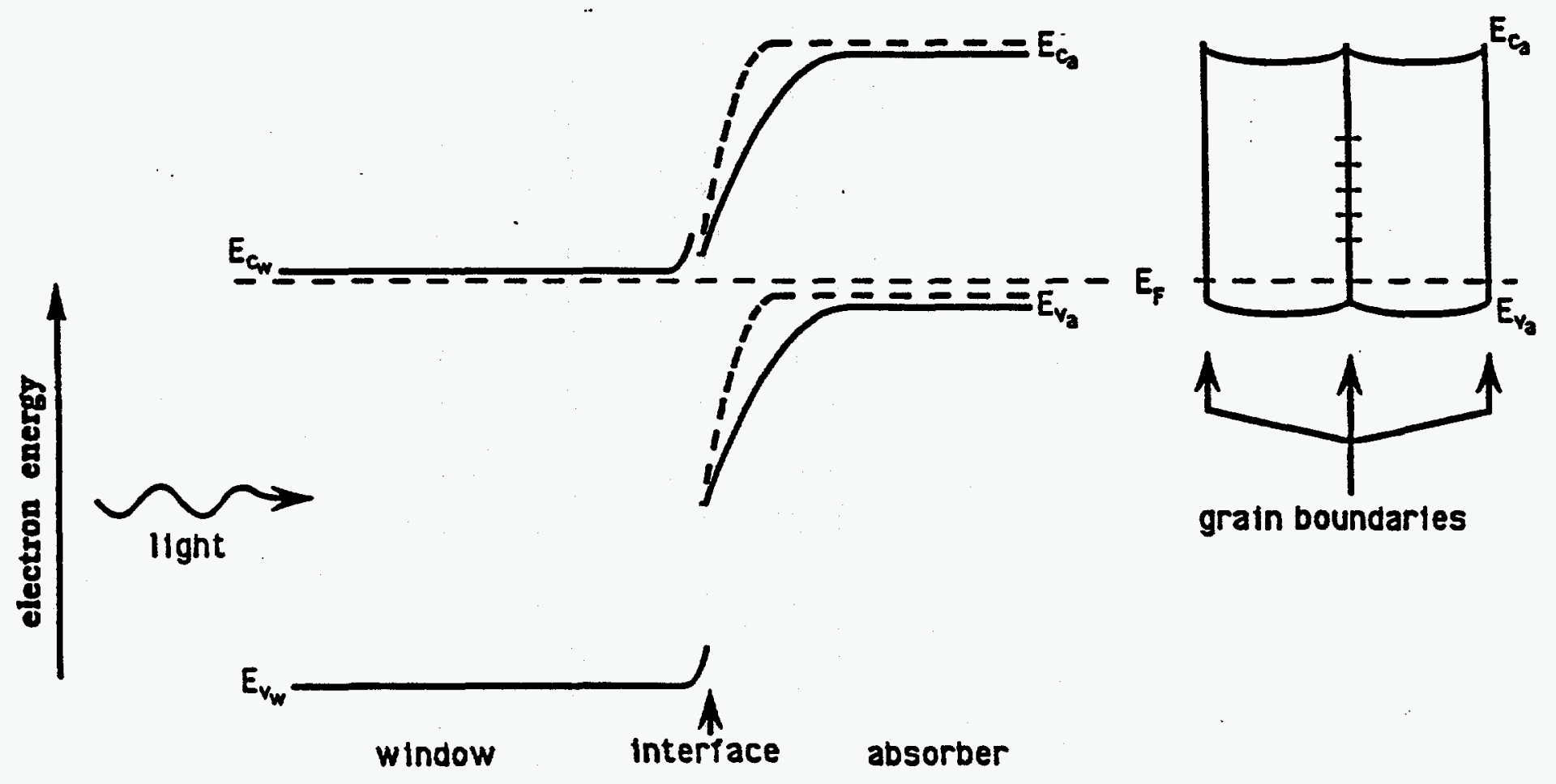

Figure 5. Energy band diagrams of polycrystalline grain boundaries. 
density at the grain boundary edges does not exceed the "effective" donor density in the window material, or the electrons will "see" the recombination states at the metallurgical interface. This reduction of grain boundary recombination only works for window-absorber heterojunctions because it depends on the current generating material being of only one carrier type (either $p$ or n-type). However, because of the inclusion of grain boundaries, care must be taken in modeling and analysis because the device is now two dimensional.

This discussion shows that it is possible to collect most of the carriers generated in the absorber layer of a thin film polycrystalline heterojunction solar cell. The difficulties of interface and grain boundary minority carrier losses can be reduced, at least in principle, by the controlled "doping" of the semiconductors and grain boundaries. Carrier or current collections are also aided by absorber materials that have large absorption coefficients. In this case the carriers are generated close to the metallurgical interface where they are collected.

\subsection{MODES OF OPERATION AND IIMITATIONS}

It is useful to examine a general type of $n-p$ heterojunction in order to determine the features necessary for good photovoltaic device operation. Figure 3 shows the band structures of an n-type window material and a p-type absorber. The subscripts (w) and (a) denote the window layer and absorber layer respectively. The previous example has already shown that the effective donor concentration of the window layer must be larger than the effective acceptor concentration of the absorber layer for good minority carrier collection (high $J_{s c}$ or $J_{L}$ ). To have a high efficiency solar cell, a high $V_{o c}$ is needed as well. To achieve this, the diode current of the heterojunction $\left(J_{D}\right)$ must be made as small as possible.

As shown in Figure 6 , the main contributions to $J_{0}$ come from the injected electron current, the recombination current in the space charge region, and the recombination current at the metallurgical interface. The form of the three currents can be expressed as $(9,10):$

$$
J_{D}=q v n=q v N e^{-q(\phi-v) / A k T}
$$

In this case, each of the currents has a different form for carrier "velocity" ( $v)$, barrier height, $(\phi)$, and diode quality factor (A) as shown in Table 1. Note that all the parameters shown are only "effective" parameters "averaged" over the grain boundaries. The largest of these currents will control $J_{D}$ and hence the $V_{o c}$ of the device. The differences in $A$ and $\phi$ enable one to determine which of the current mechanisms is controlling $J_{D}$ by measuring $J_{D}$ as a function of temperature ( $T$ ) and voltage 


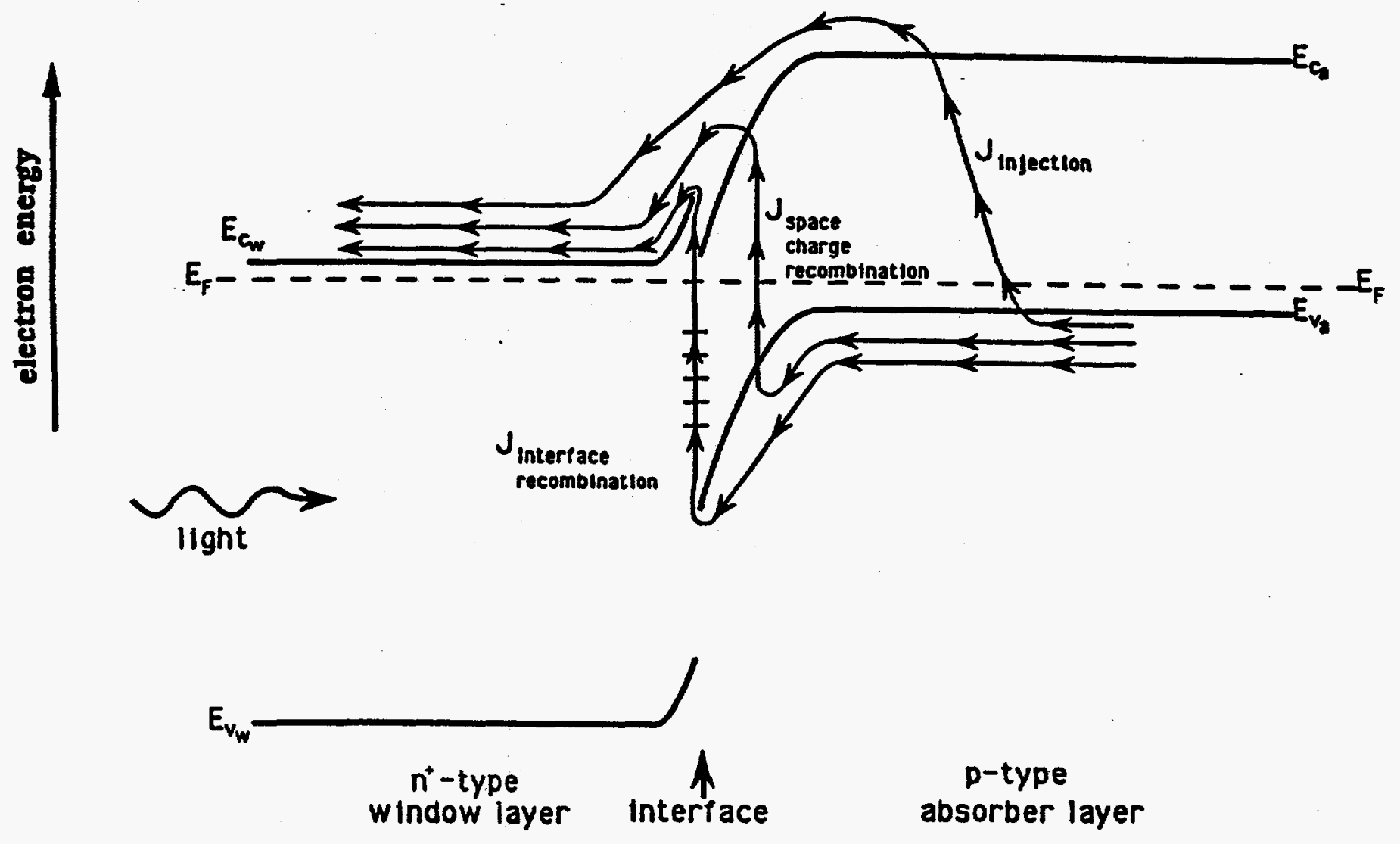

Figure 6. Energy band schematic of the diode current in a heterojunction cell. 
Table 1. $\phi$ and $A$ for the possible diode currents.

$\begin{array}{lll}J_{0} & \phi\end{array}$

diode current barrier height type

Injection

space charge

recombination

interface

recombination
$E_{g}-\delta n-\delta p-\Delta E_{c}$

$\mathbf{E}_{\mathbf{g}}$

$E_{g}=\delta n-\Delta E_{c}$
$\leq E_{g}$ diode quality factor

1

$1-2$

1

(V). The barrier height can usually be found by measuring $\mathrm{V}_{\text {oc }}$ as a function of temperature since:

$$
\mathrm{v}_{o c}=\phi+(A k T / q) \ln \left(J_{L} / q v N\right)
$$

With $\mathrm{CuInSe}_{2} / \mathrm{CdS}$ solar cells, current-voltage measurements made as a function of temperature yield diode quality factors in the range from about 1.5 to 2.0 with barrier heights near $1 \mathrm{eV}$, the bandgap of the CuInSe $e_{2}$ absorber (11-14). Additional measurements made on solar cells where the bandgap of the CuInSe absorber is $^{2}$ increased with the addition of $\mathrm{Ga}$, show the barrier height changing with the bandgap of the absorber (13). However, almost no change in barrier height is seen when the bandgap of the cds window material is increased with the addition of $\mathrm{zn}(12,13)$. These measurements indicate that the mechanism controlling the diode current is recombination in the space charge region of the $\mathrm{CuInSe}_{2}$.

Fewer high efficiency cdTe/Cds devices have been measured and

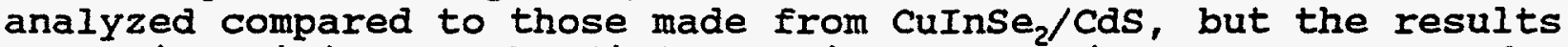
are quite similar. The diode quality factor is between 1.5 and 2.0 , but with a barrier height of $1.35 \mathrm{eV}$ (15). The barrier height value of $1.35 \mathrm{eV}$ is about $0.1 \mathrm{eV}$ less than the bandgap of cdTe. However, other measurements of the device indicate that the bandgap of the CdTe is reduced near the metallurgical interface due to the interdiffusion of $\mathrm{Te}$ and $S(16,17)$. Thus, the diode current of the CdTe/CdS solar cell is also apparently controlled by recombination in the space charge region of the cdTe.

Some of the one dimensional numerical modeling of the currentvoltage behavior of $\mathrm{CuInSe}_{2} / \mathrm{CdS}$ and $\mathrm{CdTe} / \mathrm{CdS}$ devices have also arrived at similar conclusions $(18,19)$. However, the failure to 
take into account the effects of the grain boundaries makes the electronic properties used in the modeling only "averaged"

values.

The effect of interface recombination on the light generated current in a thin film heterojunction solar cell can be reduced by making sure that most of the junction built-in voltage (or diffusion voltage) is across the absorber layer at the interface.

The loss of minority carriers to grain boundary recombination in the polycrystalline absorber can be reduced if the grain boundary edges are more heavily goped than the bulk.

Because of the two dimensional problem created by the grain boundaries, simple one dimensional modeling will only give "averaged" values for the electronic properties of the absorber.

From current-voltage measurements, it appears that recombination in the space charge region of the absorber controls the diode current during solar cell operation.

\subsection{CuInSe $_{2} /(\mathrm{CdZn}) \mathrm{S}$ DEVICE OPERATION}

Analysis of CuInse, /Cas cells by several groups has shown previously that $V_{o c}$ is primarily limited by shockley-Read-Hall (SRH) recombination in the cuInse $(11,12,18)$. A standard diode equation is normally used to describe the cell operation:

$J=J_{0}\left\{\exp \left[q\left(V-R_{s} J\right) / A K T\right]-1\right\}-J_{L}+G V$

with,

$J_{0}=J_{00} \exp \left(-q E_{a} / k T\right)$

The diode quality factor, $A$, has been found to be 1.5-2.0 for CuInSe 2 with $J_{0} \sim 10^{-3}-10^{-5} \mathrm{~mA} / \mathrm{cm}^{2}$. At $\mathrm{J}=0$,

$\mathrm{V}_{o c}=A E_{a}+(A k T / q) \ln \left(J_{L} / J_{o o}\right)$

so measurements of $\mathrm{V}_{\text {oc }}$ versus temperature extrapolated to $\mathrm{T}=0$ give the product $\mathrm{AE}_{\mathrm{a}}$. This is found to equal $0.9-1.0 \mathrm{eV}$, the CuInse, bandgap, for the range of $A$ factors observed. Therefore, the activation energy is written $E_{a}=\phi / A$ with $\phi \sim 1.0 \mathrm{eV}$ the barrier height for recombination. $V_{o c}$ and $\phi$ do not increase as the bandgap of the window layer is increased by adding $\mathrm{zn}$ to the cds, indicating that the recombination takes place in the cuInSe $_{2}$ (12) and not at the cuInse $/(\mathrm{Cdzn}) \mathrm{s}$ interface.

While considerable progress has been made in determining the

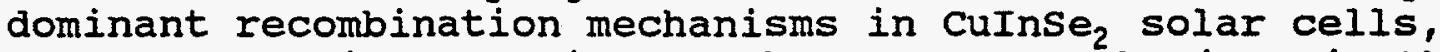
several questions remain and the current mechanisms in the device 
need to be better understood to enable further increases in $\mathrm{V}_{o c}$. Detailed analysis of the current voltage characteristics as a function of temperature and light intensity has been used to investigate the role of different diode recombination mechanisms.

\subsubsection{Heterojunction and Interface Effects}

The role of recombination at the CuInse $/$ Cas interface is not established. It is expected that interface recombination will result in the diode obeying eqn. 3 with $A=1$. The lack of lattice matching in this and other thin film heterojunction cells should give a high density of interface recombination states so the interface recombination will be limited only by the supply of holes to the interface. The interface, then, should behave as a metal-semiconductor junction so the Richardson constant gives $J_{0}$ $\sim 10^{10} \mathrm{~mA} / \mathrm{cm}^{2}$ (19). This will limit $\mathrm{V}_{\text {oc }}$ for cuInse, cells to $\sim 0.52 \mathrm{~V}$ unless the density of interface states is reduced significantly or the bandgap of the $\mathrm{CuInSe}_{2}$ is increased near the interface.

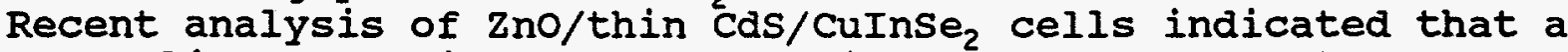
tunnelling mechanism must be considered as well as the SRH recombination to describe the temperature dependence of the dark $\mathrm{J}-\mathrm{V}$ data (20). Finally, it is not known what the light intensity dependence of the diode characteristics is and to what extent, if any, superposition of light to dark $J-V$ characteristics holds.

Analysis of $J-V$ data will be used to determine $A$ and whether the device is controlled by more than one current mechanism. Figure 7 shows $\ln (J)$ vs $V$ calculated for $S R H$ (with $A=1.7, J_{00}=10^{6} \mathrm{~mA} / \mathrm{cm}^{2}$,

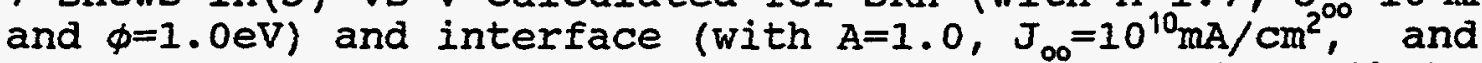
$\phi=0.95 \mathrm{eV}$ ) currents. The sum of these currents shows that a contribution from interface recombination should be evident from the J-V analysis which can be used to determine whether the device is controlled by more than one current mechanism.

The A factor gives an upper limit to the fill factor which is calculated from equation 3 with $R_{s}=G=0$ for 3 values of $V_{\text {oc }}$ at $25^{\circ} \mathrm{C}$ and shown in Figure 8. With $v_{o c}=0.45 \mathrm{~V}, A=2$ limits the fill factor to $<66.7 \%$. Therefore, cells with higher fill factors will have a lower value of $A$ and may show evidence of interface recombination with $\mathrm{A}=1$.

\subsubsection{I-V Analysis}

Three methods of analysis are used to determine the diode parameters from $\mathrm{J}-\mathrm{V}$ data as a function of temperature and light intensity: 


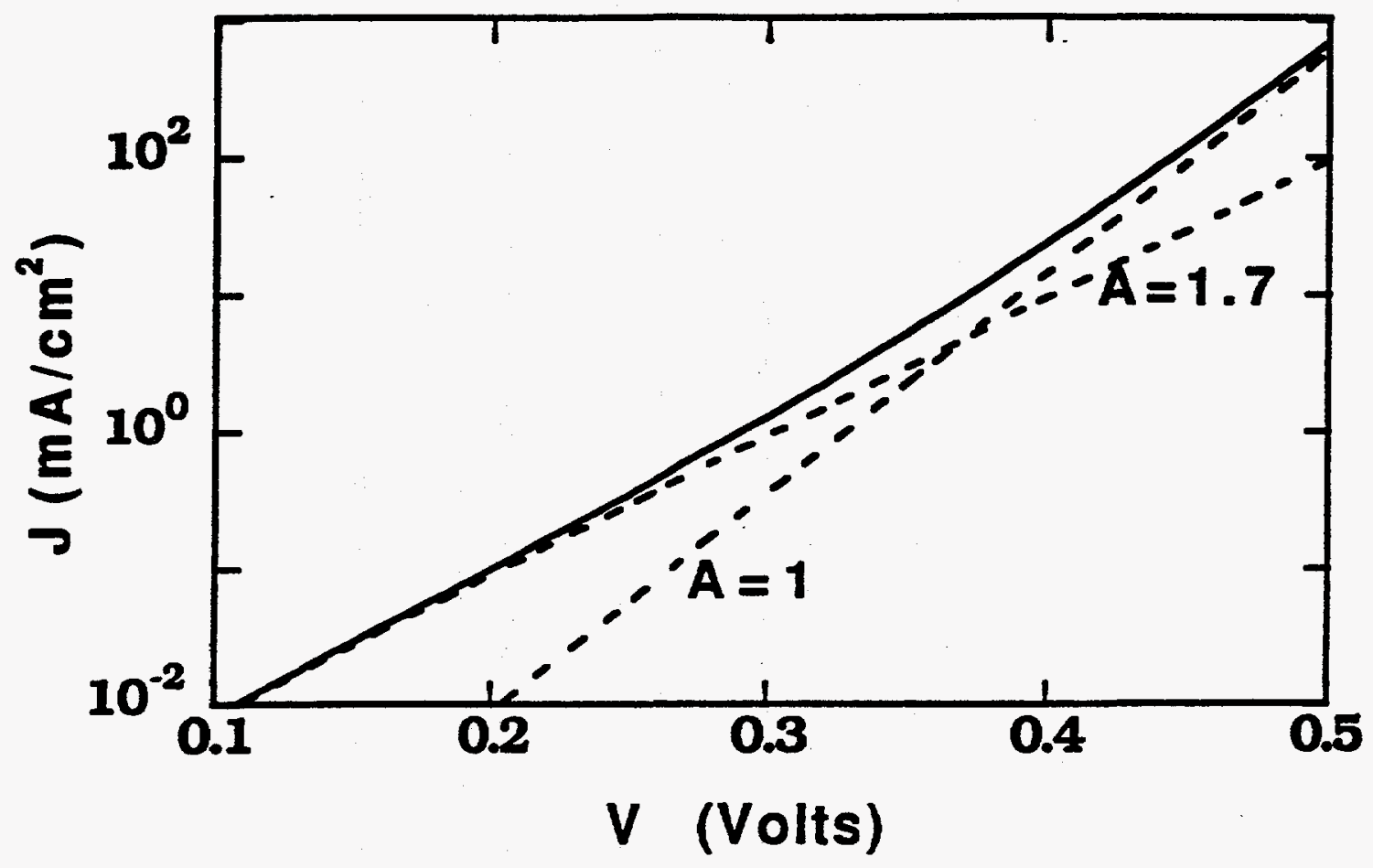

Figure 7. Model of currents controlled by $S R H(A=1.7)$ and interface $(A=1)$ recombination and their sum. 


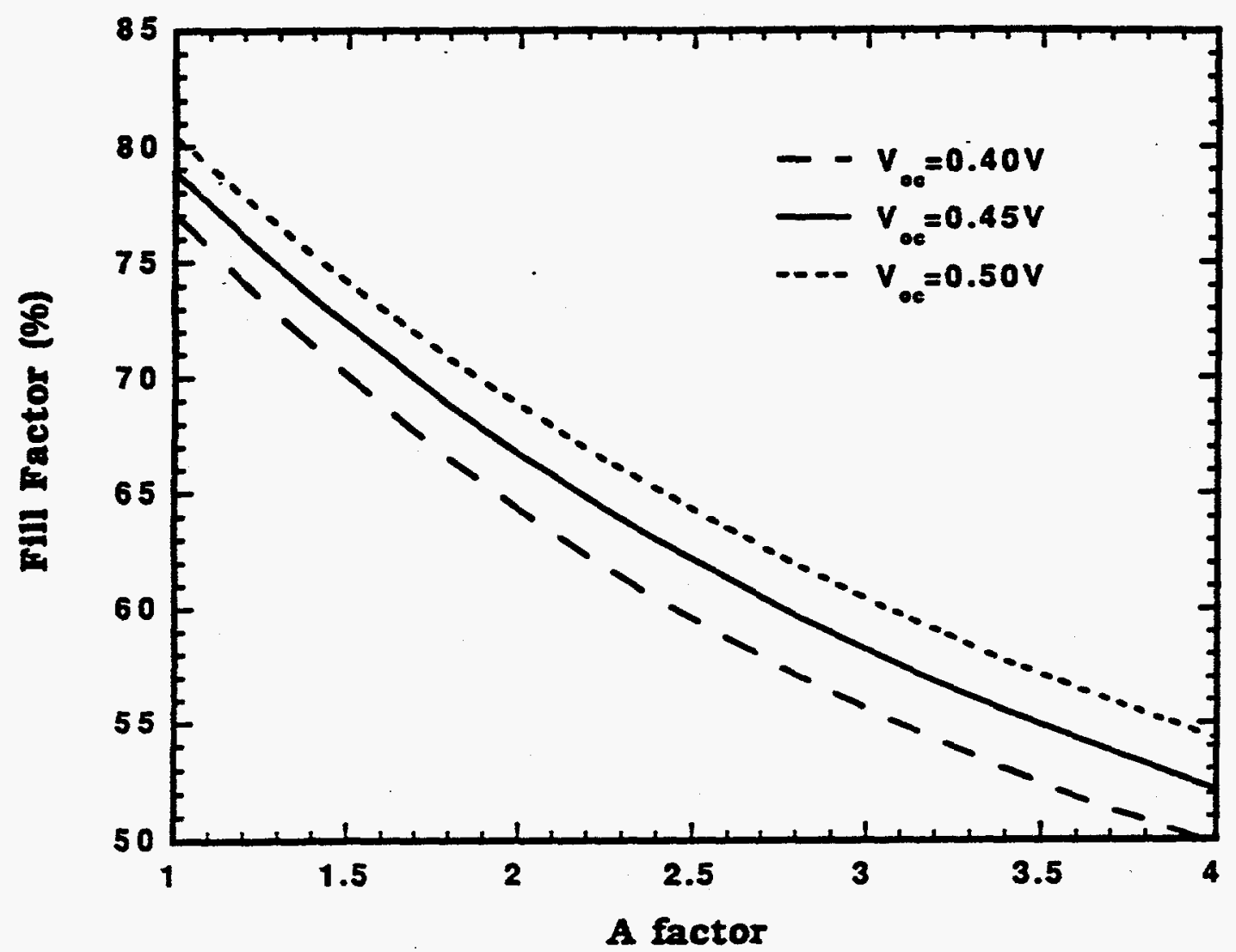

Figure 8. Fill factor calculated from standard diode equation 3 with no resistance or shunt losses at $T=25^{\circ} \mathrm{C}$. 
1) The barrier height, $\phi$, is determined from the intercept of $V_{o c}$ versus temperature according to eqn. 5. Data at different intensities shows that $\phi$ is independent of light intensity (2).

2) The diode factor, $A$, and prefactor, $J_{0}$, are determined from the $J-V$ data at a given temperature and intensity according to eqn. 3. In this work $G$ is first determined by a linear fit to the data at reverse bias. Then an upper bound on the series resistance is determined from dV/dJ in forward bias. Finally, defining $J^{\prime}=J-J_{L}+G V$, a fit of $\ln \left(J^{\prime}\right)$ vs $V-R_{s} J$ is done to determine $\dot{A}, J_{0}$, and $R_{s}$. Other methods are used to fit the data to eqn. 3 , including non-linear least squares fitting procedures. In any case, it is critical to evaluate the temperature dependence of this analysis to determine if the form of the temperature dependence is sufficient. In particular, the $A$ factor is defined as a constant.

3) Measurements of $J_{s c}$ and $V_{o c}$ at fixed temperature and varying light intensity are used to determine the diode parameters $A$ and $J_{o}$. The slope of $l n\left(J_{s c}\right)$ vs $V_{o c}$ is $q / A k T$ if a shunt term is neglected and $J_{0}$ and $A$ have no intensity dependence according to eqn. 3 , with $J_{s c} \approx J_{1}$. Again this analysis should give a constant value of $A$ at all temperatures. Previous results of this analysis (2) showed curvature in the intensity variation in $A$ for cuInse $/$ (CdZn)s cells which was attributed to either an admixture of interface and SRH recombination terms or a voltage dependent $A$ factor. However, as will be shown below, $G$ and $J_{0}$ have an intensity dependence which causes the curvature in the $J_{s c}-V_{o c}$ data so the result for $A$ is not correct.

The cells used in this work had evaporated CuInse, and (CdZn) S:In layers. The cells were fabricated with $2 \mu \mathrm{m}$ Mo sputtered onto 7059 glass, then a $2 \mu \mathrm{m}$ CuInSe $_{2}$ layer was deposited followed by a $1.5 \mu \mathrm{m}$ (CdZn) S layer with $10 \% \mathrm{Zn}$ and sheet resistance $-35 \Omega / \square$. The top contact had a $0.2 \mu \mathrm{m}$ sputtered ITO layer with $\mathrm{Ni}$ contacts. Cells were defined by photolithography with area $=0.08 \mathrm{~cm}^{2}$.

Two cells were measured and their J-V characteristics under AMI.5 illumination at $25^{\circ} \mathrm{C}$ are listed in Table 2. The cells both had fill factors $>67 \%$ and the only significant difference in the two cells was $V_{\text {oc }}$ with the difference $24 \mathrm{mV}$ at $25^{\circ} \mathrm{C}$. The results will be compared to determine the cause of this difference. 
Table 2 Cells Used for $J-V$ Analysis

$\begin{array}{cccccc}\text { Cel1 \# } & \begin{array}{r}\text { CuInSe } \\ \text { run \# }\end{array} & \begin{array}{l}V_{\text {oc }} \\ (V)\end{array} & \begin{array}{c}J_{s c} \\ \left(\mathrm{~mA}^{2} / \mathrm{cm}^{2}\right)\end{array} & \begin{array}{c}F F \\ (\%)\end{array} & \begin{array}{c}\text { Eff. } \\ (\%)\end{array} \\ 1 & 32187.22 & 0.440 & 33.8 & 67.6 & 10.1 \\ 2 & 32220.22 & 0.417 & 33.3 & 67.2 & 9.3\end{array}$

$J-V$ measurements were made in the dark and at 3 intensities, up to $-60 \mathrm{~mW} / \mathrm{cm}^{2}$, under $\mathrm{ELH}$. illumination. The temperature ranged from -28 to $85^{\circ} \mathrm{C}$.

The J-V curves at 4 temperatures for cell 2 are shown in Fig. 9. At the lowest temperature a contribution due to a back diode is clearly evident in forward bias. This back diode, which has been discussed previously (21), does not affect $v_{\text {oc }}$ but prevents analysis of the $\mathrm{J}-\mathrm{V}$ curve to determine the diode parameters. Thus analysis is restricted to $\mathrm{T}>25^{\circ} \mathrm{C}$ for cell 2 and $\mathrm{T}>10^{\circ} \mathrm{C}$ for cell 1. Attempts to fit the $\mathrm{J}-\mathrm{V}$ curve to eqn. 3 when there is even a small contribution from this back diode will give a lower A factor to compensate for the increased $R_{s}$ needed to fit the forward bias data.

The J-V curves at 4 intensities and $T=55^{\circ} \mathrm{C}$ are replotted on a $\mathrm{log}$ scale in Fig. 10. Procedure 2 above was used to analyze the data with the results for sample 2 given in Table 3 . The values of $G$ and $J_{1}$ were determined as shown in Fig. 11. G increases from 0.05 to $0.5 \mathrm{~ms} / \mathrm{cm}^{2}$ as $J_{1}$ increased from 0 to $23 \mathrm{~mA} / \mathrm{cm}^{2}$. At the highest intensity, $J_{L}$ differed from $J_{s c}$ by only $1 \%$. A bound on the series resistance of $<1 \Omega-\mathrm{cm}^{2}$ was determined from the derivative dV/dJ in forward bias shown in Fig. 12. In this case there is only a small intensity dependence with $R_{s}$ decreasing as the intensity increases, probably due to photoconductivity of the $(\mathrm{CdZn}) \mathrm{S}$. Finally, $\ln \left(\mathrm{J}^{\prime}\right)$ vs $\mathrm{V}-\mathrm{R}_{\mathrm{s}}$ is shown in $\mathrm{Fig} .13$ at $\mathrm{T}=55^{\circ} \mathrm{C}$ for $J_{L}=0$ and $23 \mathrm{~mA} / \mathrm{cm}^{2}$ where the lines have slope $q / A k T . R_{s}$ is determined to give the best fit at far forward bias. The difference between $J^{\prime}$ and the fit at $10 \mathrm{w}$ current is $-0.2 \mathrm{~mA} / \mathrm{cm}^{2}$ at $0.1 \mathrm{~V}$ for $J_{L}=23 \mathrm{~mA} / \mathrm{cm}^{2}$ and $<0.1 \mathrm{~mA} / \mathrm{cm}^{2}$ for $J_{L}=5.9 \mathrm{~mA} / \mathrm{cm}^{2}$ This discrepancy is probably due to a voltage dependent $J_{L}$ but, because it is small, it has not been verified by spectral response measurements.

The results of this procedure, given in Table 3 , show that, for cell 2, $A=1.5$ and is constant for $J_{L}<6 \mathrm{~mA} / \mathrm{cm}^{2}$ but increases to 1.75 at $23 \mathrm{~mA} / \mathrm{cm}^{2}$. Similarly, $J_{0}$ increases at the highest intensity. The results for cell 1 show similar results with $A=1.6$ for $J_{L}<6 \mathrm{~mA} / \mathrm{cm}^{2}$ and also increasing to 1.75 at $23 \mathrm{~mA} / \mathrm{cm}^{2}$. all cases there is no change at higher currents to $A-1$ which 


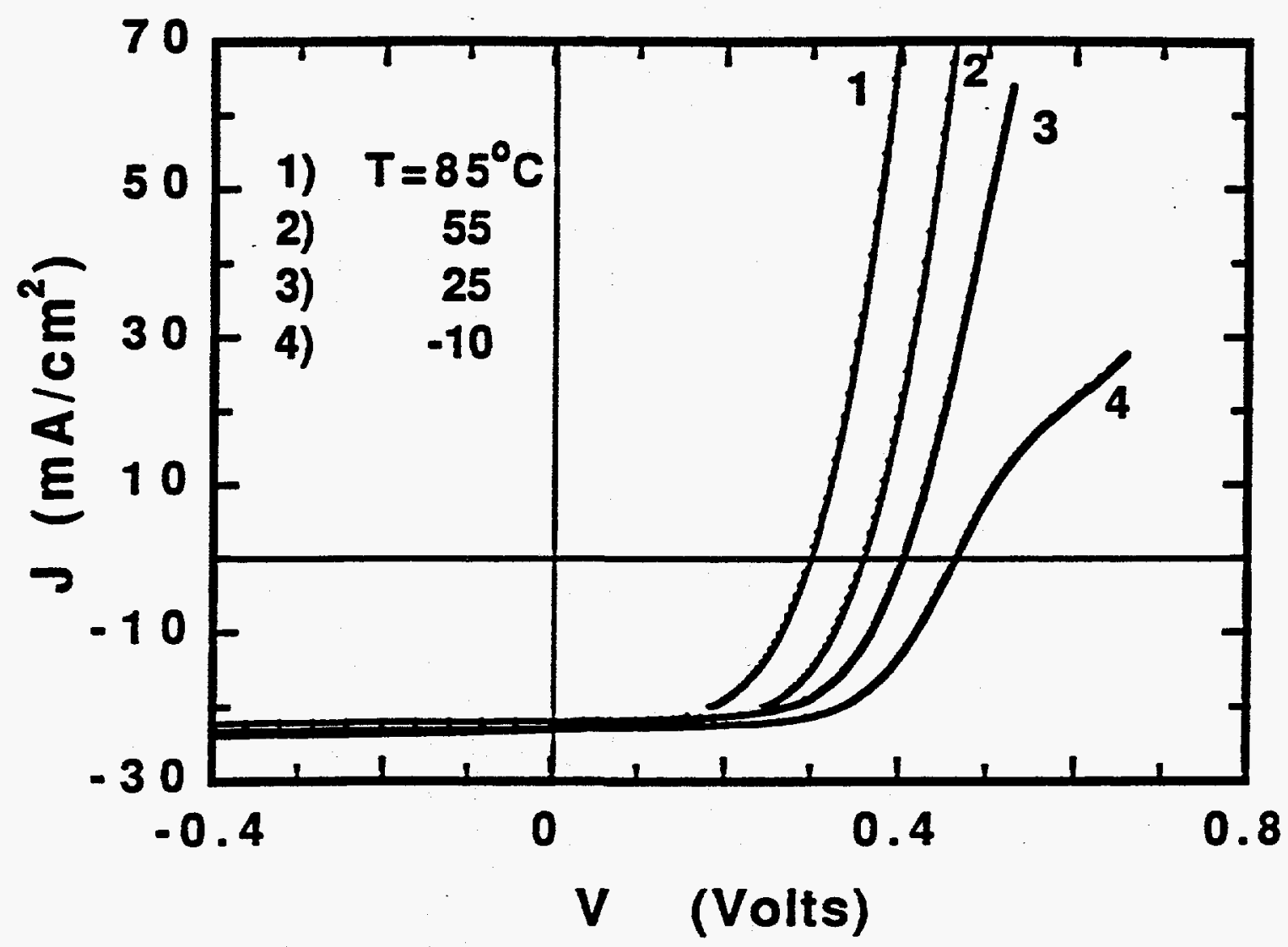

Figure 9. J-V curves of cell 2 at four temperatures. A back diode is seen at forward bias for $\mathrm{T}<25^{\circ} \mathrm{C}$. 


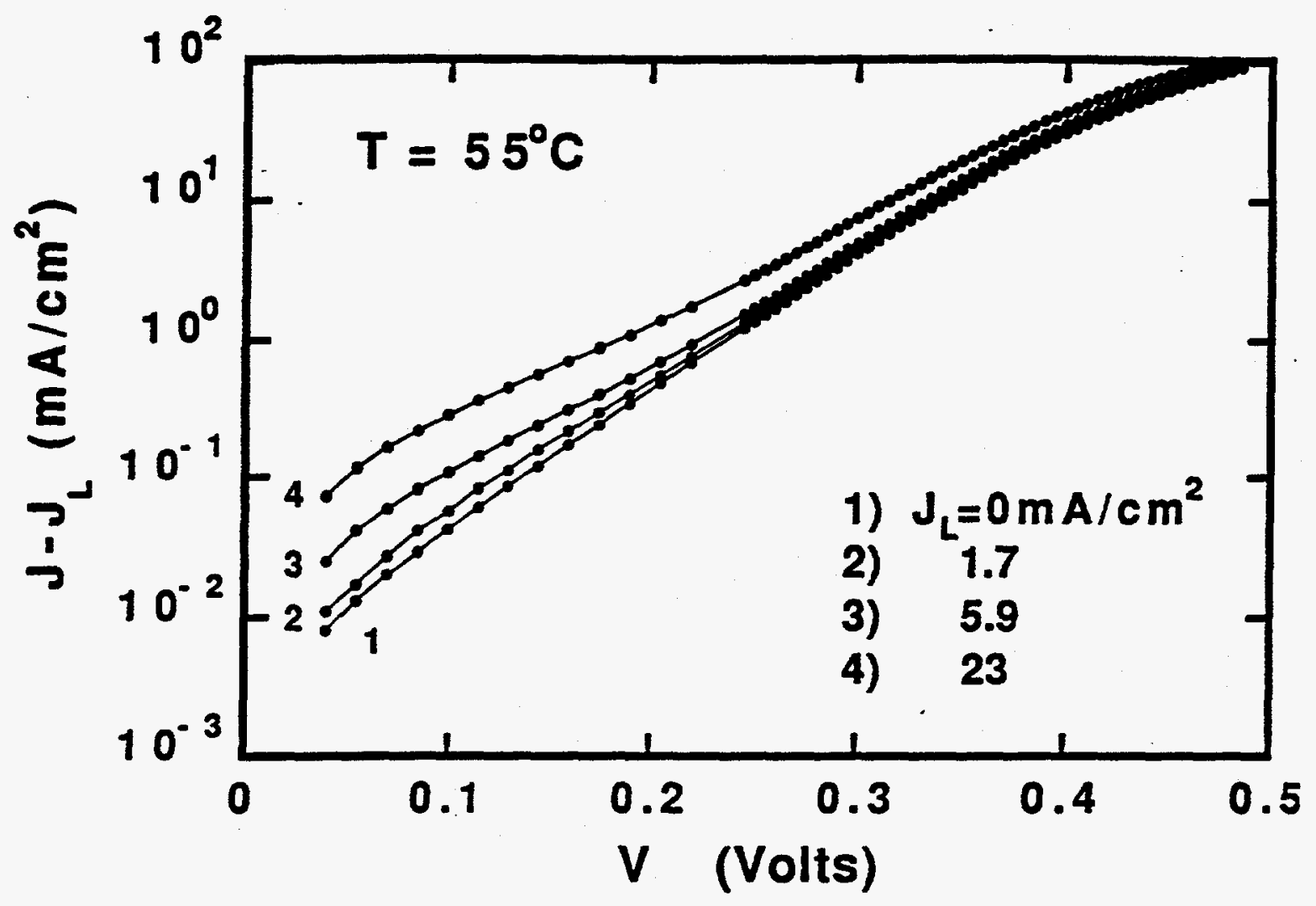

Figure 10. $\ln (\mathrm{J})-\mathrm{V}$ of $\mathrm{cell} 2$ at $\mathrm{T}=55^{\circ} \mathrm{C}$ and four intensities. 


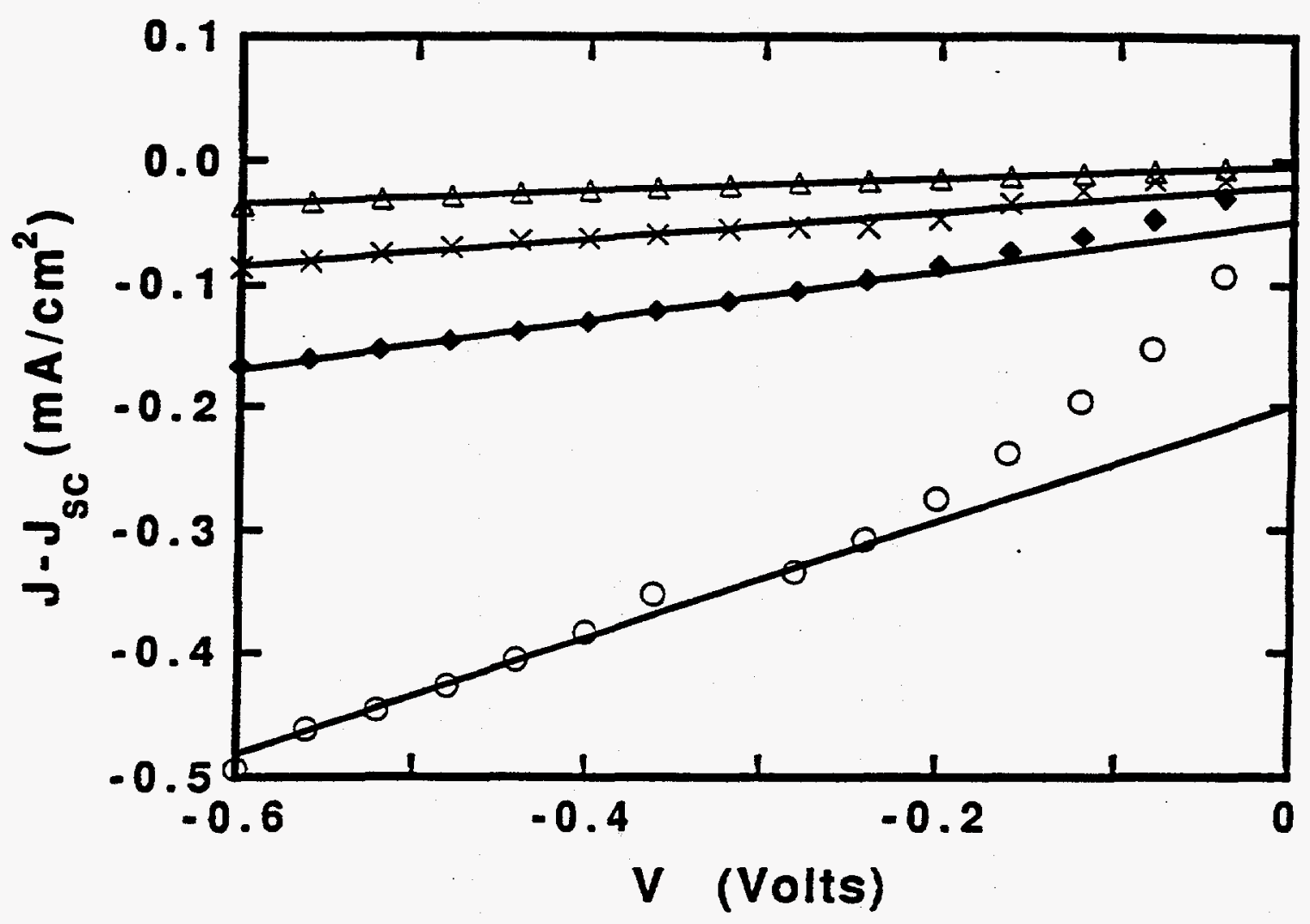

Figure 11. Determination of $G$ at reverse bias for cell 2 at $T=55^{\circ} \mathrm{C}$. The four curves are for $J_{L}=0,1.7,5.9$, and $23 \mathrm{~mA} / \mathrm{cm}^{2}$ with $G$ (slope) increasing as $J_{L}$ increases. 


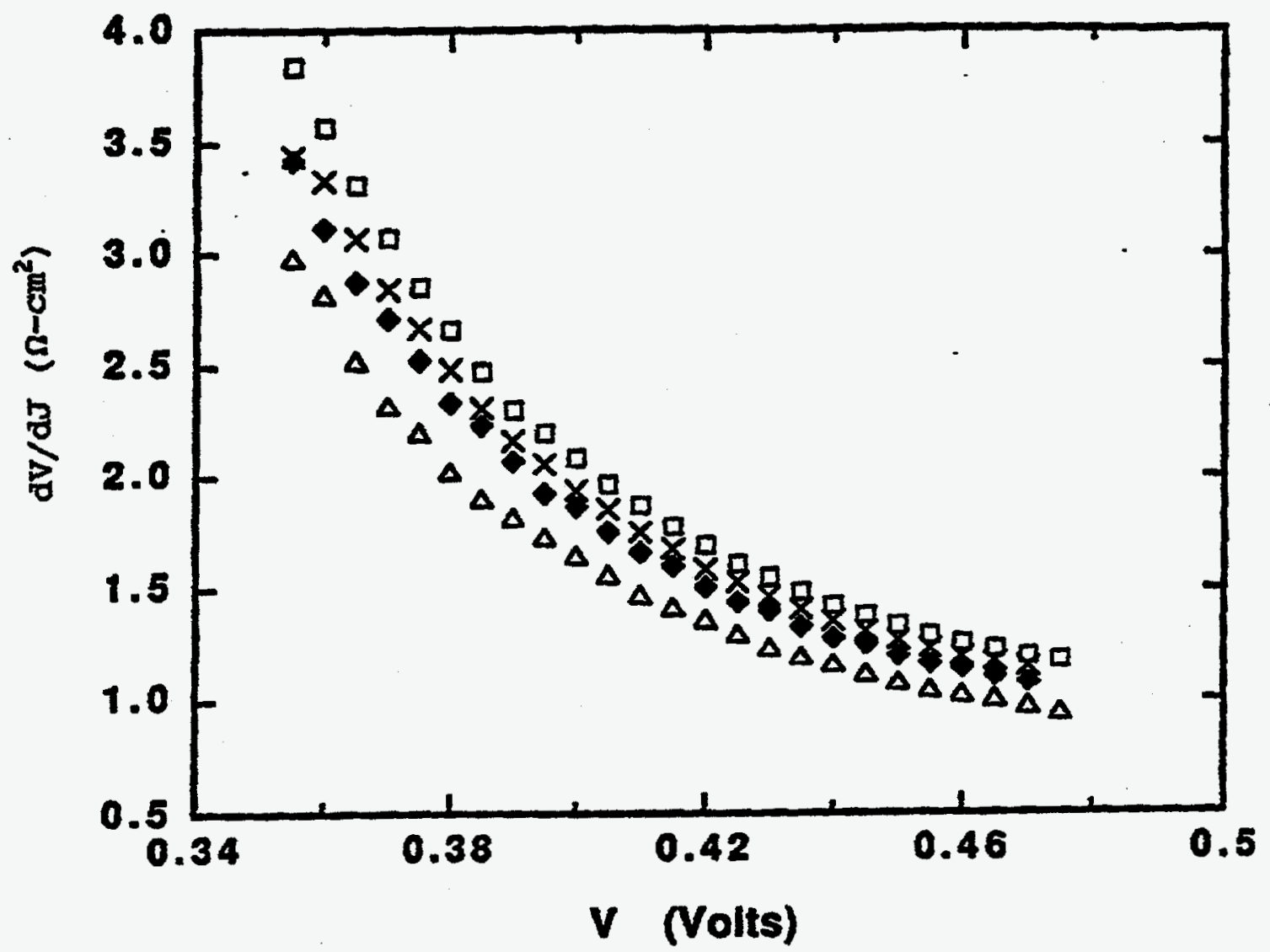

Figure 12. Slope dV/dJ of cell 2 at forward bias giving upper bound to series resistance. 


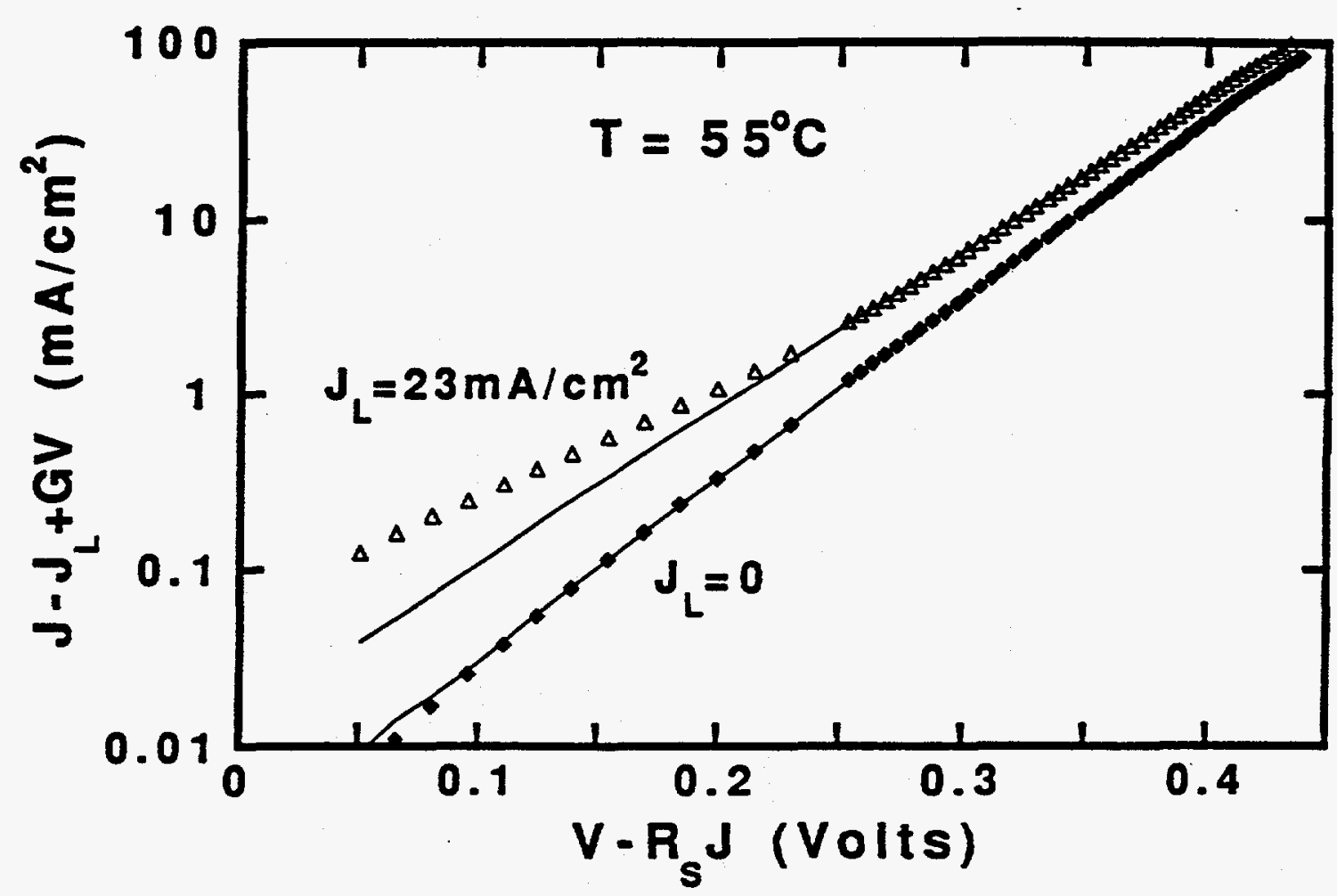

Figure 13. In $\left(J^{\prime}\right)$ vs $\nabla-R_{s} J$ used to determine A for cell 2 , showing a single $A$ factor at a given intensity and in the dark. 
Table 3. Diode Parameters at $55^{\circ} \mathrm{C}$ and Different Intensities

\begin{tabular}{|c|c|c|c|c|c|}
\hline Cell \# & $\mathrm{J}_{\left(\mathrm{mA} / \mathrm{cm}^{2}\right)}$ & $\underset{\left(\mathrm{mS} / \mathrm{cm}^{2}\right)}{\mathrm{G}}$ & $\underset{\left(\Omega-\mathrm{cm}^{2}\right)}{R_{s}}$ & A & $\underset{\left(\mathrm{mA} / \mathrm{cm}^{2}\right)}{\mathrm{J}_{0}}$ \\
\hline \multirow[t]{4}{*}{1} & 0 & 0.05 & 0.6 & 1.50 & $4 \times 10^{-3}$ \\
\hline & 1.7 & 0.1 & 0.6 & 1.49 & $4 \times 10^{-3}$ \\
\hline & 5.9 & 0.2 & 0.6 & 1.53 & $5 \times 10^{-3}$ \\
\hline & 23 & 0.5. & 0.5 & 1.73 & $1 \times 10^{-2}$ \\
\hline \multirow[t]{4}{*}{2} & 0 & 0.08 & 0.6 & 1.60 & $3 \times 10^{-3}$ \\
\hline & 1.7 & 0.1 & 0.6 & 1.61 & $5 \times 10^{-3}$ \\
\hline & 5.9 & 0.2 & 0.6 & 1.64 & $6 \times 10^{-3}$ \\
\hline & 23 & 0.6 & 0.5 & 1.76 & $1 \times 10^{-2}$ \\
\hline
\end{tabular}

would indicate an interface recombination current. A fit to the data with an $A=1$ component would require a series resistance much larger than the bound imposed by $d v / d J$ at forward bias.

The temperature dependence of the A factor determined by the diode analysis is shown in Fig. 14 for cell 1 (which had a larger temperature range unaffected by the back diode). While there is some scatter in the values of $A$ there is no evidence of any temperature dependence other than that predicted by eqn. $2.3(1)$ and therefore no evidence of a tunnelling recombination current.

The temperature dependence of $\mathrm{V}_{\text {oc }}$ is shown in Fig. 15 over the entire range since the back diode does not affect $\mathrm{v}_{\mathrm{oc}}$. Extrapolation to $T=0$ gives $\phi=0.99 \mathrm{eV}$ at the three intensities for sample 1 and $0.91 \mathrm{eV}$ for sample 2 . $\ln \left(\mathrm{J}_{0}\right)$, determined by the above procedure, is plotted against $1 / \mathrm{T}$ in $\mathrm{Fig.} \mathrm{16.} \mathrm{The} \mathrm{slopes}$ of the regression lines equal $-\phi / \mathrm{AkT}$ according to eqn. 4 and give $\phi=0.98-1.00 \mathrm{eV}$ using average values of $A=1.60$ for $J_{L}<6 \mathrm{~mA} / \mathrm{cm}^{2}$ and $A=1.75$ for $23 \mathrm{~mA} / \mathrm{cm}^{2}$. For sample 2 this gives $\phi=0.89-0.95 \mathrm{eV}$ with $A=1.51$ and 1.75 . While there is more uncertainty in determining the barrier height, $\phi$, from $J_{0}$ due to the fitting procedures and the smaller temperature range, the results give good agreement with the intercept from the $\mathrm{V}_{\text {oc }}-\mathrm{T}$ data. Again, $\phi$ is constant while $A$ increases confirming that the activation energy of $J_{0}$ is $\mathrm{E}_{\mathrm{a}}=\phi / \mathrm{A}$. 


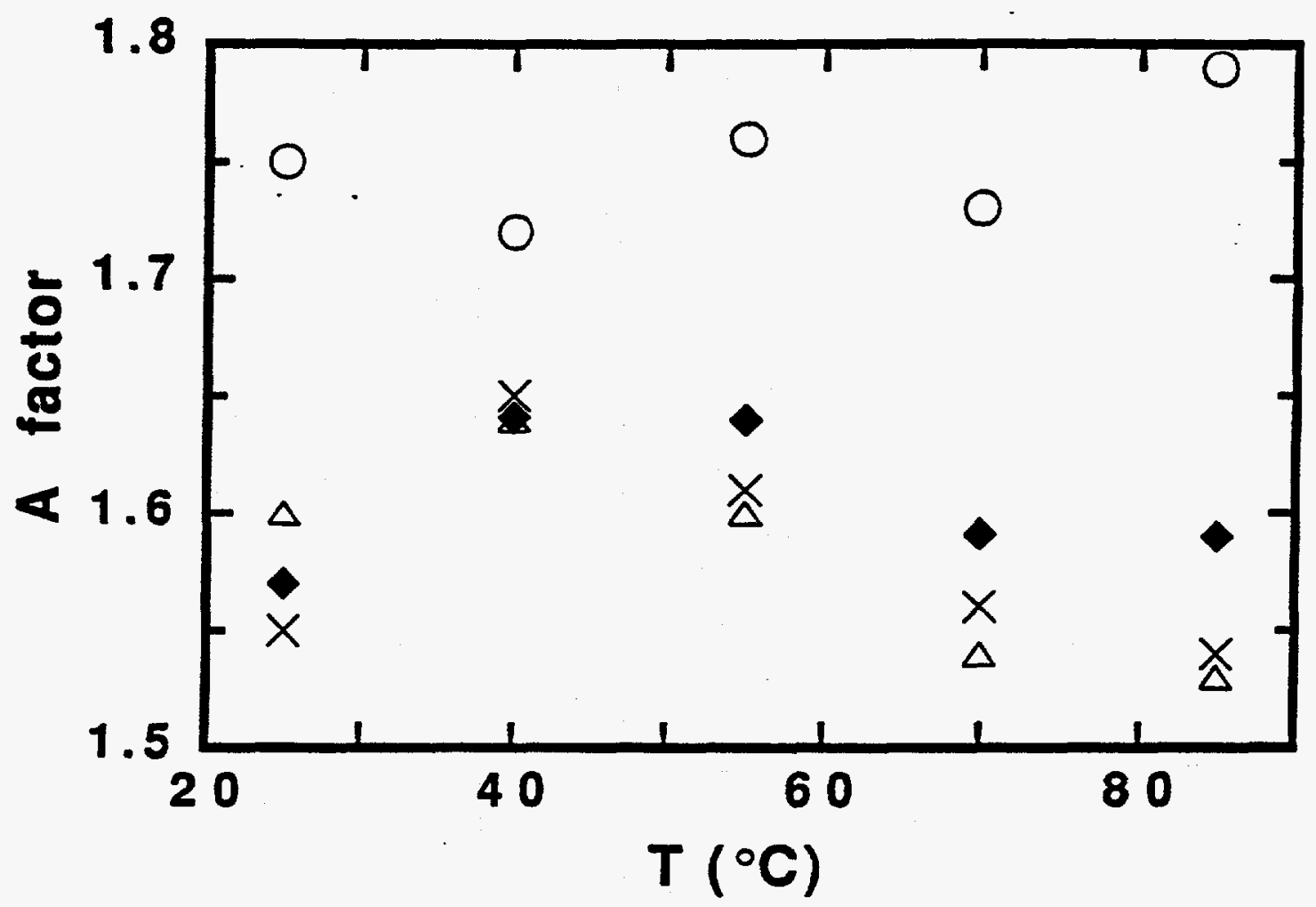

Figure 14. A factor of $J_{1}=0,1.7,5.9$ and $23 \mathrm{~mA} / \mathrm{cm}^{2}$ (from bottom $T=25^{\circ} \mathrm{C}$ ). Uncertainty in $A$ is \pm 0.05 . 


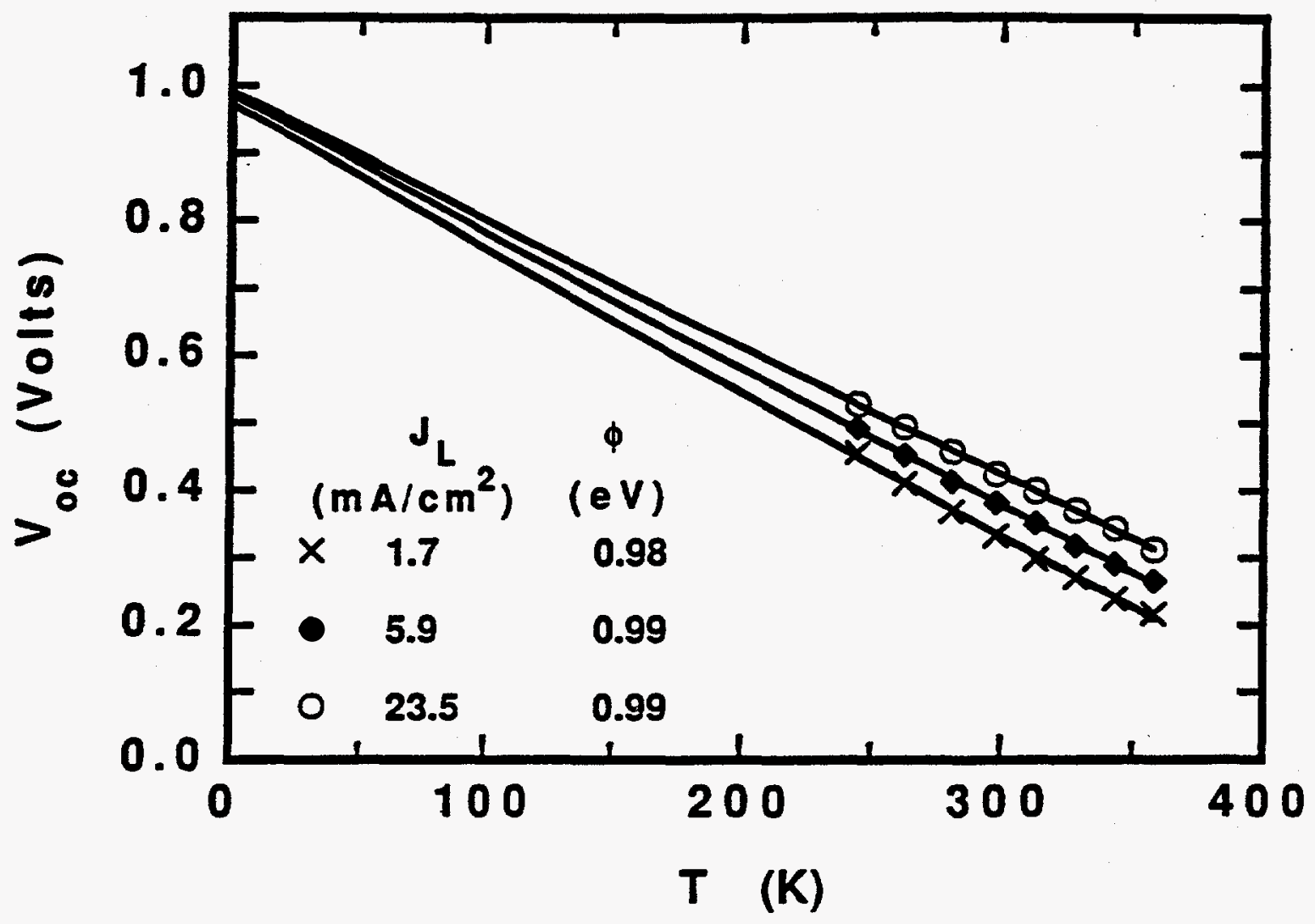

Figure 15. $\nabla_{o c}$ vs. $T$ for cell 1 showing $\phi=0.99 \mathrm{eV}$ at three intênsities. 


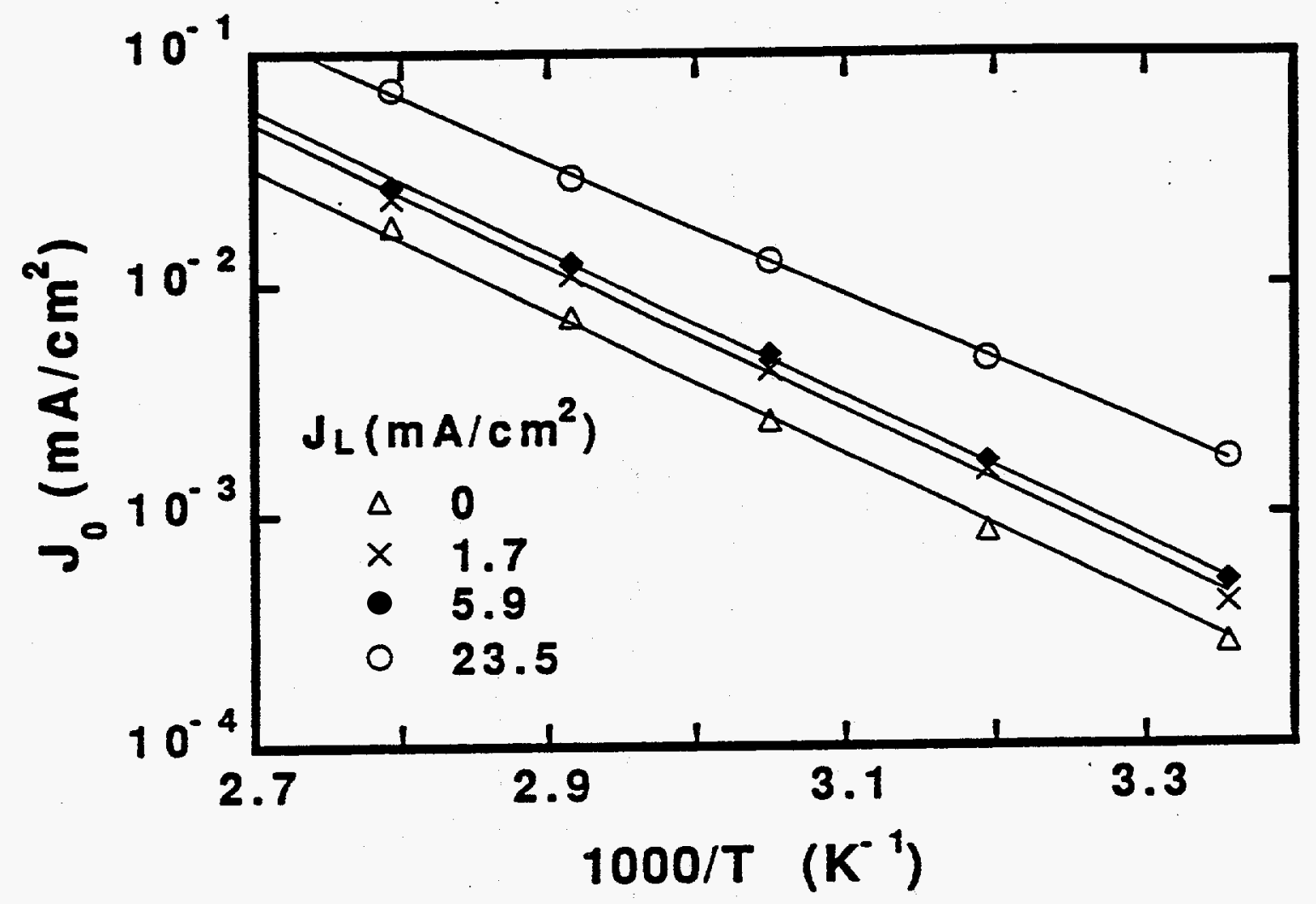

Figure 16. $J_{0}$ vs $1 / T$ for cell 1 . Slope gives $\phi=0.99 \pm 0.02 \mathrm{eV}$ at all intensities. 
The results of the $\mathrm{J}-\mathrm{V}$ analysis for the two cells studied are compared in Table 4. The cells had similar behavior in terms of the intensity dependence and each had $A=1.75$ at $J_{1}=23 \mathrm{~mA} / \mathrm{cm}^{2}$. The difference, $24 \mathrm{mV}$, in $\mathrm{V}_{o c}$ under standard measuring conditions is primarily due to the difference in $\phi$. This suggests that different states may be controlling the recombination of the CuInSe $_{2}$ layers. The change in $\phi$ may also be associated with the resistivity as previous work has shown that hydrogen heat treatments lower the barrier height of $\mathrm{CuInSe}_{2} / \mathrm{Cds}$ cells, as determined from $\mathrm{V}_{o c}-\mathrm{T}$ measurements, and increase the resistivity of CuInSe $_{2}$ films (2I).

Table 4 Comparison of Cells showing that the Difference in $V_{o c}$ Is Due to Different Barrier Height

$\begin{array}{lll} & \text { Cel1 \#1 } & \text { cel]\#2 } \\ V_{o c}(\mathrm{~V}) & 0.440 \mathrm{~V} & 0.417 \mathrm{~V} \\ \phi(\mathrm{eV}) & 0.99 \mathrm{eV} & 0.91 \mathrm{eV} \\ \mathrm{A}[\text { dark }] & 1.6 & 1.5 \\ \mathrm{~A}\left[23 \mathrm{~mA} / \mathrm{cm}^{2}\right] & 1.75 & 1.75 \\ \mathrm{~J}_{\text {oo }}[\text { dark }] \quad\left(\mathrm{mA} / \mathrm{cm}^{2}\right) & 1 \times 10^{7} & 7 \times 10^{6} \\ \mathrm{~J}_{\text {oo }}\left[23 \mathrm{~mA} / \mathrm{cm}^{2}\right]\left(\mathrm{mA} / \mathrm{cm}^{2}\right) & 6 \times 10^{6} & 2 \times 10^{6}\end{array}$

The main conclusions of this analysis of the $\mathrm{J}-\mathrm{V}$ characteristics of CuInSe $/(\mathrm{Cdzn}) \mathrm{S}$ cell are that $\mathrm{V}_{\text {oc }}$ is controlled by a single current mechanism, SRH recombination in the cuInSe, with no evidence for interface recombination, tunnelling or other mechanisms. Superposition of the dark and light $\mathrm{J}-\mathrm{V}$ characteristics does not hold with light intensity dependent $G$, $A$, and $J_{0}$, indicating that photo-activated states play a role in the recombination.

\subsection{3 $\underline{V}_{\text {oc Limitations and solutions }}$}

Analysis of the $J-V$ characteristics as a function of temperature

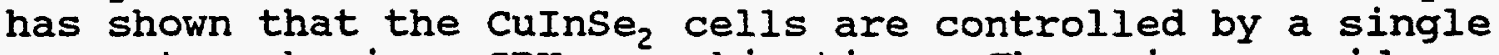
current mechanism, SRH recombination. There is no evidence of a transition to a lower A factor at forward bias as had been predicted by a standard interface recombination model. And the diode behavior at a given intensity is described by the standard temperature dependence of eqn. 3 with no evidence of tunnelling or other mechanisms with different temperature dependence. 
The light intensity dependence of $A, G$, and $J_{0}$ indicates further that photoactivated states in the CuInSe ${ }_{2}$ affect the diode current. Reducing the $A$ factor with a constant $\phi$ and $J_{\infty}$ would give an increase in $\mathrm{V}_{\text {oc }}$. Therefore, it would be beneficial to determine what states control the light dependent effects by comparing models of the recombination in the cuInse chith $_{2}$ measurements of defect state energies and densities.

Other current paths are expected to affect $J_{0}$ and $V_{o c}$ if the $S R H$ recombination through states in the $\mathrm{CuInSe}_{2}$ is reduced. The interface recombination should finally limit $v_{o c}$. However, a more comprehensive model of the recombination is needed to account for grain boundary and photoactivated states in the CuInSe, $_{2}$ and at the interface.

\subsubsection{Future Work}

Improvements in $\mathrm{V}_{\text {oc }}$ will result from decreasing the SRH recombination by either reducing the density of recombination centers $N_{R}$, lowering the $A$ factor, or increasing the bandgap of the $\mathrm{CuInSe}_{2}$ in the region near the interface. Lowering $J_{\infty}$ by reducing $\mathrm{N}_{R}$ will require determining which defect states control the recombination and how they can be controlled by modifying the cuInse, deposition. This will be difficult since the films have a wide variety of both bulk and grain boundary defects. Further work will be needed to attempt to identify the energies of states controlling the diode effects and to which physical defects they correspond.

Efforts to introduce a thin $\mathrm{Cu}$ (InGa) $\mathrm{Se}_{2}$ layer to increase the bandgap near the interface and increase $v_{o c}$ have not resulted in significant improvements (2). This approach should work if the electrical properties of the bandgap modified layer can be controlled to keep the increase in the valence band and prevent a barrier to photogenerated carrier collection in the conduction band.

Incorporation of a thin Ga layer at the back of the $\mathrm{Cu}$ layer in $\mathrm{Cu} /$ In layers used for selenization has been reported to increase $v_{\text {oc }}(27)$. We have previously investigated the effect of a thin $\mathrm{Ga}$ layer at back of evaporated CuInse, (2) with no improvement due to incomplete or non-uniform reaction with the $\mathrm{Ga}$. We will

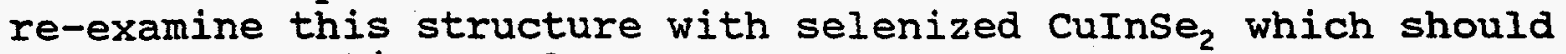
form more continuous layers.

\subsection{CaTE DEVICE OPERATION}

After a cdTe/CdS solar cell has been fabricated and contacted, (described in section 3.2) further treatments are required to dope the cate p-type and improve cell performance. The final 
aspect of fabricating high efficiency cdTe/CdS cells is type conversion of the cdTe to p-type. In general a p-type dopant, typically $\mathrm{Cu}$, is diffused from the contact to the caTe. The contact may be $\mathrm{Cu} / \mathrm{Au}$ (23), graphite/Cu $(24)$ or ZnTe:Cu $(25,26)$. The evolution of device performance is summarized below. A more complete discussion with supporting optical, Auger and SIMS data appears in reference 23. CdTe/CdS samples made at IEC were prepared with a semi-transparent $\mathrm{Cu} / \mathrm{Au}$ contact using the procedure described above. The $\mathrm{Cu} / \mathrm{Au}$ contact was deposited after the $400^{\circ} \mathrm{C}, \mathrm{CdCl}_{2}$ heat treatment in air. Figures 17 and 18 show the initial $I-V$ curve and quantum efficiency measurements for illumination through both the CaS and $\mathrm{Cu} / \mathrm{Au}$ contact. Initially, $V_{o c}$ is less than $400 \mathrm{mV} ; J_{s c}$ is less than $10 \mathrm{~mA} / \mathrm{cm}^{2}$, FF less than $40 \%$, and the $J-V$ curve has pronounced light-to-dark crossover. The quantum efficiency measurements show nearly uniform collection, independent of the illumination direction, indicating that there is a photovoltaic junction both at the contact and cas.

Figures 19 and 20 show the $I-V$ curve and quantum efficiency measurements for illumination through the CdS and $\mathrm{Cu} / \mathrm{Au}$ after air heat treatment at $150^{\circ} \mathrm{C}$ for 30 minutes. $J_{s c}$ increased to 19 $\mathrm{mA} / \mathrm{cm}^{2}$, and $\mathrm{V}_{o c}$ increased to $670 \mathrm{mV}$ for illumination through the Cds. The curvature in forward bias is due to the remaining non-ohmic behavior of the $\mathrm{Cu} / \mathrm{Au}$ contact. The dark I-V characteristic was unchanged by the heat treatment. The quantum efficiency for illumination through the cas increased uniformly while that for illumination through the $\mathrm{Cu} / \mathrm{Au}$ contact decreased overall, with the maximum response near the cdTe absorption edge. The quantum efficiency results suggest a shift from a $p-i-n$ type junction to a $\mathrm{p}-\mathrm{n}$ heterojunction between $\operatorname{cdTe}_{1-\mathrm{x}} \mathrm{S}_{\mathrm{x}}$ and $\mathrm{CdS}_{1-\mathrm{y}} \mathrm{Te}_{\mathrm{y}}$. Evolution from $p-i-n$ to $p-n$ behavior is consistent with the caTe becoming more p-type throughout its bulk, probably resulting from $\mathrm{Cu}$ diffusion into the cdTe from the contact during the $150^{\circ} \mathrm{C}$ heat treatment.

Cell performance improves significantly following immersion in $\mathrm{Br}_{2} \mathrm{CH}_{3} \mathrm{OH}$ for 5 seconds at room temperature. The bromine reacts with $C d$ in the near-surface region, producing excess $T e$ which may react with $\mathrm{Cu}$, to form $\mathrm{Cu}_{2} \mathrm{Te}$, and with $\mathrm{Au}$, forming an ohmic contact with p-type caTe (27). Devices up to $11 \%$ efficiency have been achieved using this optimization. $v_{o c}$ increases by $50 \mathrm{mV}$ to $100 \mathrm{mV}$ with no change in $J_{s c}$ or spectral response. Because of the speed and temperature of the reaction, the increase in $V_{\text {oc }}$ is attributed to a chemical interaction along the cdTe grain boundaries. Curvature in the forward bias portion of the I-V curves was also eliminated by the treatment. This indicates a decrease in the effective series resistance which results in an increase in FF. Similar device results have been obtained using an electrodeposited $\mathrm{ZnTe}: \mathrm{Cu}$ contact instead of the $\mathrm{Cu} / \mathrm{Au}$, although the chemical treatment was not required to obtain high $v_{\text {oc }}(26)$. 


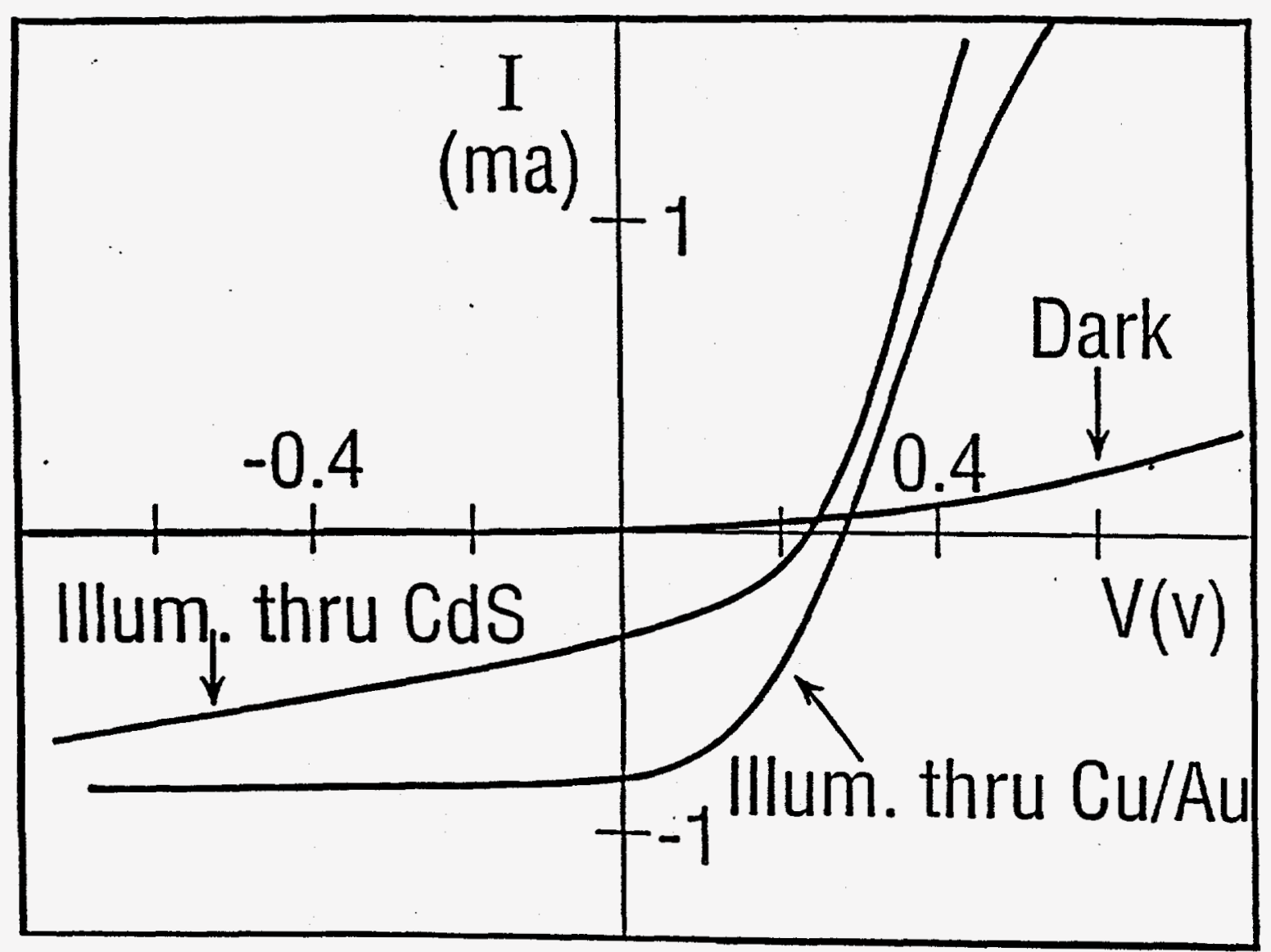

Figure 17. Current-voltage characteristics of a care/cas device with a semitransparent $\mathrm{Cu} / \mathrm{Au}$ contact before air heat treatment. 


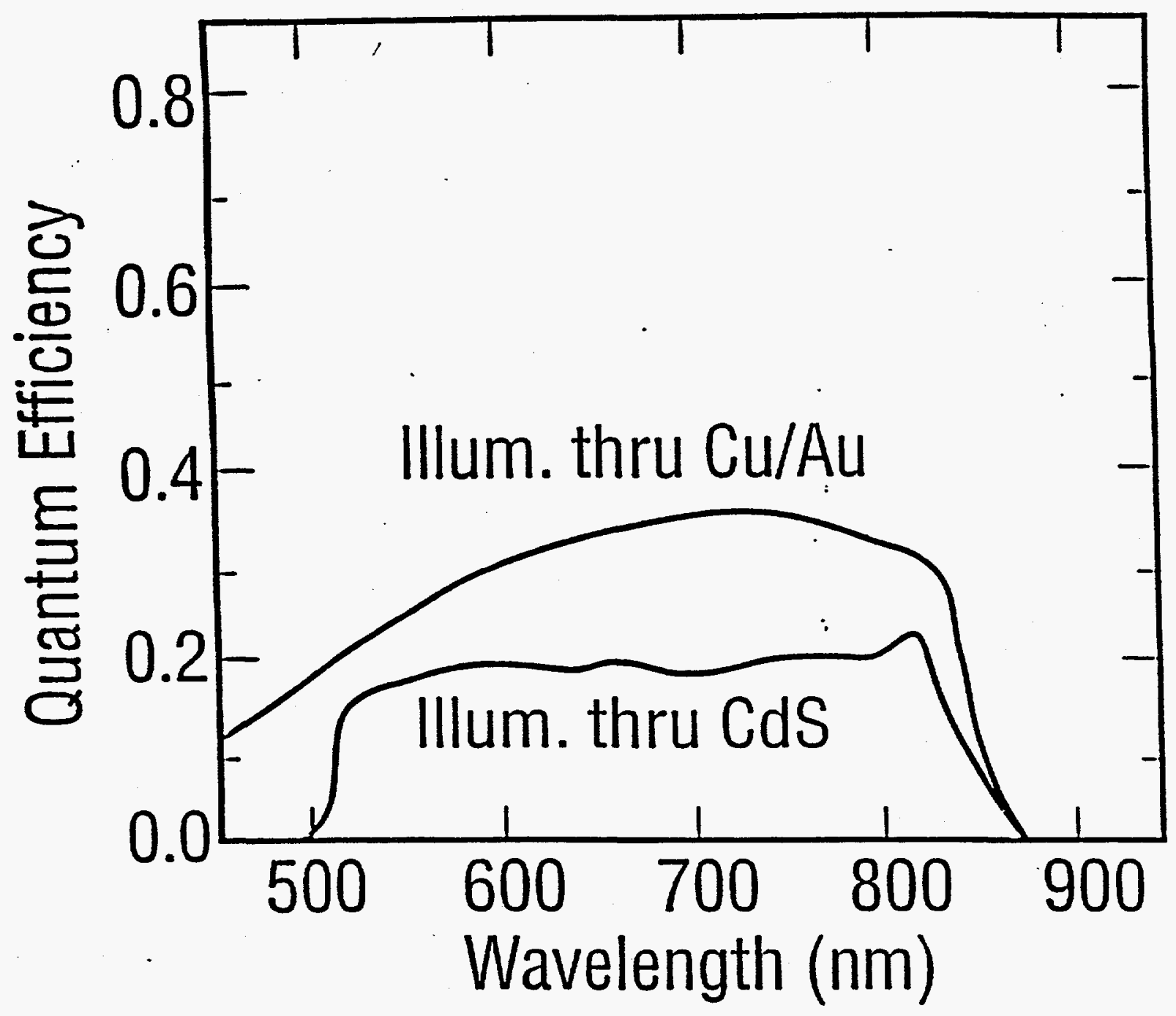

Figure 18. Q.E. measurements of a CdTe/Cds device with a semitransparent $\mathrm{Cu} / \mathrm{Au}$ contact before air heat treatment. 


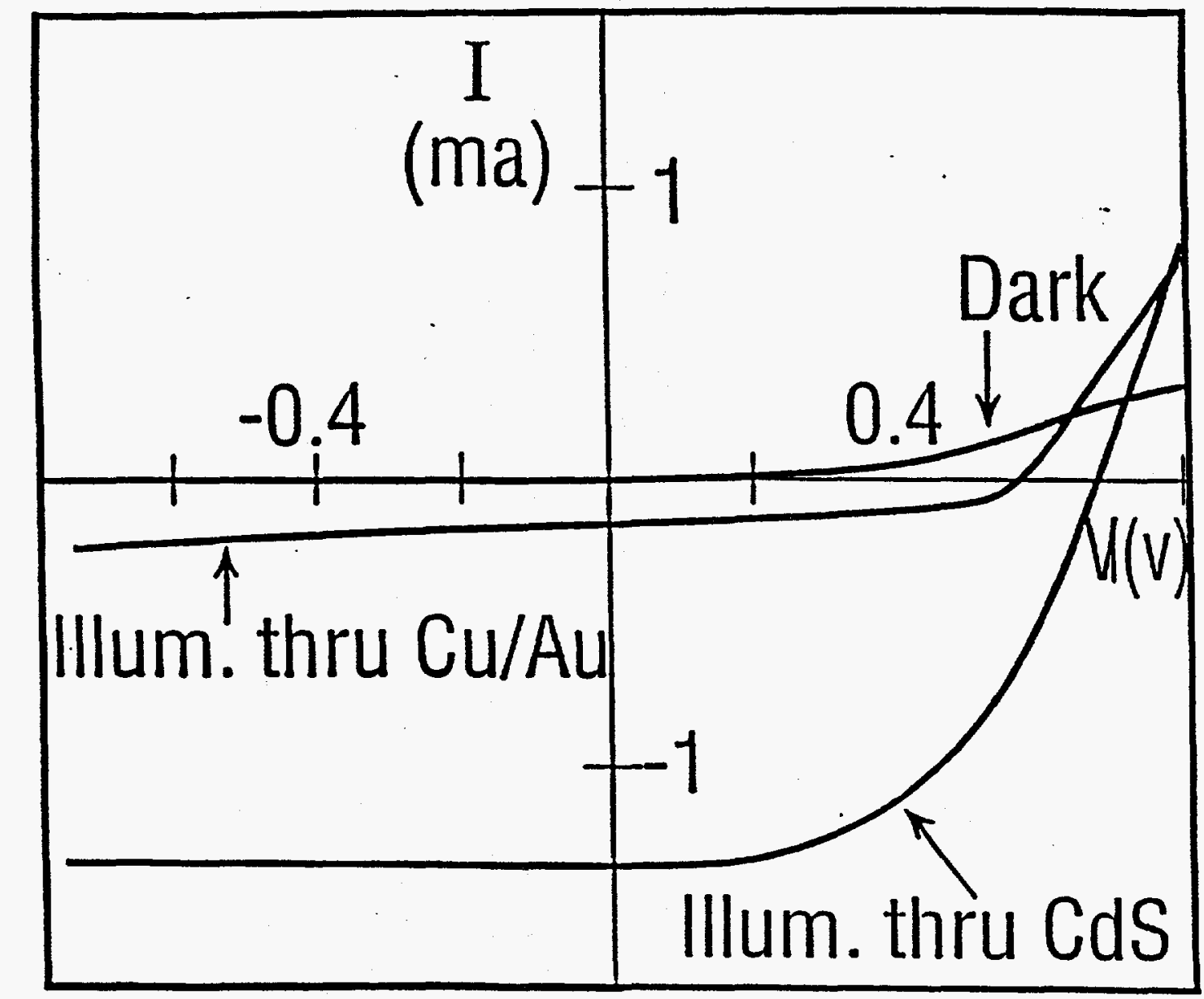

Figure 19. Current-voltage characteristics of a cdTe/cds device with a semitransparent $\mathrm{Cu} / \mathrm{Au}$ contact after air heat treatment. 


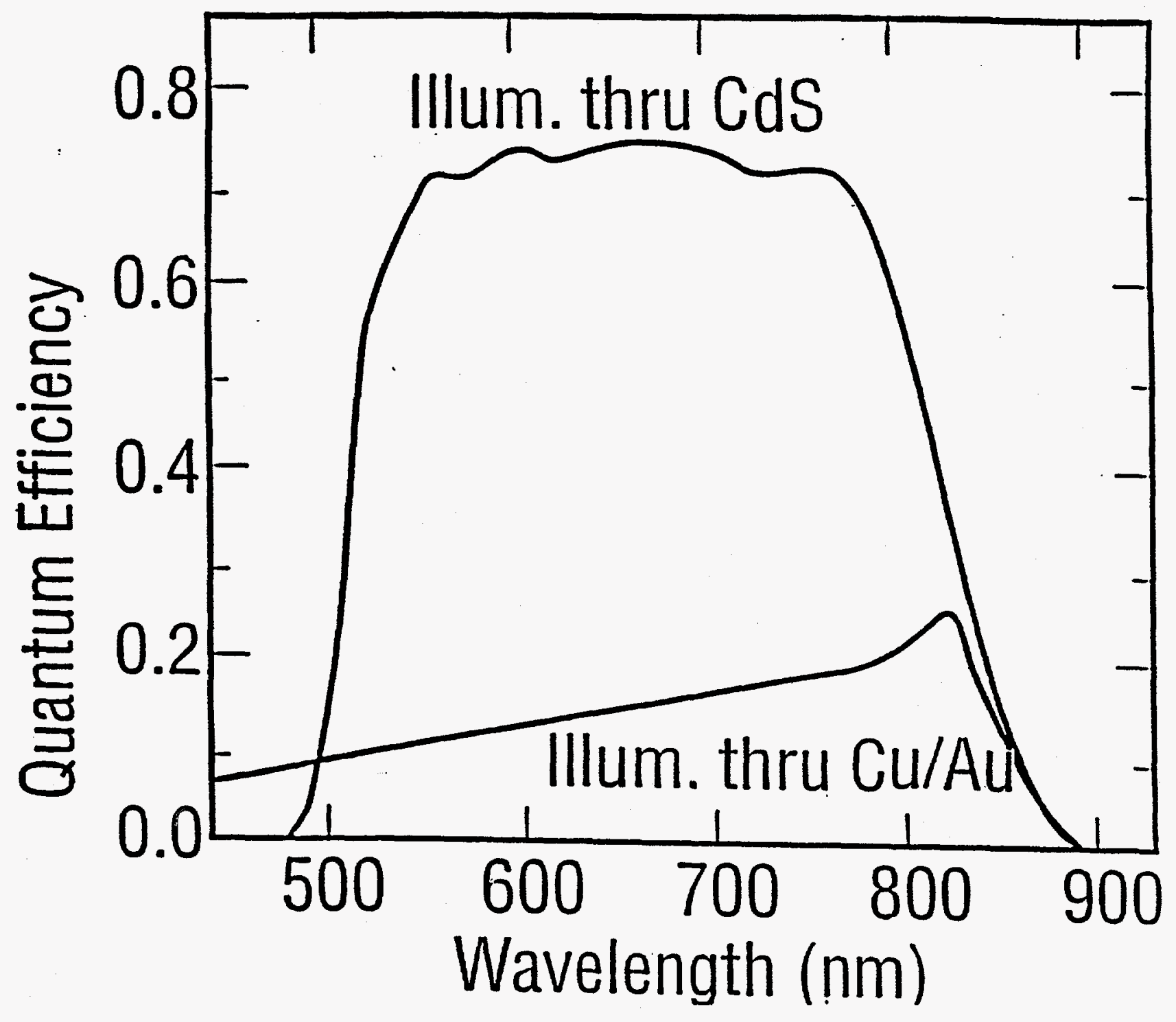

Figure 20. Q.E. measurements of a cdTe/Cds device with a semitransparent contact after air heat treatment. 
Additional current-voltage and spectral response measurements have been made on high efficiency CdTe/Cds thin film solar cells prepared by vacuum evaporation $(n=9.6 \%)$. Analysis of the measurements indicate that these solar cells operate as $p-n$ heterojunctions and the current transport in the junction region is dominated by Shockley-Read-Hall recombination in the CdTe. The analysis also indicates that the light generated current varies with the applied voltage.

Frontwall spectral response measurements made as a function of voltage bias and normalized with respect to the spectral response made at $J_{s c}[Q E(-V, \lambda) / Q E(O V, \lambda)]$ are shown in Figure 21. The preferentially increasing spectral response at larger wavelengths suggests that current collection may be a function of the width of the space charge region of the caTe. In any case, this variation will cause a change in the collected current $\left(J_{L}\right)$ as a function of voltage bias is indicated $\left(J_{L}(V)\right)$. The integrated effect of this for reverse bias is shown in Figure 20.

Measurements of $J_{L}(V)$ in forward bias could not be made because of device series resistance effects and particularly photoconductive effects in the Cas and CaTe $(28,29)$.

Current-voltage measurements in the dark and under AMI.5

illumination were made at five temperatures from $301^{\circ} \mathrm{K}$ to $343^{\circ} \mathrm{K}$ (Figure 22). Lower temperature current-voltage traces were not used in the analysis because of hysteresis in the trace going from forward to reverse scans. Temperatures above about $70^{\circ} \mathrm{C}$ were avoided due to irreversible heat treatment effects.

Measurements of $\mathrm{V}_{o c}$ and $\mathrm{J}_{\mathrm{sc}}$ were recorded (Table 5) as well as the slope or derivative of the current-voltage curve (Figure 23).

The current-voltage measurements in the dark were fitted to the equation:

$$
J-G V=J_{0} \exp [q(V-R J) / A k T]
$$

with:

$$
J_{0}=J_{00} \exp \quad(-q \phi / A k T
$$

If: $J^{\prime}=J-G V$

and: $\mathrm{V}^{\prime}=\mathrm{V}-\mathrm{RJ}$

then equation 6 reduces

to: $J^{\prime}=J_{0} \exp \left(q V^{\prime} / A k T\right)$ 


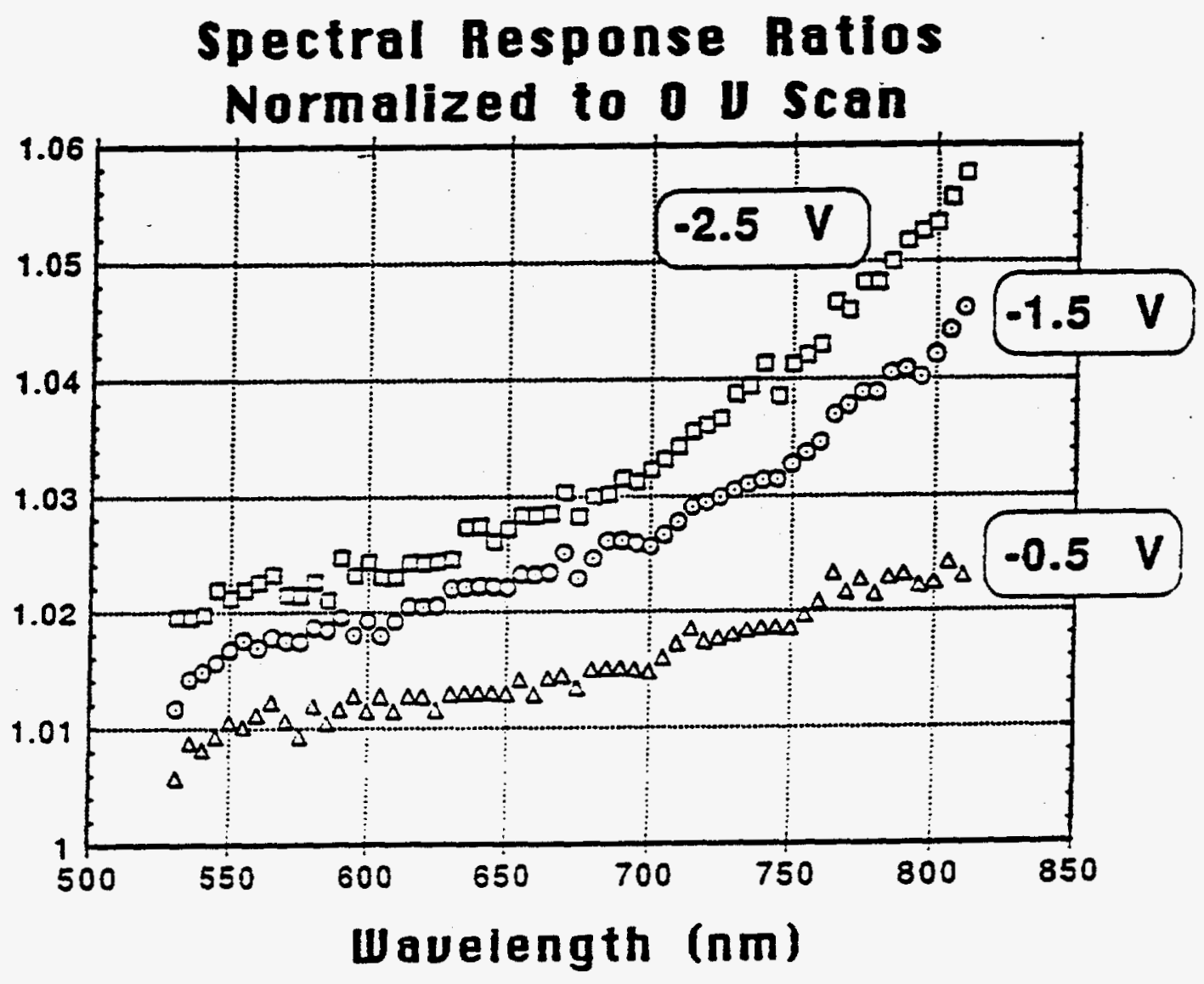

Figure 21. Spectral response in reverse bias normalized to zero bias. 
Measured $J_{L}(U)$

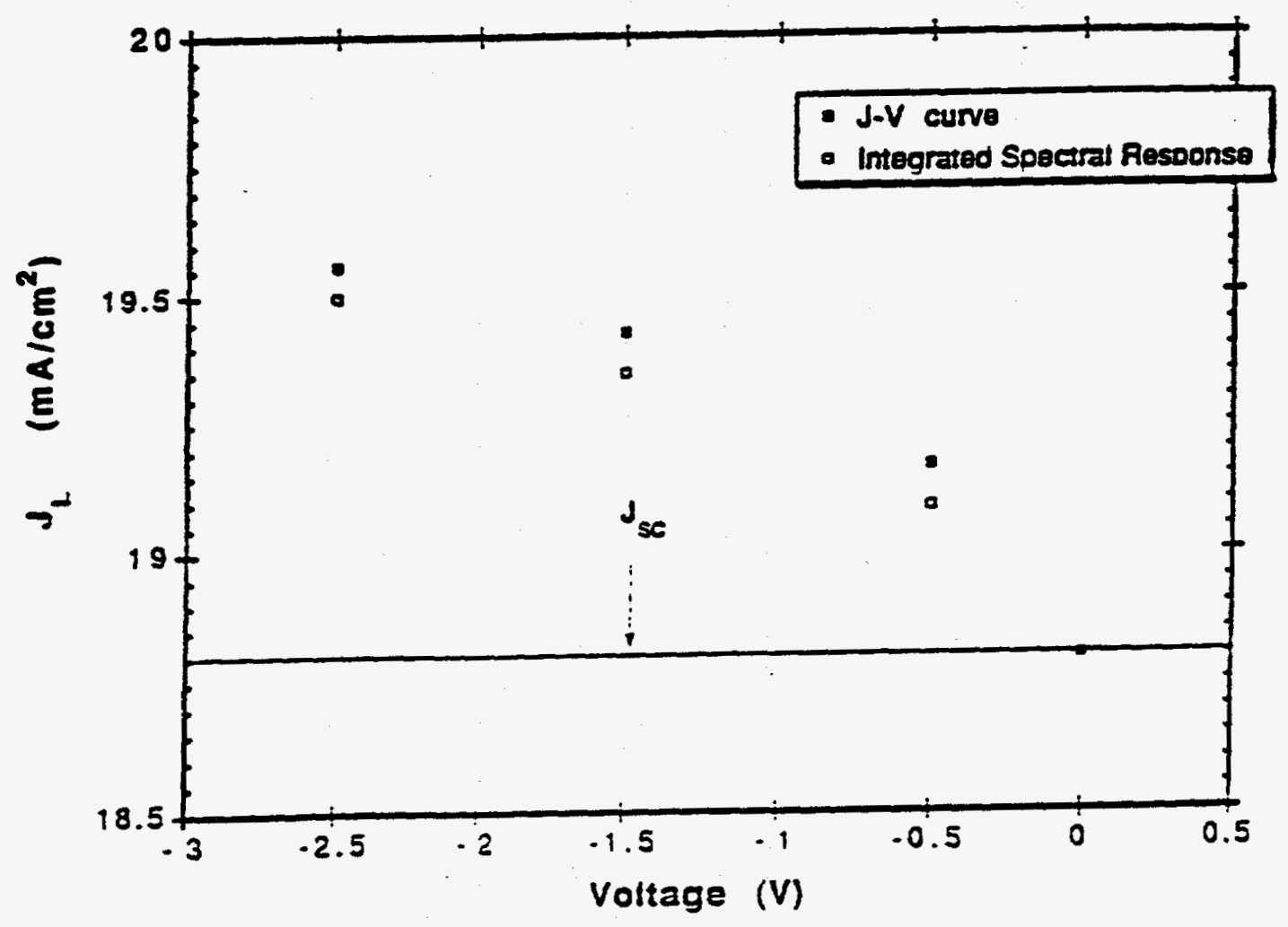

Figure 22. Comparison of measured $J$ to calculated from integrated spectral response. 


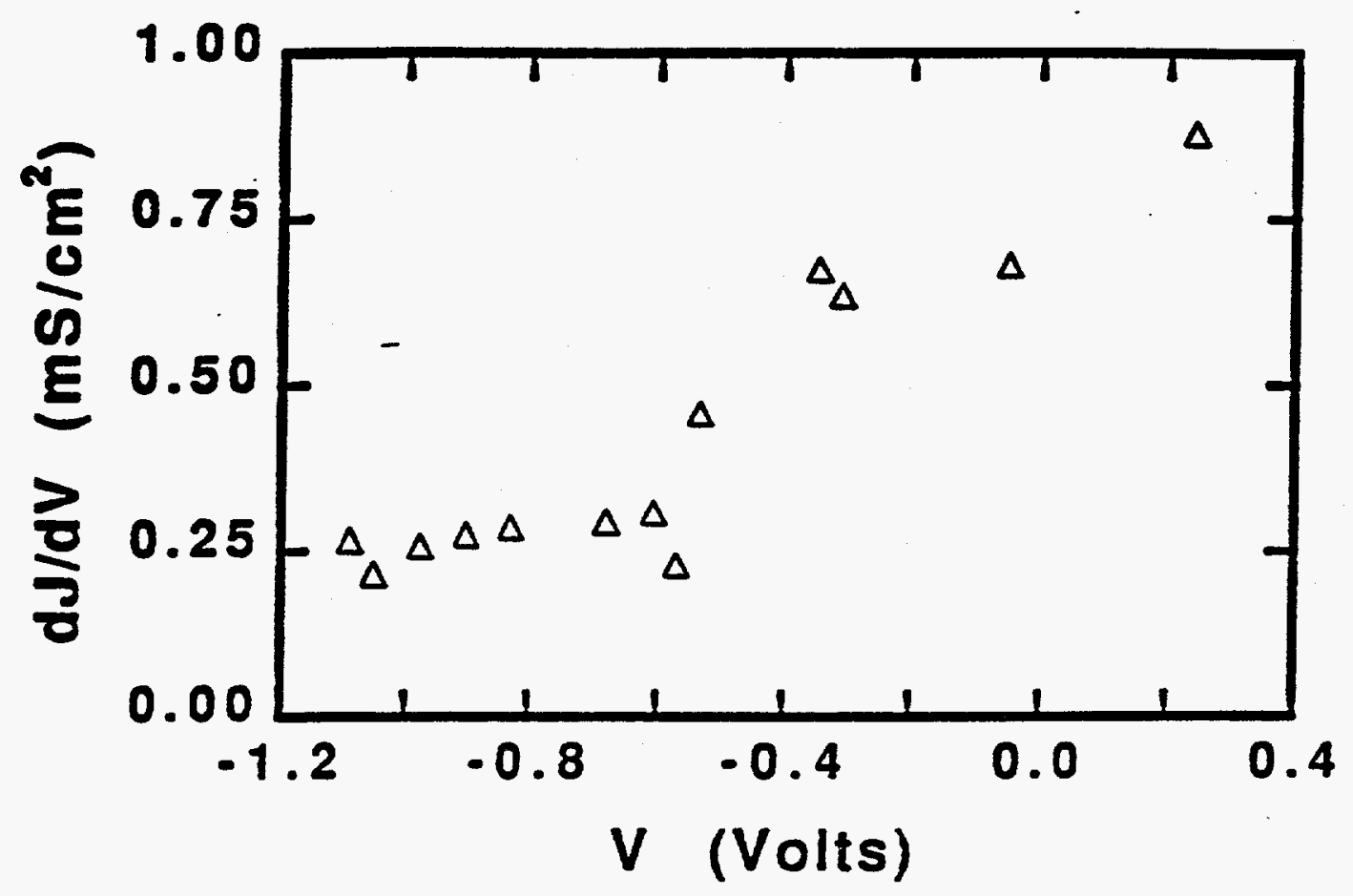

Figure 23. Slope of $J-V$ curve (dJ/dV) (Dark $T=301 \mathrm{~K}$ ) 
The maximum value of the shunt conductance (G) can be determined from the minimum value of $d J / d V$ as shown in Figure 23. In the case of the dark current voltage measurements, this was a negligible value of $0.2 \mathrm{~ms} / \mathrm{cm}^{2}$.

The values of the series resistance. (R), the diode quality factor (A), and the reverse saturation current $J_{0}$ are chosen to best linearize the InJ' vs. V curve as shown in Figure 24. The best values gave a temperature dependent $R$ as shown in Table 5 with a diode quality factor of about 1.7. A plot of $J_{0}$ vs. 1/T yielded $\phi$ of about $1.3 \mathrm{eV}$ and $a J_{00}$ on the order of $10^{7} \mathrm{~mA} / \mathrm{cm}^{2}$.

\section{Table 5}

Diode Parameters that are a Function of Temperature

$\begin{array}{llclc}\begin{array}{c}\text { Temp } \\ \left({ }^{\circ} \mathrm{K}\right)\end{array} & \begin{array}{l}\mathrm{V}_{\mathrm{oc}} \\ (\mathrm{V})\end{array} & \begin{array}{c}\mathrm{J}_{\mathrm{sc}} \\ \left(\mathrm{mA} / \mathrm{cm}^{2}\right)\end{array} & \begin{array}{l}\text { Light } \\ \left(\Omega-\mathrm{cm}^{2}\right)\end{array} & \begin{array}{c}\text { Dark } \\ \mathrm{R}\end{array} \\ 301 & 0.700 & 18.8 & 1.3 & 2.3 \\ 312 & 0.678 & 19.0 & 0.8 & 1.2 \\ 323 & 0.654 & 19.1 & 0.6 & 0.8 \\ 334 & 0.628 & 19.2 & 0.5 & 0.6 \\ 343 & 0.610 & 19.3 & 0.4 & 0.4\end{array}$

Because of the voltage dependent current collection $\left(J_{L}(V)\right.$ ) shown by the spectral response measurements, it is not as easy to analyze the illuminated current-voltage measurements as the dark ones. However, it is still possible to fit to a similar set of equations where the change in $J_{L}$ can be either neglected or measured. This time the equations can be written

$J+J_{S c}-G V=J_{0} \exp \left[q(V-R J / A k T]+\delta J_{L}(V)\right.$

with $\mathrm{J}^{\prime}=\mathrm{J}+\mathrm{J}_{\mathrm{sc}}-\mathrm{GV}$

The maximum value of the shunt conductance (G) can be determined as in the dark. In this case $G$ was again a negligible value of $0.6 \mathrm{~ms} / \mathrm{cm}^{2}$.

The values of the series resistance (R) and the diode quality factor (A) can still be determined by linearizing the InJ' vs $V$ curve in far forward bias where the effect of $\left(\delta J_{1}(V)\right)$ on the slope is negligible. This is shown in Figure 25. Again, the best values gave a temperature dependent $R$ as shown in Table 5 . The diode quality factor (A) was found to be about 1.9. 


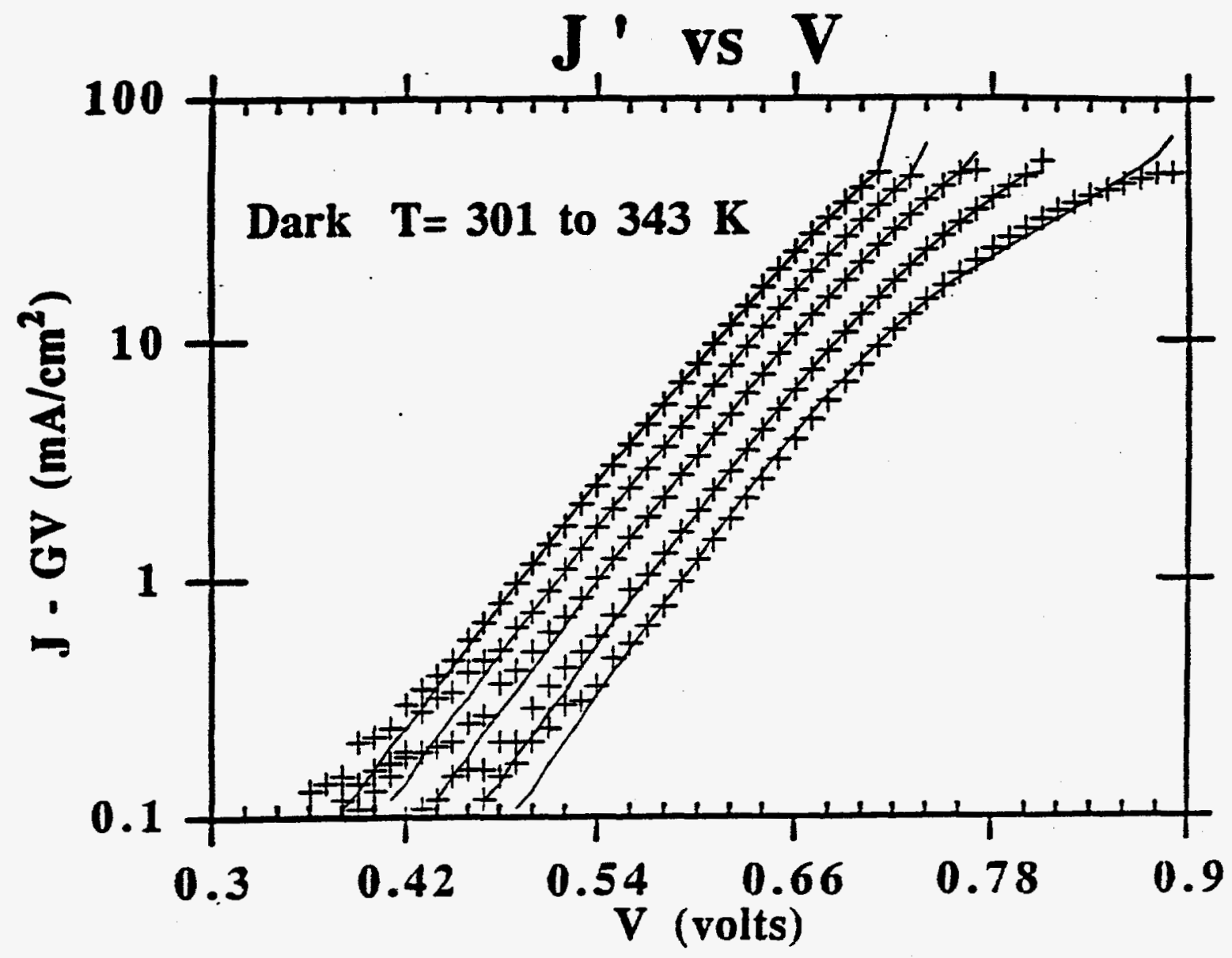

Figure 24. $J^{\prime}$ (corrected for shunt conductance) vs. V (Line is for $A=1.7$ ). 


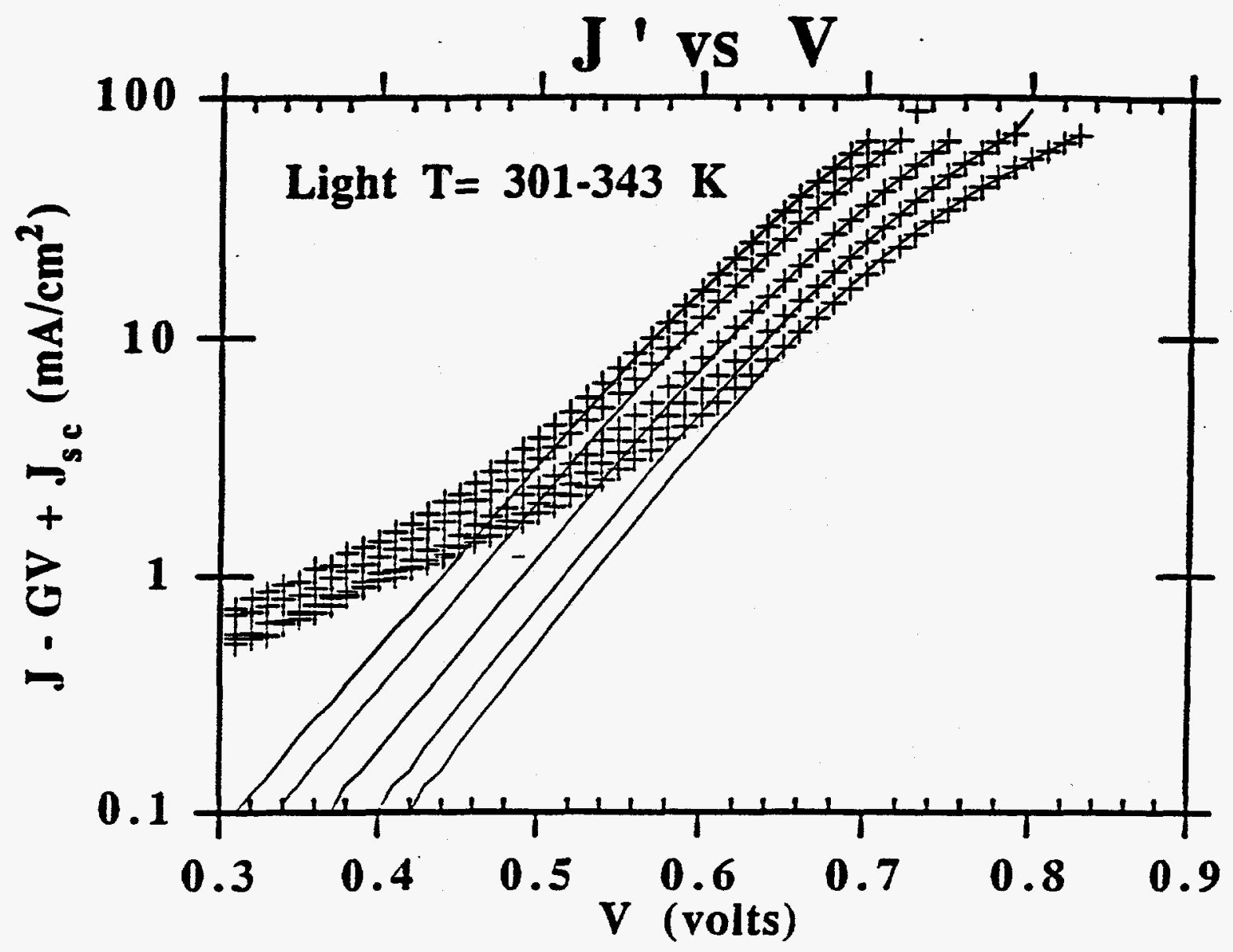

Figure 25. $J^{\prime}$ (corrected for shunt conductance and short circuit current) vs. $v$. (Line is for $A-1.9$ ). 
The reverse saturation current $\left(J_{0}\right)$ cannot be determined accurately in this case because of the unknown effect of $\delta J_{L}$ on the intercept of $\mathrm{LnJ}^{\prime}$ vs. V.

However, this can be gotten around by examining $V_{o c}$. At $V=V_{o c}$ equation 11 becomes:

$\mathrm{V}_{o c}=\phi+\mathrm{AkT} / \mathrm{q}\left[\operatorname{Ln}\left(J_{s c} / J_{\infty 0}\right)+\operatorname{Ln}\left(1-\delta J_{L} / J_{s c}\right)\right]$

Because $\delta J_{L}\left(V_{o c}\right)$ has a small variation with respect to temperature, the barrier height under illumination can be determined from $V_{o c}$ vs. $T$ as shown in Figure 26 . Knowing the diode quality. factor $(A \approx 1.9) J_{00}$ can also be determined.

In this case the barrier height $\phi$ is about $1.35 \cdot \mathrm{eV}$ and $J_{\infty}$ is also on the order of $10^{7} \mathrm{~mA} / \mathrm{cm}^{2}$. Finally, the diode part of the current-voltage characteristic can be subtracted from the measured $J-V$ data giving $\delta J_{L}(V)$ as shown in Figure 27 . The increasing $\delta J_{L}(V)$ in forward bias is qualitatively consistent with the spectral response measurements.

If the voltage dependent current collection $\left(J_{L}(V)\right.$ ) as shown by spectral response measurements is included in the diode analysis of current-voltage measurements made under illumination, then both the dark and light analysis give a barrier height $(\phi)$ near $1.3 \mathrm{eV}$ with a diode quality factor (A) of about 1.8. These are indications that the CaTe/Cds solar cell operates as a $p-n$ heterojunction and has a current transport mechanism dominated by Shockley-Read-Hall recombination in the space charge region of the cate. 


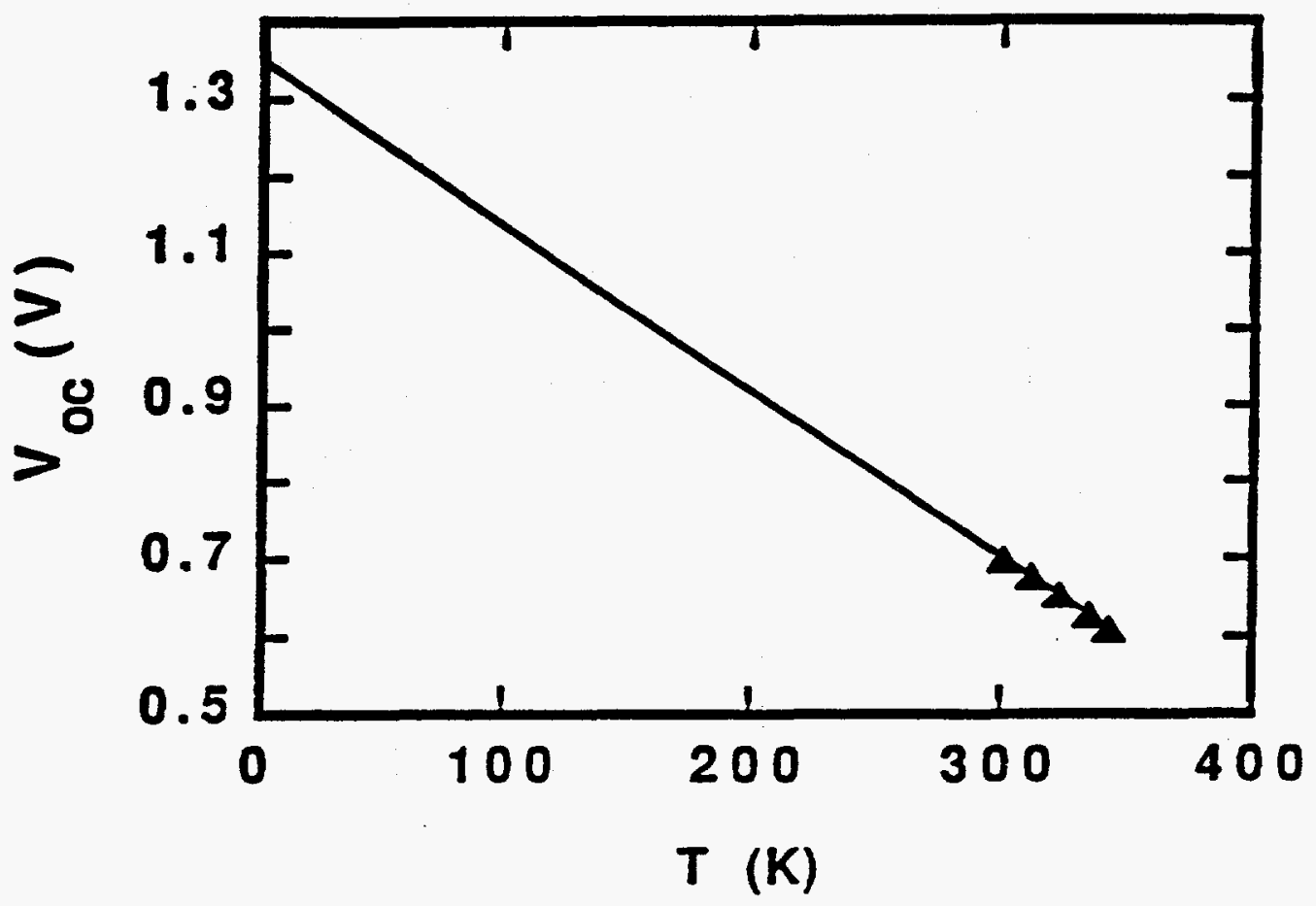

Figure 26. $\nabla_{o c}$ vs. Temperature (Intercept $=1.35 \mathrm{eV}$ ). 


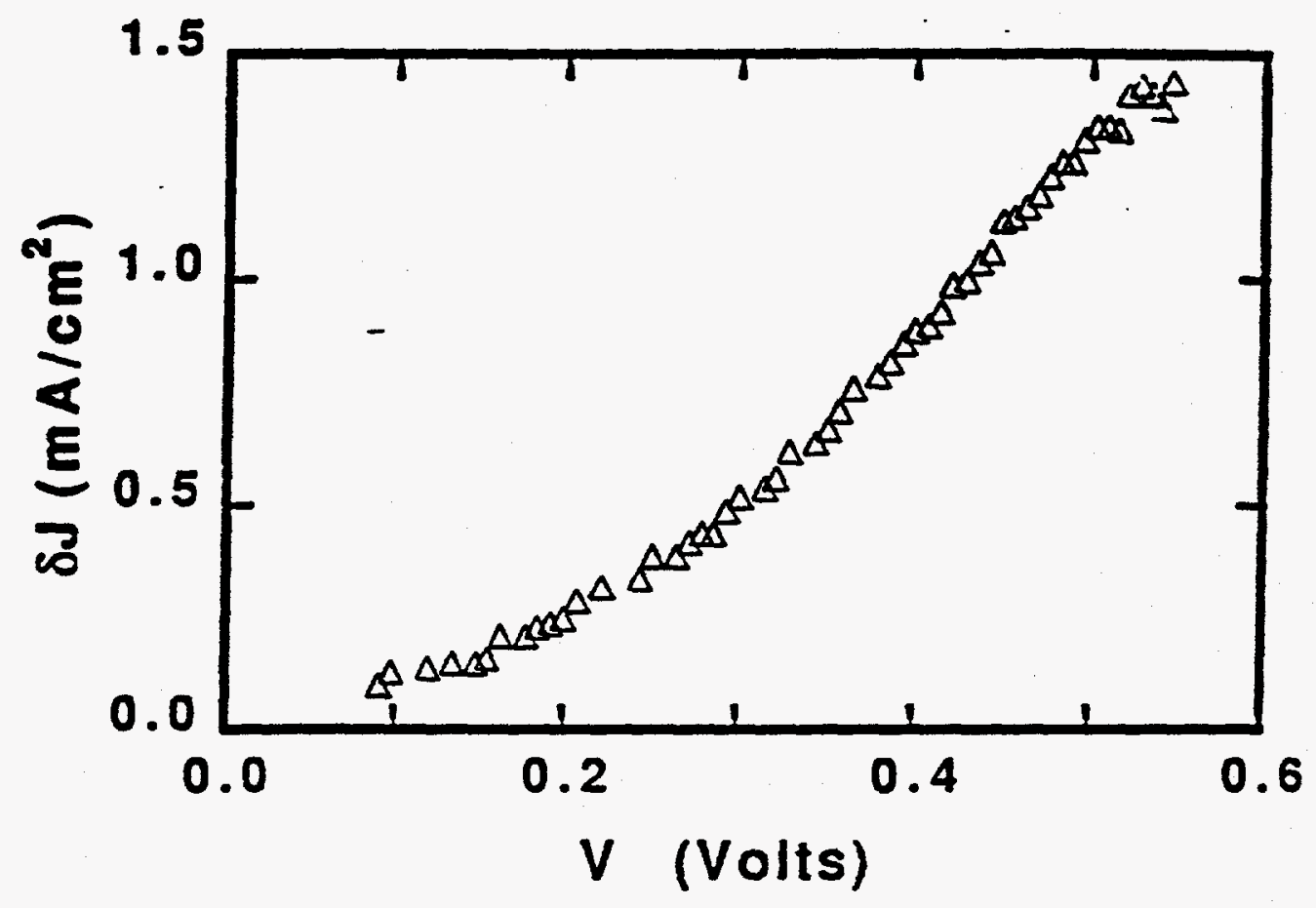

Figure 27. Change in light generated current $\left(\delta J_{L}(V)=\right.$ difference between measured and predicted $J^{\prime}$ for $A=1.9$ ). 
SECTION 3.0

MATERIALS AND DEVICE FABRICATION

\subsection{CuInSe $_{2}$ Films}

CuInSe $_{2}$ films were deposited by three source evaporation and selenization of $\mathrm{Cu} / \mathrm{In}$ layers using either elemental se or $\mathrm{H}_{2} \mathrm{Se}$. Typically, devices were fabricated in a substrate configuration by depositing CdS/ITO as a window layer as described previously (2).

Additionally, several approaches to fabricating cuInse, thin film solar cells in a superstrate configuration have-been explored. The CuInSe, films have been grown on glass/TCo/Cds substrates by both 3-source elemental evaporation and selenization, i.e. the reaction of $\mathrm{Cu}$, In and se layers in a selenium atmosphere. The structure and properties of the cdS films were varied by changing deposition conditions and post-deposition annealing in the presence of $\mathrm{Cl}$. The results of these exploratory experiments are summarized below:

1) Annealing CaS in air at 400 to $500^{\circ} \mathrm{C}$ with $\mathrm{CdCl}_{2}$ improves the optical properties and enhances the grain size of the cas as discussed in ref. (6).

2) The diffusion of $\mathrm{Cu}$ into the CdS during growth of the CuInSe is reduced when using the annealed CdS. This is inferred from devices measurements where there is a reduction in the light to dark cross-over in the I-V curves, suggesting a less resistive/photoconductive cas layer.

3) Several Cu-In-Se layer structures were evaluated using glass/TCO/CdS superstrates: $\mathrm{Cu} / \mathrm{In}, \mathrm{In} / \mathrm{Cu}, \mathrm{Se} / \mathrm{Cu} / \mathrm{In}$, and $\mathrm{Se} / \mathrm{In} / \mathrm{Cu}$. The samples were reacted with evaporated se at a substrate temperature of $400^{\circ} \mathrm{C}$. The $\mathrm{Se} / \mathrm{Cu} / \mathrm{In}$ resulted in the formation of $\mathrm{Cu}_{3} \mathrm{Se}_{2}$ at room temperature, while there was no reaction observed for the Se-In-Cu. Device results, only obtained with the $\mathrm{Se} / \mathrm{In} / \mathrm{Cu}$ structures, showed voltages of about $500 \mathrm{mV}$ but $10 \mathrm{w}$ currents, $-6 \mathrm{~mA} / \mathrm{cm}^{2}$. The se between $\mathrm{cds}$ and In may act as a buffer for $\mathrm{Cu}$ diffusion as the $I-V$ curve had small light to dark cross over. However, the se may have alloyed with the cas layer modifying its properties by forming a cd(sSe) alloy.

4) All structures adhered to the substrates with the exception of $\mathrm{Se} / \mathrm{Cu} / \mathrm{In}$ where $\mathrm{Cu}_{3} \mathrm{Se}_{2}$ was formed at room temperature.

5) Several back contacts have been examined with promising results obtained with a carbon contact. 
The majority of the research, however, was focused on selenization as discussed below. Cu-In bilayers were reacted

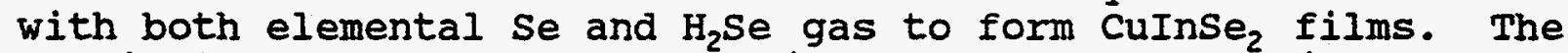
chemical pathways to the formation of the CuInSe $\mathrm{C}_{2}$ using $\mathrm{Se}$ and $\mathrm{H}_{2} \mathrm{Se}$ were evaluated and compared. An ultra clean $\mathrm{H}_{2}$ Se system was designed and built and will be used to evaluate the effect of impurities on the selenization reaction. Thermodynamic calculations for the dissociation of $\mathrm{H}_{2} \mathrm{Se}$ were performed and a kinetic model developed based on pyrolysis experiments and literature data. Finally, devices with efficiency near 10\% were made.

\subsubsection{Glass substrate}

We have previously shown that CuInSe $/$ Cas devices on soda lime glass have better cell performance than devices on 7059 glass. This difference was attributed to a better thermal expression match. We have evaluated both drawn and float soda lime glass. Drawn soda-lime glass was originally used as substrates for Cu/In layers for selenization. Hazy films appeared on the glass slides and in Mo and CuInSe ${ }_{2}$ films deposited on the glass as little as one week after deposition or cleaning, and became more apparent over time. This drawn glass is rich in sodium, which is very mobile and reactive. It was speculated that the sodium was migrating to the glass surface, possibly reacting to form sodium halides, and leeching into deposited films, causing their cloudy and non-uniform appearance.

Soda-lime float glass is presently being used and has eliminated this problem. This type of soda-lime glass has a much more durable surface than the drawn type, and sodium migration should be minimal. No haze on the glass or films has been observed. During fabrication of the glass, it is floated on a tin bath, causing one side of the glass to be tin-rich. The tin side of the glass glows 'whiter' than the non-tin side when viewed on a dark surface with a short-wave ultraviolet lamp. This method is used to identify the different sides of the glass, and sputtered Mo films deposited on the non-tin rich surface for substrates are stable.

Some adherence problems have been encountered, mainly with thicker ( $>1 \mu \mathrm{m}$ ) Mo films. For this reason, an intermediate layer of 2000 $\AA$ ITO is first deposited on the glass, followed by the Mo film. sputtering conditions for Mo have also been modified to reduce apparent stress-related defects in the films (30). Some unavoidable surface defects of the glass can be seen on the glass/ITO/Mo substrates, but films appear smooth, continuous, relatively pin-hole free, and adhere well to the glass during standard processing procedures.

3.1.2. Deposition and analysis of $\mathrm{Cu}$-In layers for selenization

Cu-In layers with molar ratios from 0.85 to 1.1 were deposited by 
electron beam evaporation on glass/Mo substrates: The $\mathrm{Cu}$ deposition rate, $15 \mathrm{~A} / \mathrm{sec}$, was chosen to minimize spits from the source which resulted in localized regions of high $\mathrm{Cu}$ on the substrate. The In was deposited at $20 \AA / \mathrm{sec}$. The thickness, and thus the $\mathrm{Cu}$ to In ratio, was monitored with a quartz crystal monitor. Additionally, the following procedure was developed to evaluate the $\mathrm{Cu} / \mathrm{In}$ ratio of $\mathrm{Cu} / \mathrm{In} / \mathrm{Mo}$ films after the e-beam deposition:

1. The $\mathrm{Cu}$ thickness was fixed at about $250 \mathrm{~nm}$ (based on Kronos thickness) and the $\mathrm{Cu} / \mathrm{In}$ ratio was varied by changing the In thickness.

2. A Cu-In substrate was heat treated in flowing Ar for $30 \mathrm{~min}$ to insure that the $c u$ and In are intermixed and have formed an alloy.

3. Electron Dispersive Spectroscopy (EDS) measurements were performed at an electron beam energy of $30 \mathrm{keV}$ so that the $\mathrm{Cu}-\mathrm{K}, \mathrm{In}-\mathrm{L}$, Mo-K\&I $\mathrm{x}$-ray lines were detected.

4. The relative $\mathrm{Cu} / \mathrm{In}$ ratio was determined from the analysis of the $C u$ and In $x$-ray lines. The ratio of the Mo $K$ and $I$ $x$-ray lines provides a secondary measure of the relative thickness of the Cu-In film from run to run since these $x-$ ray lines are separated by $\sim 15 \mathrm{keV}$.

Figure 28 is a plot of the relative EDS $\mathrm{Cu} / \mathrm{In}$ ratio vs. the $\mathrm{Cu} / \mathrm{In}$ ratio based on the quartz crystal monitor used during the deposition. There is a reasonable linear correlation between the two ratios. The samples in the set shown in Figure 28 were also analyzed by atomic absorption spectroscopy to check the cu/In ratio in each of the layers. The final, and perhaps best, check of the Cu-In films was to selenize the films using elemental se under a set of standard conditions. The composition of the resulting film was then evaluated. For selenization experiments discussed in the following sections, the $\mathrm{Cu}$ thickness was $250 \mathrm{~nm}$ and the In thickness was varied to control the $\mathrm{Cu} / \mathrm{In}$ ratio.

Preliminary experiments were conducted to determine the effect of a Te inter-layer on metal precursor species and configuration as suggested in ref. 31. Thin, $\sim 1 \mathrm{~nm}$, Te layers were deposited electrochemically onto Mo/glass substrates followed sequentially by In and $C u$ layers, as suggested in the patent application. SEM and EDS evaluation (see Figures 29 and 30) showed that the $\mathrm{Te} / \mathrm{In} / \mathrm{Cu}$ films were more uniform and defect free compared to In/Cu layers deposited directly on Mo. Selenization of the Te/In/Cu films in Se and subsequent fabrication of devices showed no difference in performance compared to a Mo/Cu/In configuration. 


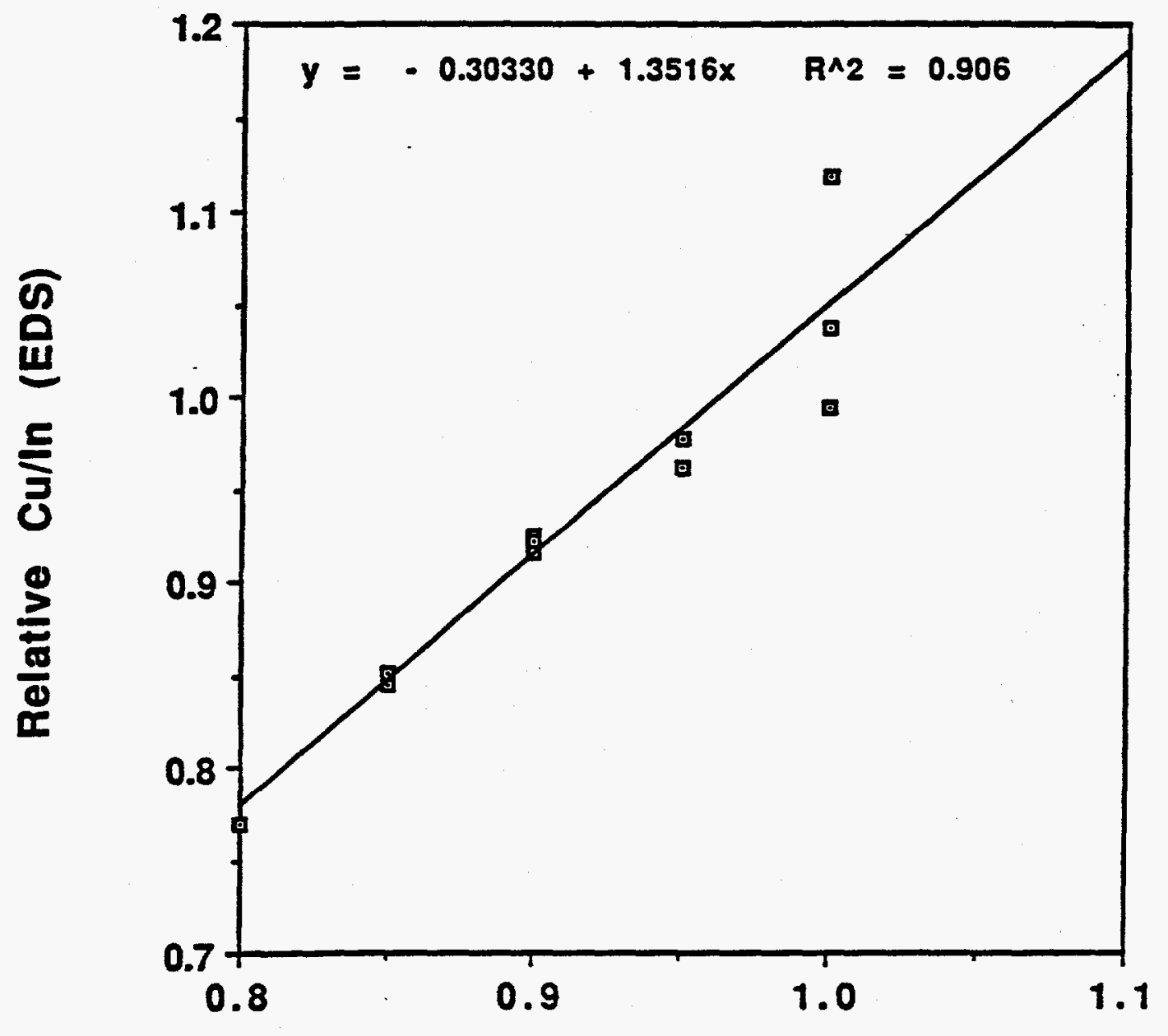

Cu/In (crystal monitor)

Figure 28. Relative ratio of cu/In ratio determined by EDS 

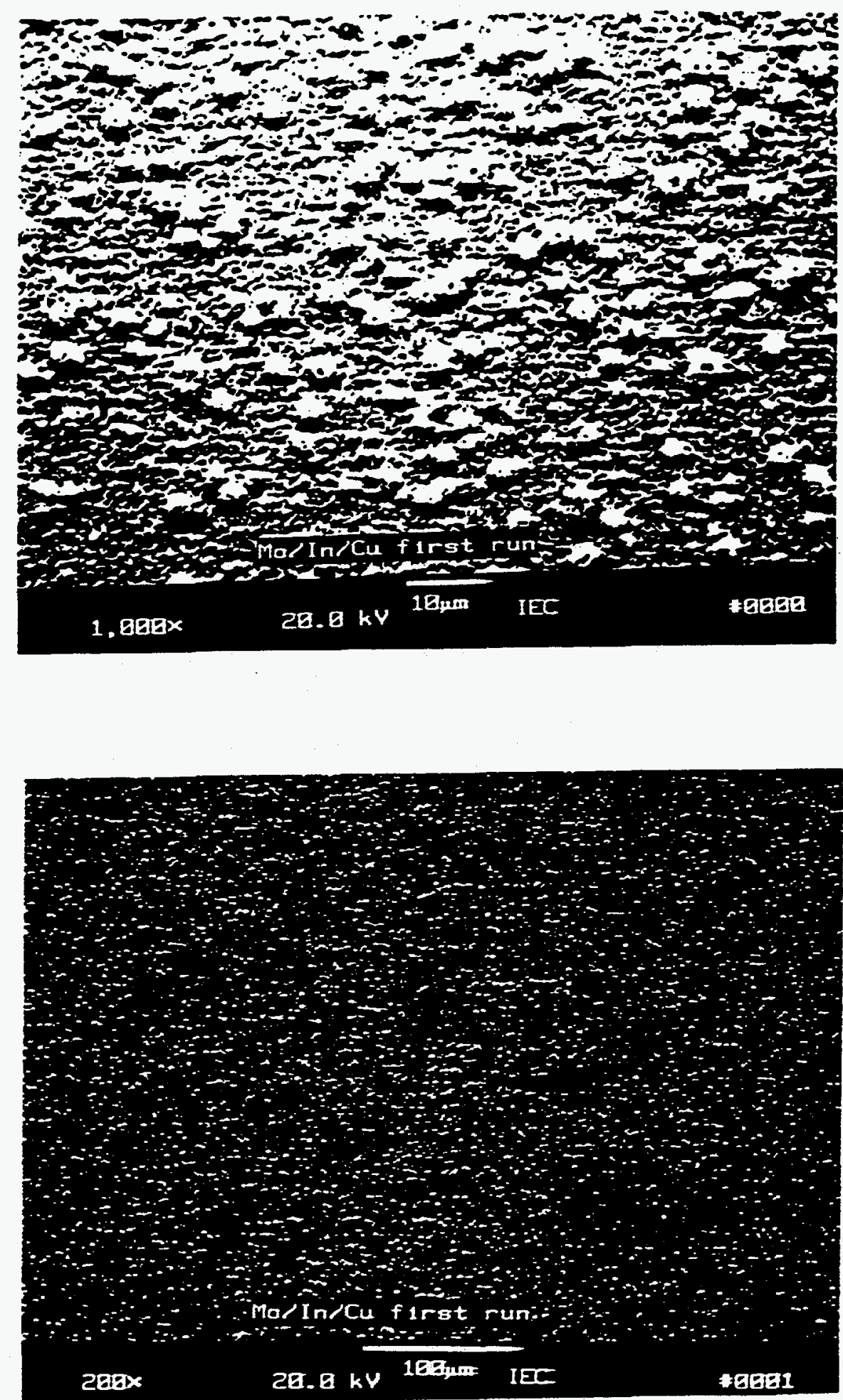

Figure 29. SEM micrographs of MO/In/Cu layer. 

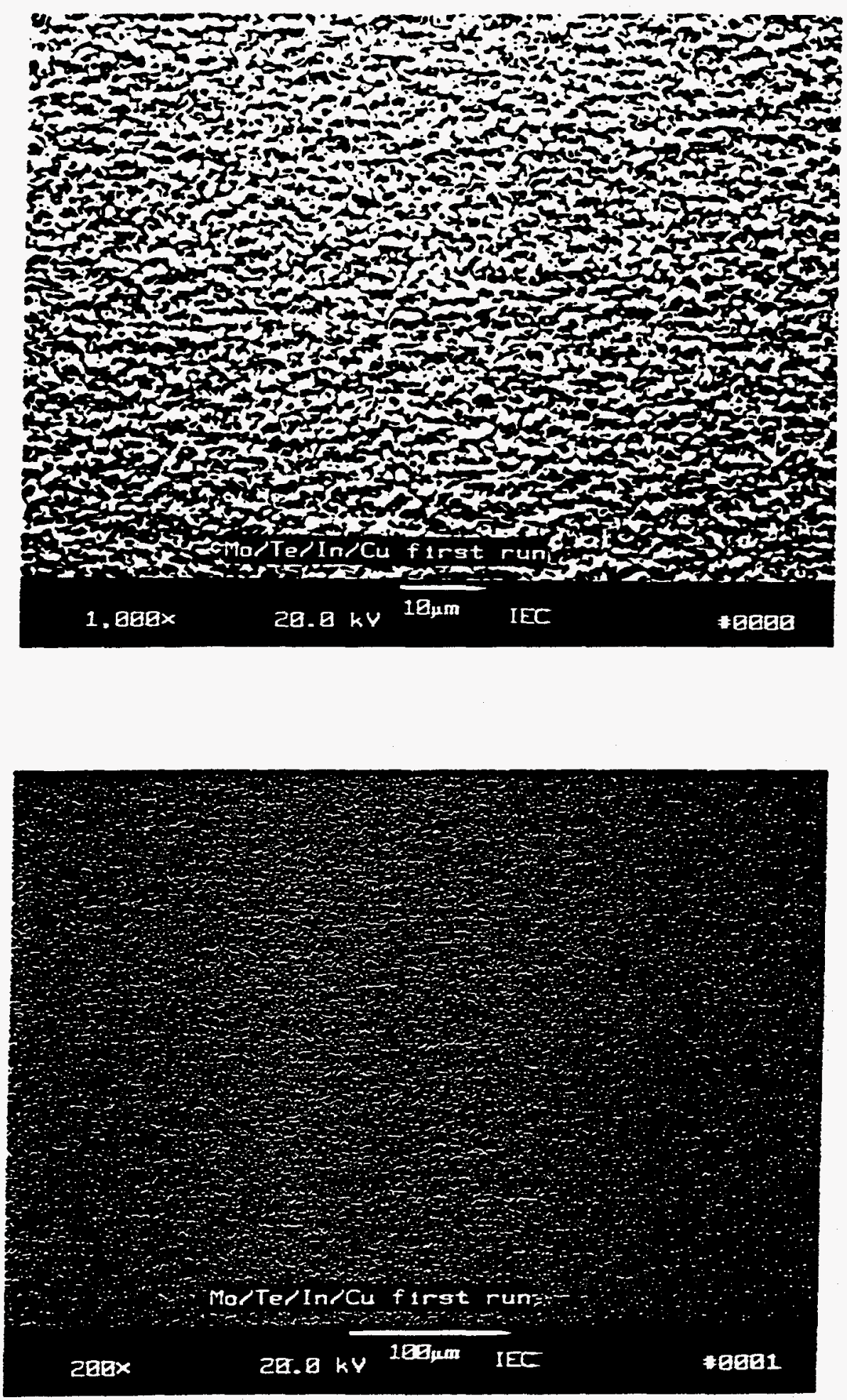

Figure 30. SEM micrograph of Mo/Te/In/Cu layer. 
Further work is needed to improve the reproducibility and spatial uniformity of the thin Te layer deposition. The effects of a Te inter-layer on devices with cuInse, formed by selenization will then be investigated further. The inverted bi-layers and $\mathrm{a} T \mathrm{Te}$ inter-layer are expected to be of interest in connection with fabrication of superstrate cuInse, devices.

\subsection{3. $\mathrm{H}_{2} \mathrm{Se}$ Reaction System}

A new selenization reaction system using $\mathrm{H}_{2} \mathrm{Se}$ was designed and built and a schematic drawing of the system is shown in Fig. 31. The reaction takes place in a $2^{\prime \prime}$ diameter heated quartz tube with a -4 " uniform temperature zone. The system was designed to be 'ultra clean' so that the effects of gas impurities, such as $\mathrm{O}_{2}$ and $\mathrm{H}_{2} \mathrm{O}$, could be studied. The system is equipped with a turbomolecular pump and a residual gas analyzer (RGA). Baseline data on the cleanliness of the system was obtained from RGA measurements with the system pumped below $2 \times 10^{-6}$ torr under the following conditions:

1. With the reactor empty and heated to $400^{\circ} \mathrm{C}$, this data will be used as the "signature" for a clean system.

2. With a graphite substrate holder, the RGA data showed significant amounts of high molecular species evolving from the graphite. Based on these results and problems encountered in the past with the graphite, we have decided not to use a substrate holder.

3. With $\mathrm{Cu} / \mathrm{In}$ substrates, out-gassing of the substrates, primarily water, is initially high but after an overnight pumping the RGA spectrum returns to background levels. For selenization experiments, the substrates can be pumped overnight to insure a "clean" system before starting.

The effects of heating $\mathrm{Cu} /$ In layers in the clean turbular reactor with flowing $\mathrm{H}_{2} / \mathrm{Ar}$ were evaluated for temperatures of 200 and $400^{\circ} \mathrm{C}$ for $20 \mathrm{~min}$. At $200^{\circ} \mathrm{C}$, the surface morphology of the $\mathrm{Cu} / \mathrm{In}$ layer 


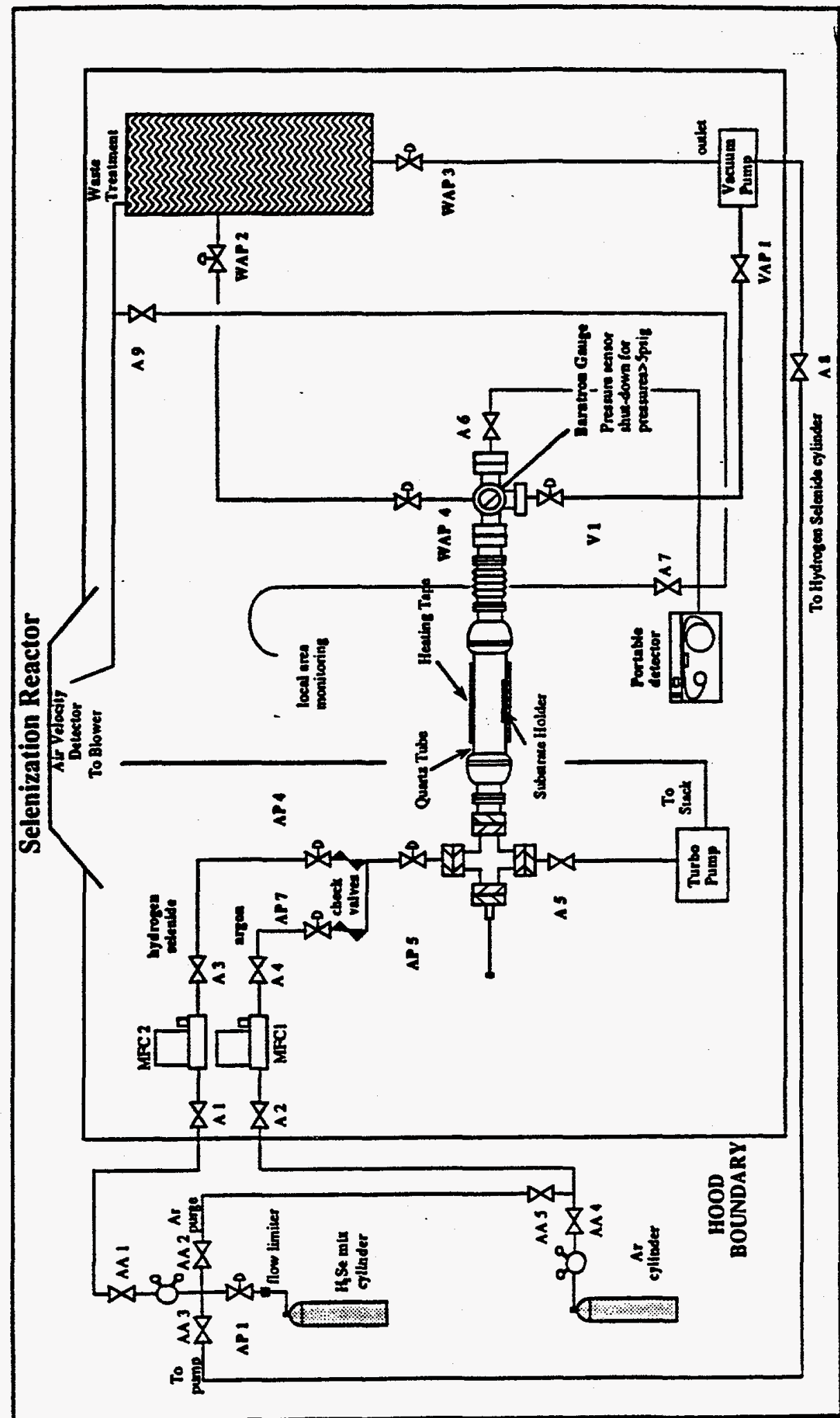

8
0
0
0
0
0
0
0
0
0
0
0
0
0
0
0
+1
0
0
0
0
0
0

i

है 
was unchanged but the phases present were changed from initially $\mathrm{Cu}$, In, and $\mathrm{CuIn}_{2}$ to In and $\mathrm{Cu}_{11} \mathrm{In}_{9}$. After the system was at $200^{\circ} \mathrm{C}$ for $-20 \mathrm{~min}$ the RGA spectrum was comparable to that following an overnight pump down suggesting that heat treatment of the films can be used instead of on overnight pump down. A dramatic change was seen in the surface morphology after heating at $400^{\circ} \mathrm{C}$. Islands of $\mathrm{Cu}$-In formed, exposing the Mo in the regions between the islands. From XRD, the structure consisted of $\mathrm{In}$ and $\mathrm{Cu}_{19} \mathrm{In}_{9}$. This is significantly different from what we reported previously in our old system where the starting morphology of the films was preserved. We speculate that this difference in morphology between the two systems is due to the amount of oxide on the film surface. That is, in the new system, either surface oxides are reduced or are not formed during the heat treatment as a result of pumping to remove residual water and the use of $\mathrm{H}_{2} / \mathrm{Ar}$. The old system may have had oxygen in the Ar gas or leaks in the system to atmosphere.

\subsection{4. $\mathrm{H}_{2}$ Se Chemistry}

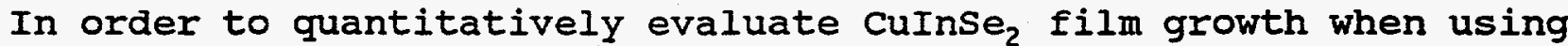
$\mathrm{H}_{2} \mathrm{Se}$ gas and to design an efficient commercial scale reaction system it is necessary to know the gas phase species and relative concentrations due to $\mathrm{H}_{2} \mathrm{Se}$ pyrolysis. To determine this, thermodynamic calculations for the dissociation of $\mathrm{H}_{2} \mathrm{Se}$ were performed and a kinetic model developed based on our pyrolysis experiments and literature data. A complete discussion of these calculation and results is included in Appendix A.

$\mathrm{H}_{2} \mathrm{Se}$ is a colorless, extremely toxic gas, whose decomposition products have been identified as polymeric se species $(35,36)$. When $\mathrm{H}_{2} \mathrm{Se}$ is used for selenization, both $\mathrm{H}_{2} \mathrm{Se}$ and the product selenium species are available for reaction with the $\mathrm{Cu} /$ In layer to

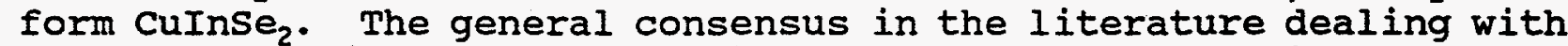
the thermolysis or pyrolysis of hydrogen selenide is that the following overall reaction governs its decomposition $(36,37)$ :

$$
\mathrm{H}_{2} \mathrm{Se} \longleftrightarrow->\mathrm{H}_{2}+1 / 2 \mathrm{Se}_{2}
$$

The reaction is endothermic with an enthalpy change $\Delta \mathrm{H}_{298}^{\circ}=9.7$ $\mathrm{kcal} / \mathrm{mole}$ and a free energy change $\Delta \mathrm{H}^{\circ}{ }_{298}=14.46 \mathrm{kcal} / \mathrm{mole}$ (32). only a limited amount of research on the reaction order and rate constants has been performed (17).

At equilibrium, over the temperature range important for selenization of copper indium bilayers, the gas phase consists of about $50 \% \mathrm{Se}_{2}$ and $\mathrm{Se}_{6}$ and $50 \% \mathrm{H}_{2} \mathrm{Se}$. At $450 \% \mathrm{C}$, it takes about 10 minutes to reach equilibrium, which is about the same time that it takes to form CuInse $e_{2}$. At short times (less than 10 minutes) the rate of dissociation of $\mathrm{H}_{2} \mathrm{Se}$ is directly proportional to its concentration. The reverse reaction becomes increasingly important as time increases. The forward rate constant $k_{f}$ was calculated to be $1.0 \times 10^{9} \exp \left(-E_{a} / R T\right)$ where $E_{a}=39.96 \mathrm{kcal} / \mathrm{mol}$. Kinetic 
experiments on the pyrolysis of $\mathrm{H}_{2} \mathrm{Se}$ show that a reasonable fit to the data can be obtained by assuming $\mathrm{Se}_{6}$ as the decomposition product.

\subsubsection{Se Reaction System}

A process was developed for selenizing $\mathrm{Cu}$-In layers to form $\mathrm{CuInSe}_{2}$ using elemental Se. A vacuum system was set-up with a open quartz crucible to evaporate se and a substrate heater system which holds an array of nine one inch substrates. Initial experiments consisted of heating $\mathrm{Cu}-\mathrm{In} / \mathrm{Mo} / \mathrm{glass}$ substrates to $400^{\circ} \mathrm{C}$ without $\mathrm{Se}$ for approximately 30 minutes. The substrates, still at $400^{\circ} \mathrm{C}$, were then exposed for 60 minutes to a flux of se. Micrographic examination of the resulting films revealed unconnected islands of CuInSe $_{2}$. These findings are similar to those discussed above for $\mathrm{Cu}-$ In films reacted with $\mathrm{H}_{2} \mathrm{Se}$ under conditions where superficial oxides were eliminated.

When the Se is deposited at room temperature, continuous films of $\mathrm{CuInSe}_{2}$ are produced. A set of $\mathrm{Cu}$-In layers with ratios from 0.8 to 0.9 were selenized in a vacuum system using the following deposition sequence: 1) $1 \mu \mathrm{m}$ of $\mathrm{Se}$ was deposited at $10 \mathrm{~A} / \mathrm{sec}$ with the substrates at room temperature, 2) the samples were then heated to an intermediate reaction temperature in the presence of se vapor and held at this temperature for $15 \mathrm{~min}, 3$ ) the samples were heated to $400^{\circ} \mathrm{C}$ in the presence of se and reacted for $1 \mathrm{hr}$, and 4) samples were cooled to room temperature $(-3 \mathrm{hr})$. For this set of experiments, four different intermediate reaction temperatures were used - $150^{\circ} \mathrm{C}$ (below In melting temperature), $200^{\circ} \mathrm{C}$ (below Se melting temperature) 250 (above In and se melting temperatures and $400^{\circ} \mathrm{C}$. The samples were evaluated by EDS, SEM and XRD prior to fabricating devices. The results can be summarized as follows:

1. The composition of the films was independent of the intermediate reaction temperature and ranged from $\mathrm{Cu}=22$ to $24 \%$, In $=25$ to $28 \%$ and $S e=48$ to $53 \%$. XRD scans (not done on all samples) showed only peaks due to $\mathrm{CuInSe}_{2}$.

2. With the exception of the films reacted using the $200^{\circ} \mathrm{C}$ intermediate temperature, the appearance of the films were similar having a regular morphology similar to the starting $\mathrm{Cu} / \mathrm{In}$ layer. The films reacted at $200^{\circ} \mathrm{C}$ (above the melting point of In), had smaller and irregular grain structures.

3. Films selenized using either a 200 or $250^{\circ} \mathrm{C}$ intermediate temperature tend to have adherence problems which were apparent either when removing the samples from the deposition chamber or during subsequent cell fabrication.

Several CuInSe $/$ (CdZn)S cells with efficiencies > $9 \%$ have been made using this procedure. Cell results are summarized in Table 6 and the spectral response of cell $61067-11$ is shown in Fig. 32. The CuInse $_{2}$ films in these devices were formed with the se deposited on the substrate at room temperature, followed by a $15 \mathrm{~min}$. 


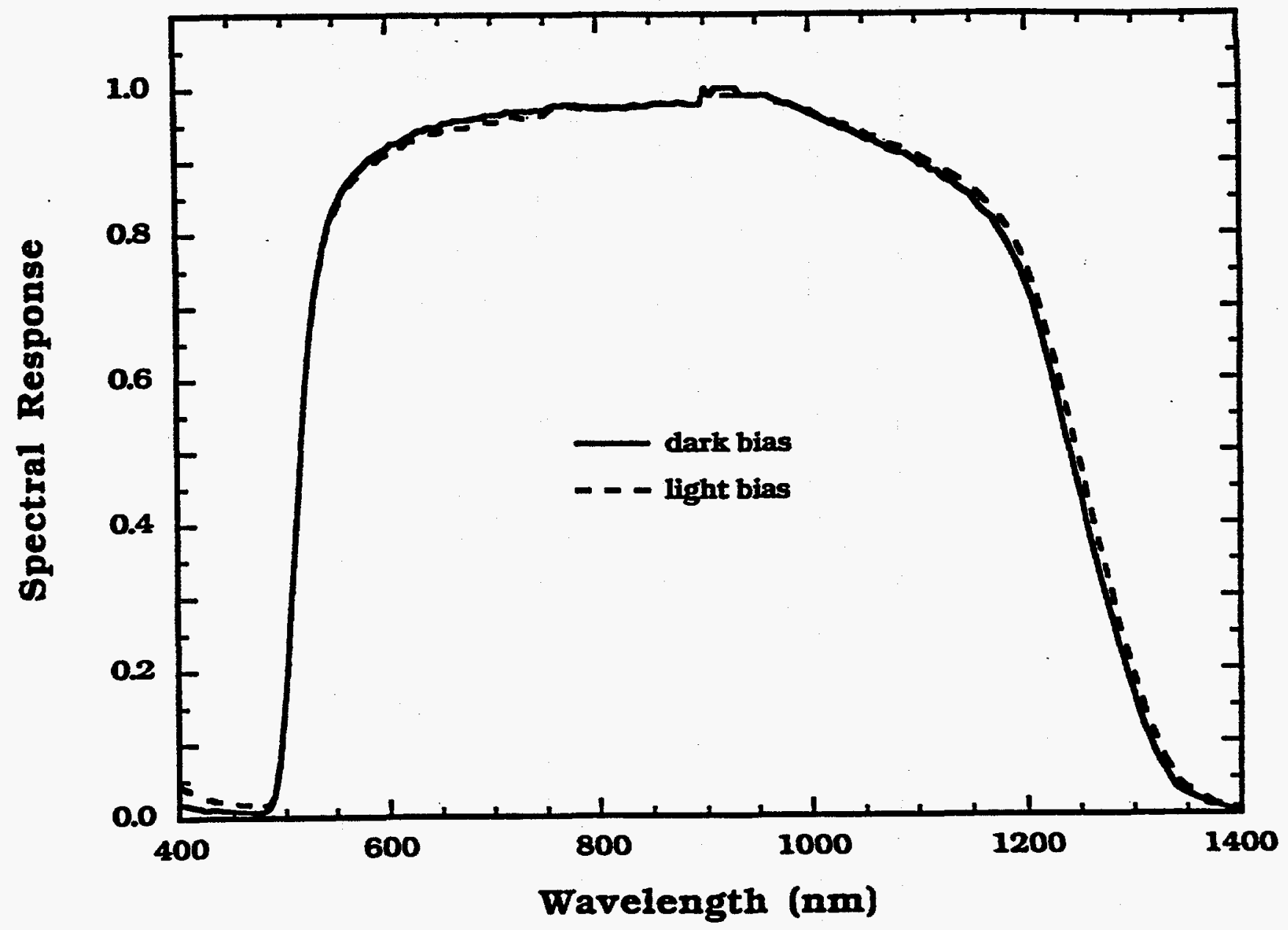

Figure 32. Normalized spectral response curve for a cuInse /cas cell using a cuInse, film grown by selenization using elemental se. 
intermediate reaction with the substrate temperature $\mathrm{T}_{\mathrm{ss}}=150^{\circ} \mathrm{C}$, and then reaction for $60 \mathrm{~min}$. at $\mathrm{T}_{\mathrm{ss}}=400$ or $450^{\circ} \mathrm{C}$. At each reaction temperature, $\mathrm{Cu} / \mathrm{In}$ layers with different compositions were included. Comparable cell results were obtained from the films with $\mathrm{Cu} / \mathrm{In}=0.85$ and 0.90 . These cells all required 16 hour, $200^{\circ} \mathrm{C}$ heat treatments in air to optimize the cell performance similar to cells with CuInSe, deposited by elemental evaporation.

Table 6

Summary of $I-V$ Results for CuInSe $/$ CdS Cells Using CuInSe ${ }_{2}$ Films Grown by Selenization

$\begin{array}{llllllr}\# & \begin{array}{c}\text { initial } \\ \text { Cu/In }\end{array} & \begin{array}{c}\mathrm{T}_{\text {ss }} \\ \left({ }^{\circ} \mathrm{C}\right)\end{array} & \begin{array}{c}\mathrm{V}_{\text {oc }} \\ (\mathrm{V})\end{array} & \begin{array}{c}\mathrm{J}_{\text {sc }} \\ \left(\mathrm{mA} / \mathrm{cm}^{2}\right)\end{array} & \begin{array}{l}F F \\ (\%)\end{array} & \begin{array}{r}\text { Eff. } \\ (\%)\end{array} \\ 61066-12 & 0.85 & 400 & 0.420 & 34.7 & 59.6 & 8.7 \\ 61066-11 & 0.90 & 400 & 0.424 & 30.3 & 60.7 & 7.8 \\ 61067-12 & 0.85 & 450 & 0.403 & 33.7 & 62.9 & 8.5 \\ 61067-11 & 0.90 & 450 & 0.404 & 35.4 & 61.0 & 8.7 \\ 61067-13 & 0.95 & 450 & 0.28 & 29.4 & 53.3 & 4.4\end{array}$

\subsubsection{Chemical Pathways to Formation of CuInSe $_{2}$}

The reaction pathways and the chemical precursors to formation of $\mathrm{CuInSe}_{2}$ are evaluated by reacting single layers of $\mathrm{Cu}$ and $\mathrm{In}$ and $\mathrm{Cu}$-In bilayers with flowing $\mathrm{H}_{2} \mathrm{Se}$ at atmospheric pressure and in the evaporator using an elemental se source. In both systems, the selenizations were carried out at temperatures ranging from $150^{\circ} \mathrm{C}$ to $400^{\circ} \mathrm{C}$ for 60 minutes. The reacted films were then analyzed and the reaction schemes were evaluated for the two reacting systems.

Copper and indium single layers with thicknesses of $250 \mathrm{~nm}$ and $560 \mathrm{~nm}$, respectively, and copper-indium bilayers with a total thickness of $810 \mathrm{~nm}$ with a molar ratio of about 0.9 were used as substrates for the experiments. When using $\mathrm{H}_{2} \mathrm{Se}$, the substrates were annealed in vacuum for 20 minutes at $150^{\circ} \mathrm{C}$ prior to selenization to alloy the $\mathrm{Cu}$ and In and "clean the system". The operating conditions in the tubular reactor were selected based on results on the $\mathrm{H}_{2} \mathrm{Se}$ chemistry to ensure that only $\mathrm{H}_{2} \mathrm{Se}$ was present, i.e., there was no decomposition to se species. When using elemental Se, lo00nm of Se were deposited on the Cu-In layer at room temperature prior to the reaction. The two selenization methods provide a comparison of the reaction with $\mathrm{H}_{2} \mathrm{Se}$ and $\mathrm{Se}$ vapor and its effect on the film morphology. The samples were examined by optical microscopy, SEM and XRD. 
Both $\mathrm{Se}$ and $\mathrm{H}_{2} \mathrm{Se}$ react with copper at room temperatures and above to form $\mathrm{Cu}_{(2-x)}$ Se. A single indium layer undergoes reaction in $\mathrm{H}_{2} \mathrm{Se}$ only at temperatures greater than $150^{\circ} \mathrm{C}$. An indium layer selenized at $250^{\circ} \mathrm{C}$ is converted to $\mathrm{In}_{2} \mathrm{Se}$ and InSe. Above $350^{\circ} \mathrm{C}$, $\mathrm{In}_{2} \mathrm{Se}_{3}$ is the dominant phase.

Table 7 summarizes the phases identified at various temperatures for $\mathrm{Cu}$-In bilayers in the two reacting systems. The key features are:

1. From $150^{\circ} \mathrm{C}$ to $300^{\circ} \mathrm{C}$, films contain $\mathrm{Cu}_{11} \mathrm{In}_{9}$, independent of the method of selenization, suggesting that the reaction has not gone to completion.

2. From $200^{\circ} \mathrm{C}$ to $350^{\circ} \mathrm{C}$, the films contain $\operatorname{In}_{2} \mathrm{Se}$ and Inse, independent of the method of selenization.

3. Copper selenide is only formed when using se at temperatures above $170^{\circ} \mathrm{C}$.

4. CuInse $e_{2}$ is formed above $170^{\circ} \mathrm{C}$ in Se and above $250^{\circ} \mathrm{C}$ in $\mathrm{H}_{2} \mathrm{Se}_{\mathrm{x}}$ ' implying the rate of formation of CuInse $_{2}$ is faster in se.

5. At $400^{\circ} \mathrm{C}$, the $\mathrm{Cu}$-In bilayers are completely converted to $\mathrm{CuInSe}_{2}$ in either reacting system.

6. The Cu-In bilayers selenized in the evaporator appear to retain the peanut configuration (of the as-deposited indium on copper) at temperatures less than $250^{\circ} \mathrm{C}$.

7. The $\mathrm{Cu}$-In bilayers selenized in the tubular reactor using $\mathrm{H}_{2} \mathrm{Se}$ do not retain the peanut configuration at temperatures greater than $250^{\circ} \mathrm{C}$ as previously. 
Table 7

Summary of Phases Identified by XRD for $\mathrm{Cu} /$ In Layers

Selenized in Elemental Se and $\mathrm{H}_{2} \mathrm{Se}$ for Temperatures From 150 to $400^{\circ} \mathrm{C}$

\begin{tabular}{|c|c|c|}
\hline $\begin{array}{l}\text { Reaction } \\
\text { Temperature }\end{array}$ & Reaction in $\mathrm{H}_{2} \mathrm{Se}$ & Reaction in se \\
\hline As Deposited & Cu, In, cuIn & $\mathrm{Cu}, \begin{array}{l}\text { In, CuIn (Se } \\
\text { amorphous) }\end{array}$ \\
\hline $150^{\circ} \mathrm{C}$ & $\mathrm{Cu}_{11} \mathrm{In}_{9}, \mathrm{In}, \mathrm{In}_{2} \mathrm{Se}$ & \\
\hline $170^{\circ} \mathrm{C}$ & & $\begin{array}{c}\mathrm{Cu}_{11} \mathrm{In}_{9}, \text { In, } \operatorname{In}_{2} \mathrm{Se}, \\
\text { CuInse }\end{array}$ \\
\hline $200^{\circ} \mathrm{C}$ & & 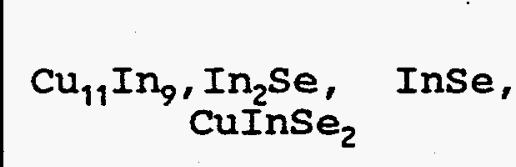 \\
\hline $250^{\circ} \mathrm{C}$ & $\begin{array}{c}\mathrm{Cu}_{11} \mathrm{In}_{9}, \mathrm{In}_{2} \mathrm{Se} \\
\text { cuInSe }_{2}, \text { In }\end{array}$ & $\begin{array}{l}\mathrm{Cu}_{11} \mathrm{In}_{9}, \mathrm{In}_{2} \mathrm{Se}, \\
\text { Inse, } \underset{\mathrm{Cu}_{7} \mathrm{Se}_{4}}{\mathrm{Cu}_{4}},\end{array}$ \\
\hline $300^{\circ} \mathrm{C}$ & & $\begin{array}{c}\text { CuInse }, \text { Inse, } \\
\mathrm{Cu}_{11} I n_{9}\end{array}$ \\
\hline $350^{\circ} \mathrm{C}$ & $\begin{array}{l}\text { CuInSe }_{2} \text { ' Inse, } \\
\text { In }_{2} \mathrm{Se}, \mathrm{Cu}_{11} \mathrm{In}_{9}\end{array}$ & \\
\hline $400^{\circ} \mathrm{C}$ & CuInSe $_{2}$ & CuInSe $_{2}$ \\
\hline
\end{tabular}


The postulated chemistry of selenization of the bilayers in $\mathrm{H}_{2} \mathrm{Se}$ is,

$$
\begin{array}{ll}
\mathrm{Cu}+\mathrm{In}-\rightarrow \mathrm{Cu}_{11} \mathrm{In}_{9} & 1 \\
\mathrm{In}+\mathrm{H}_{2} \mathrm{Se}-\rightarrow \mathrm{In}_{2} \mathrm{Se} & 2 \\
\mathrm{In} \mathrm{Se}_{2}+\mathrm{H}_{2} \mathrm{Se}->\mathrm{InSe} & 3 \\
\mathrm{Cu}_{11} \mathrm{In}_{9}+\mathrm{H}_{2} \mathrm{Se}->\mathrm{CuInSe} 2 . \\
\mathrm{Cu}_{11} \mathrm{In}_{9}+\mathrm{In}_{2} \mathrm{Se}+\mathrm{H}_{2} \mathrm{Se}->\mathrm{CuInSe}_{2} & 4 \\
\mathrm{Cu}_{11} \mathrm{In}_{9}+\mathrm{InSe}+\mathrm{H}_{2} \mathrm{Se}->\mathrm{CuInSe}_{2} & 6
\end{array}
$$

The proposed chemistry for selenization in se vapor is largely similar to the sequence of reactions noted above except that the reactant is $\mathrm{Se}$ instead of $\mathrm{H}_{2} \mathrm{Se}$. Additionally, the following reactions may be occurring in the film:

$$
\begin{array}{ll}
\mathrm{Cu}+\mathrm{Se}_{x}-\mathrm{Cu} \mathrm{Cu}_{7} \mathrm{Se}_{4} & 7 \\
\mathrm{Cu}_{7} \mathrm{Se}_{4}+{ }^{2} \mathrm{In}_{2} \mathrm{Se}+\mathrm{Se}_{\mathrm{x}} \rightarrow \mathrm{CuInSe}_{2} & 8 \\
\mathrm{Cu}_{7} \mathrm{Se}_{4}+\mathrm{InSe}+\mathrm{Se}_{x} \rightarrow \mathrm{CuInSe}_{2} & 9
\end{array}
$$

where the copper selenide phase (which may be $C u_{(2-x)}$ se or $\mathrm{Cu}_{7} \mathrm{Se}_{4}$ ) is formed.

The reaction pathways to $\mathrm{CuInSe}_{2}$ formation using either $\mathrm{H}_{2} \mathrm{Se}$ or Se proceed through the formation of the $\mathrm{Cu}_{19} I n_{9}$ phase and the indium selenide phases ( $\mathrm{In}_{2} \mathrm{Se}$ and InSe). The only different precursor in the two schemes is the copper selenide phase observed in the selenization in $\mathrm{Se}$ vapor. The reaction with Se also proceeds faster than the reaction with $\mathrm{H}_{2} \mathrm{Se}$. Below $400^{\circ} \mathrm{C}$ the phases observed in the reaction with $\mathrm{H}_{2} \mathrm{Se}$ at a temperature $\mathrm{T}$ are observed in the reaction with se at a temperature $\mathrm{T}-50^{\circ} \mathrm{C}$.

It appears, on a preliminary examination, that the binary

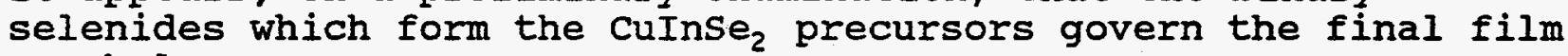
morphology.

\subsection{PROCESSING OF CATE DEVICES}

In this section, the relationship between individual processing steps used to fabricate CdTe/CdS solar cells and material and device properties are discussed. This can then be extended to other methods of fabricating cdTe/Cds solar cells. Previously reported work on the effects of high temperature processing and doping of CdTe will be reviewed and more recent work on the effects of cas thickness will be discussed.

The caTe/Cds devices were prepared in a superstrate configuration as shown in Figure 33. Undoped CdS films from 0.1 to $1.5 \mu \mathrm{m}$ thick were deposited by physical vapor deposition onto a glass/ITO or glass/ $\mathrm{SnO}_{2}$ substrate. In some cases, the cas was heat treated at $400^{\circ} \mathrm{C}$ for 20 to $30 \mathrm{~min}$. In air, with and without $\mathrm{CdCl}_{2}$ present prior to the deposition of the CaTe. Two $\mu \mathrm{m}$ thick cdTe films were deposited by physical vapor deposition at a 


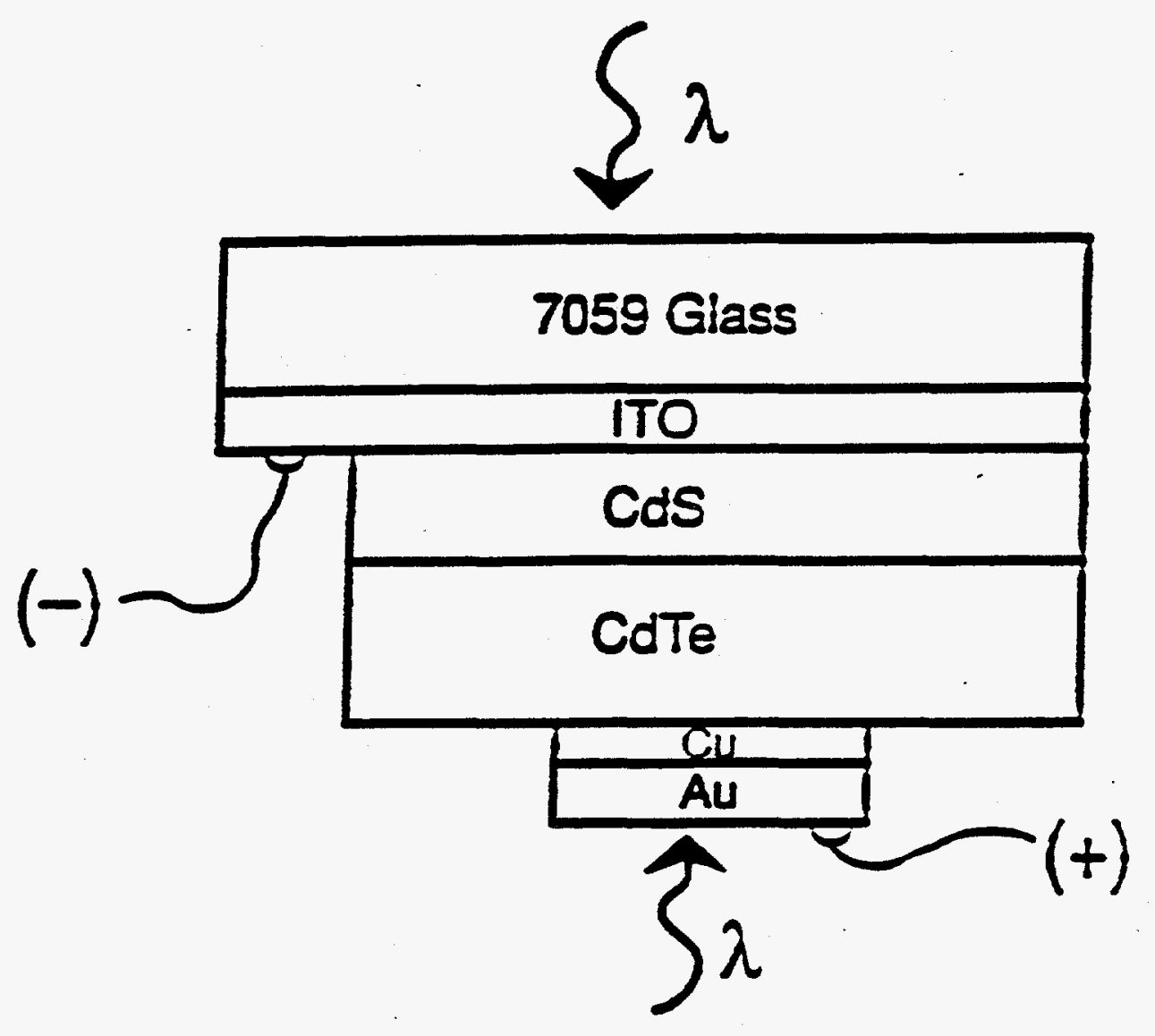

Figure 33. Schematic cross-section diagram of superstrate caTe/Cas device. 
substrate temperature of $250^{\circ} \mathrm{C}$. The samples were then heat treated in the presence of $\mathrm{CdCl}_{2}$ at $400^{\circ} \mathrm{C}$ for 20 to $30 \mathrm{~min}$. in air. The devices were completed by depositing a $\mathrm{Cu} / \mathrm{Au}$ contact followed by a $150^{\circ} \mathrm{C} 30 \mathrm{~min}$. heat treatment in air and a $\mathrm{Br}_{2} \mathrm{CH}_{3} \mathrm{OH}$ dip to optimize the device. A detailed description of the processing is presented in reference (23).

In fabricating the evaporated caTe/Cds solar cells, the $400^{\circ} \mathrm{C}$ $\mathrm{CdCl}_{2}$ heat treatment recrystallizes the CdTe and interdiffuses the Cds and cdTe layers. This interdiffusion changes the bandgap of the cdTe and cds which affects the spectral response of the solar cell. After this heat treatment a contacting/doping procedure is used which converts the caTe conductivity to p-type by diffusion of $\mathrm{Cu}$ using a $150^{\circ} \mathrm{C}$ heat treatment as discussed in Section 2.4. Finally, the devices receive a $\mathrm{Br}_{2} \mathrm{CH}_{3} \mathrm{OH}$ treatment increases both $V_{o c}$ and FF. These process steps and results are discussed in detail below.

\section{$3.2 .1400^{\circ} \mathrm{C} \mathrm{CaCl}{ }_{2}$ Heat Treatment}

A key step in fabricating high efficiency cells using a low temperature cdTe deposition process such as evaporation is the post deposition heat treatment at $400^{\circ} \mathrm{C}$ in air with $\mathrm{CdCl}_{2}$. This step increases the caTe grain size and promotes interdiffusion of the cds-caTe films $(16,24)$. The extent of the interdiffusion of the two films depends on the properties and thickness of the cas, as will be discussed below.

Figure 34 shows the XRD scans of a cdTe/CdS sample before and after the $400^{\circ} \mathrm{C} \mathrm{CaCl}$ heat treatment for $30 \mathrm{~min}$. and Table 8 summarizes analysis of the cdTe (111) peak. The shift and sharpening of the (111) XRD peak of the CdTe after heat treatment indicates that the majority of the diffracting layer was uniformly altered. The reduction in lattice parameter of the caTe is consistent with the formation of a $\operatorname{cdTe}_{1-x} s_{x}$ solid solution with approximately $3 \% \mathrm{~S}$ as we have previously reported $(16,24)$. The change in full width half maximum (FWHM) of the (1II) peak is consistent with an increase in grain size by a factor of 4 which was supported by scanning electron micrographs shown in Figures 35 and 36. Similar results have been observed by others (35).

The relative absorption coefficient of the caTe in a cdTe/cas sample before and after the $400^{\circ} \mathrm{C}$ heat treatment is shown in Figure 37. The decrease in the bandgap of the cate after the heat treatment is also consistent with the formation of a caTe $_{1-x} S_{x}$ layer where the caTe bandgap decreases with the addition of $S$ for $x<0.1$ (36). Thus, the $400^{\circ} \mathrm{C}$ heat treatment with $\mathrm{CdCl}_{2}$ results in the formation of a $\mathrm{CdTe}_{1-x} \mathrm{~S}_{x}$ layer with 


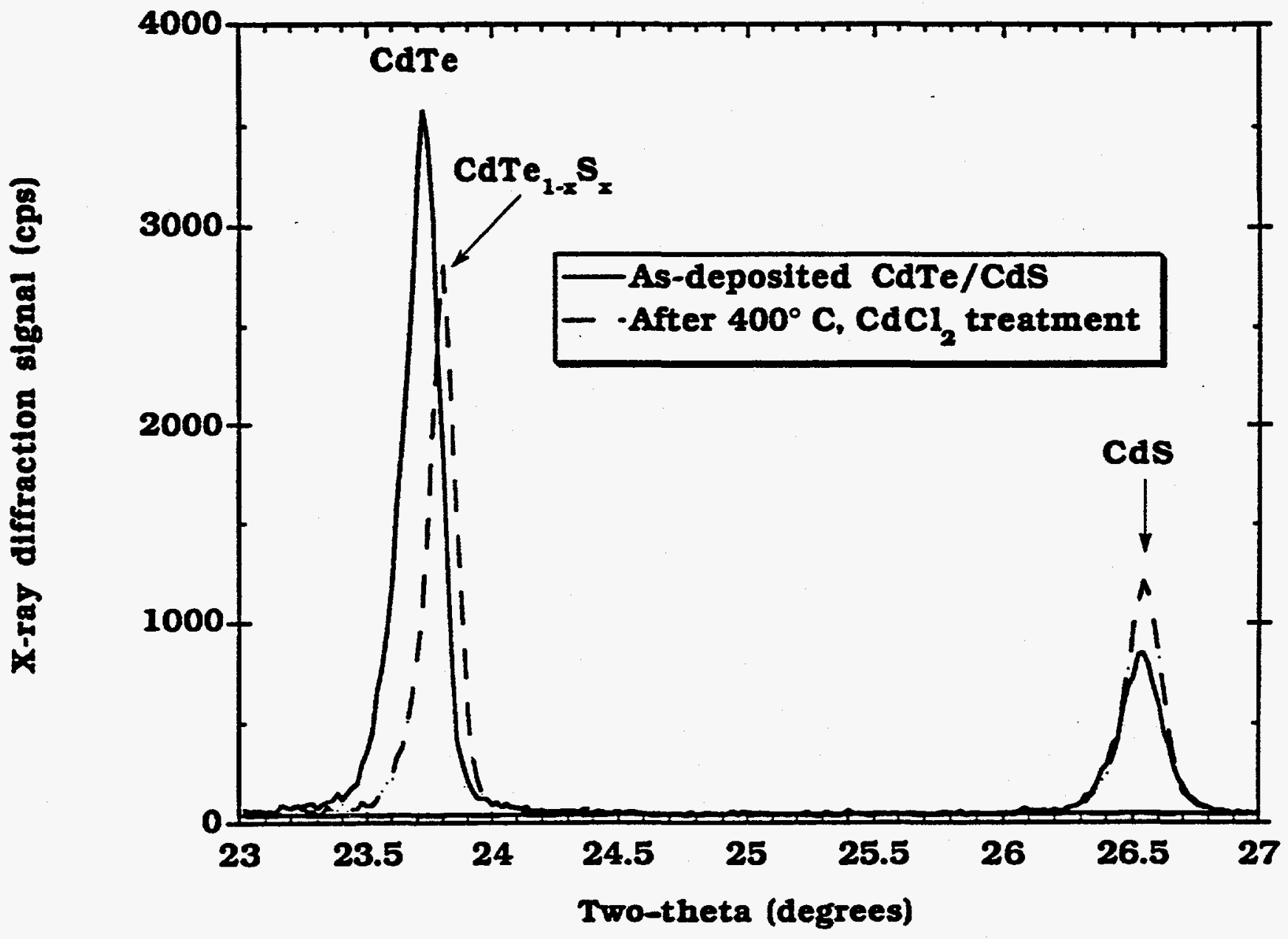

Figure 34. XRD scans before and after heat treatment at $400^{\circ} \mathrm{C}$ with $\mathrm{CdCl}_{2}$. The CdTe and Cds thicknesses were $2 \mu \mathrm{m}$ and $1 \mu \mathrm{m}$, respectively. 


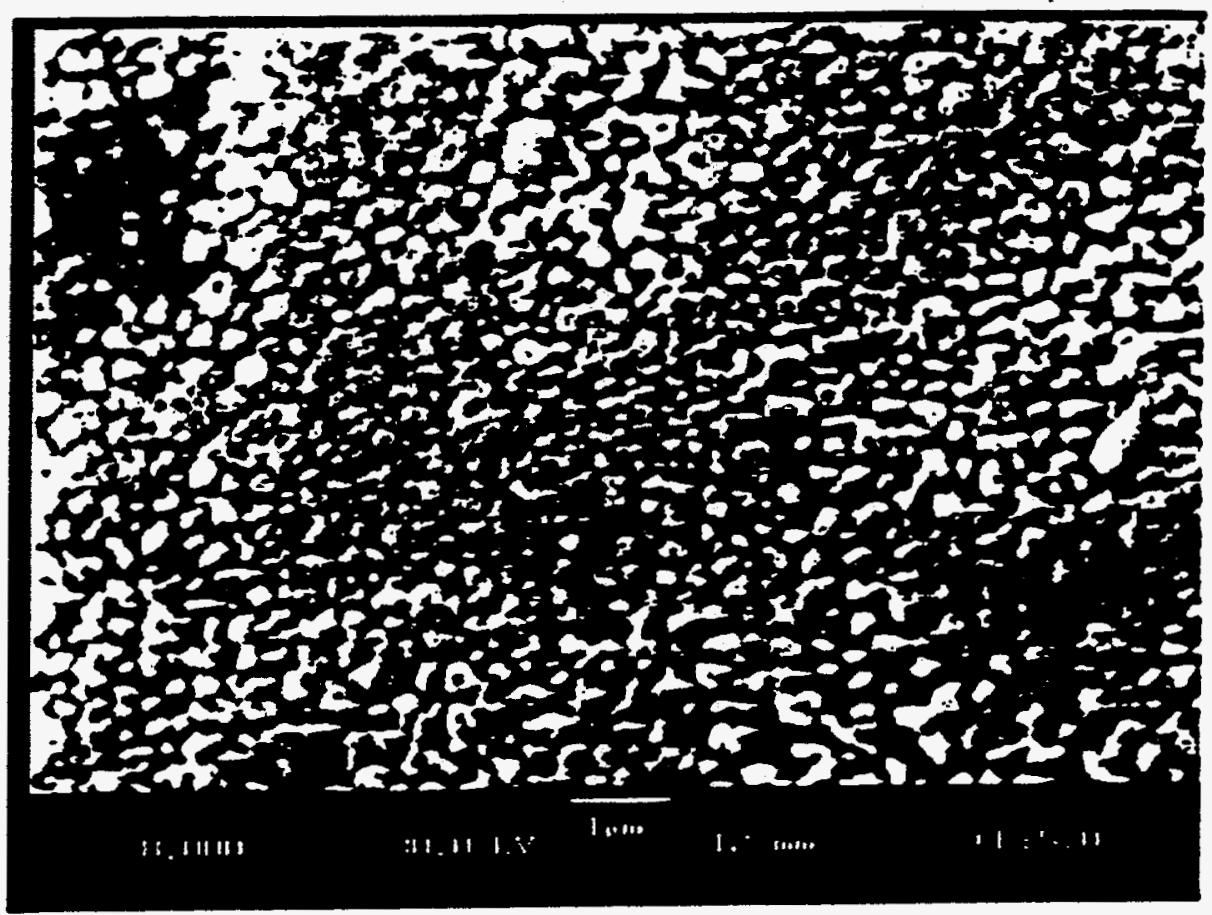

Figure 35. SEM photograph of the as-deposited CdTe surface. 


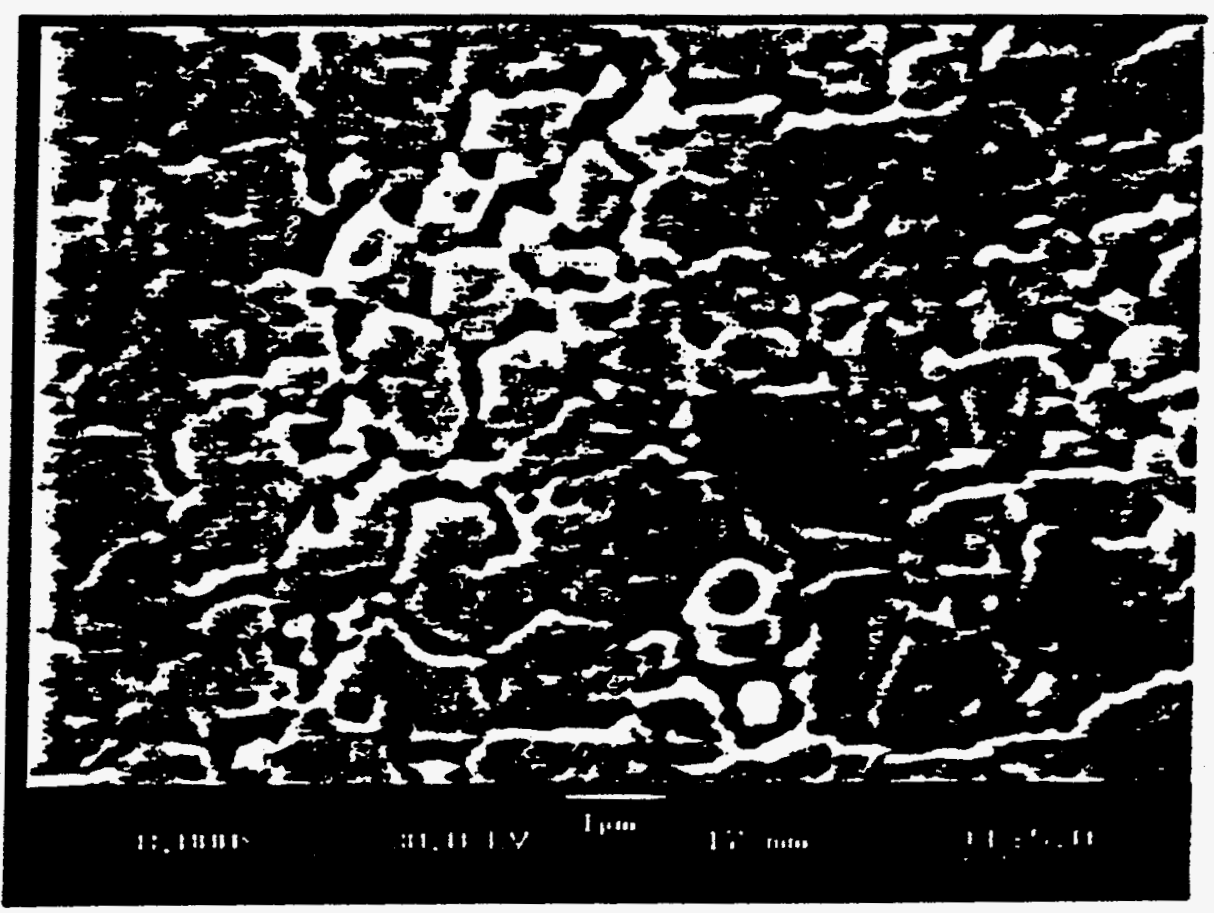

Figure 36. SEM photograph of the cate surface after heat treatment at $400^{\circ} \mathrm{C}$ with $\mathrm{CaCl}_{2}$. 


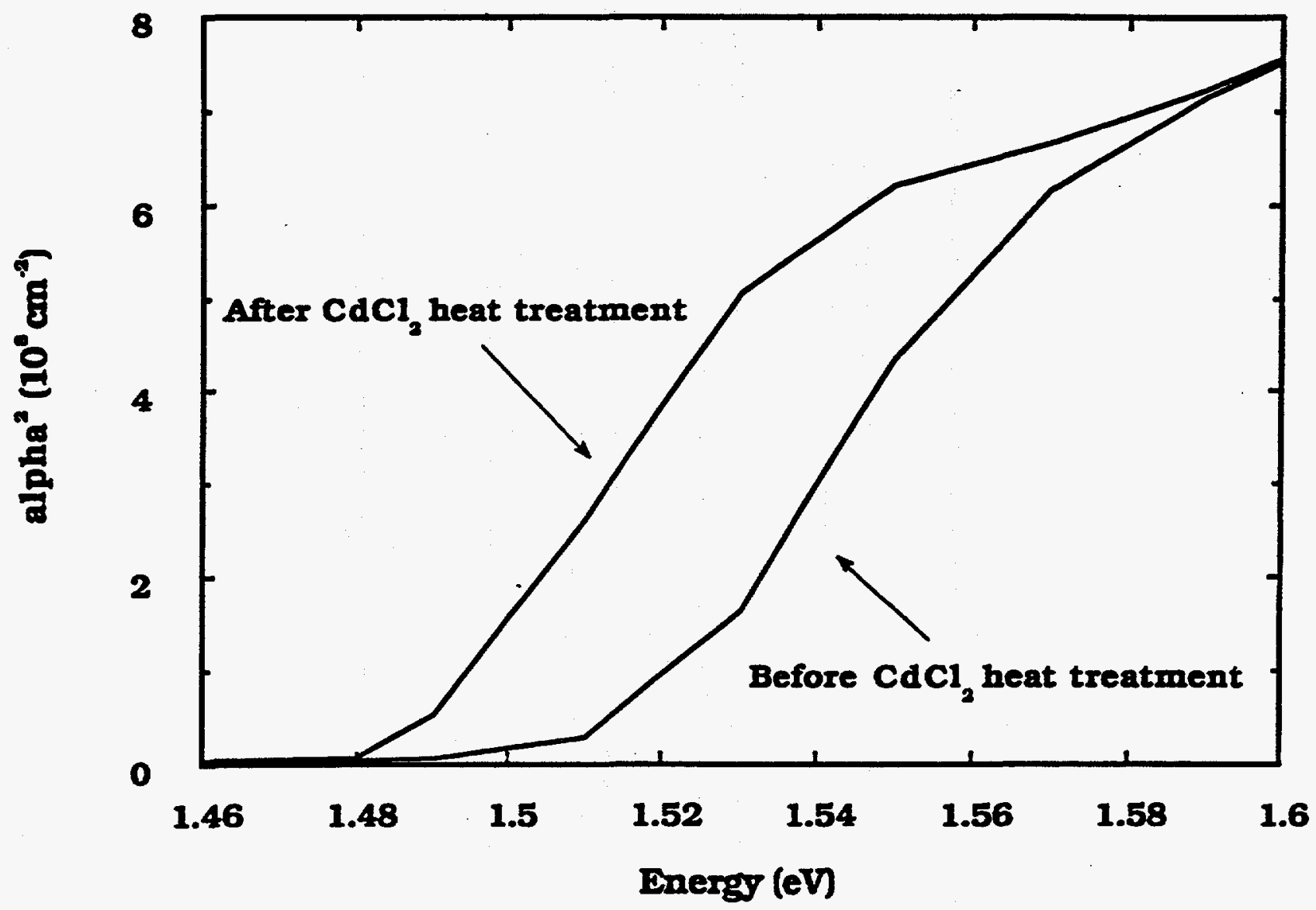

Figure 37. Comparison of the cate absorption edge in caTe/cds samples before and after heat treatment at $400^{\circ} \mathrm{C}$ with $\mathrm{CdCl}_{2}$. 
Table 8. XRD analysis of CaTe (111) peak before and after heat treatment at $400^{\circ} \mathrm{C}$ with $\mathrm{CdCl}_{2}$. The CdTe thickness was $2 \mu \mathrm{m}$.

$\begin{array}{lccc}\text { CaTe/Cas } & \begin{array}{c}\text { Lattice } \\ \text { Parameter } \\ (\AA)\end{array} & \text { FWHM } & \begin{array}{l}\text { Particle } \\ \text { Size } \\ (\AA)\end{array} \\ \text { As-deposited } & 6.497 & 0.065 & 1400 \\ \mathrm{CdCI}_{2} \mathrm{HT} & 6.475 & 0.011 & 8200\end{array}$

larger grain size and a decrease in the bandgap. Such changes do not occur at $400^{\circ} \mathrm{C}$ without $\mathrm{CdCl}_{2}(24)$.

Also consistent with formation of a $\mathrm{CdTe}_{1-x} \mathrm{~S}_{\mathrm{x}}$ layer is a decrease in effective cds thickness during processing. This is inferred from comparing the optical transmission of a glass/ $\mathrm{SnO}_{2} / \mathrm{CdS}$ sample to the spectral response of the same sample following cate deposition and $\mathrm{CdCl}_{2}$ treatment. Figure 38 shows the transmission (normalized by reflection losses) for an $800 \AA \mathrm{CdS}$ film and the spectral response of a device fabricated on the same sample. The response below $500 \mathrm{~nm}$ is significantly greater than the asdeposited cas transmission, which can be explained by a reduction of cas thickness during processing. For our $2.5 \mathrm{~cm} \times 2.5 \mathrm{~cm}$ substrates, a $2 \mu \mathrm{m}$ thick CdTe $_{0.984} \mathrm{~S}_{0.016}$ layer, and a cas density of $4.8 \mathrm{~s} / \mathrm{cm}^{3}$, the $1.6 \% \mathrm{~S}$ corresponds to an equivalent cds film thickness of about $25 \mathrm{~nm}$.

The change in the CdS film properties due to the $400^{\circ} \mathrm{C}$ heat treatment depends on the thickness of the Cas layer and its

'structural' properties. Figure 39 shows the spectral response curves of three caTe/Cas devices with different cds thicknesses. For the device with $1.5 \mu \mathrm{m}$ of CaS, a moderately well defined cdS bandedge is seen at about $520 \mathrm{~nm}(2.4 \mathrm{ev})$. For the thinner cds, there is an increase in response at wavelengths below the cds bandedge as expected. However, the maximum in spectral response shifts to between 550 and $620 \mathrm{~nm}$, suggesting the formation of a lower bandgap window layer. This loss in response between 520 and $620 \mathrm{~nm}$ in cells with thin cas is not recoverable with reverse bias suggesting that the reduction is not due to recombination but to generation. The shape of the spectral response curve is consistent with diffusion of $\mathrm{Te}$ into CdS and formation of $\mathrm{a}$ $\mathrm{CdS}_{1-\mathrm{Te}} \mathrm{Te}_{\mathrm{y}}$ layer having a bandgap narrower than cds. Similar results were reported by Nakayama et al. (37) and clemminck et al. (17) for screen printed materials. Thin evaporated cas films $(<0.30 \mu \mathrm{m})$ consist mostly of small grains $(<0.1 \mu \mathrm{m})$ while thick CdS films $(>1.0 \mu \mathrm{m})$ have a columnar grain structure with grain size of $\sim 0.5 \mu \mathrm{m}$. The increased surface area due to small grains could enhance the diffusion of $\mathrm{Te}$ into the cds and the formation of a $\mathrm{CdS}_{1-\mathrm{y}} \mathrm{Te}_{\mathrm{y}}$ layer. 

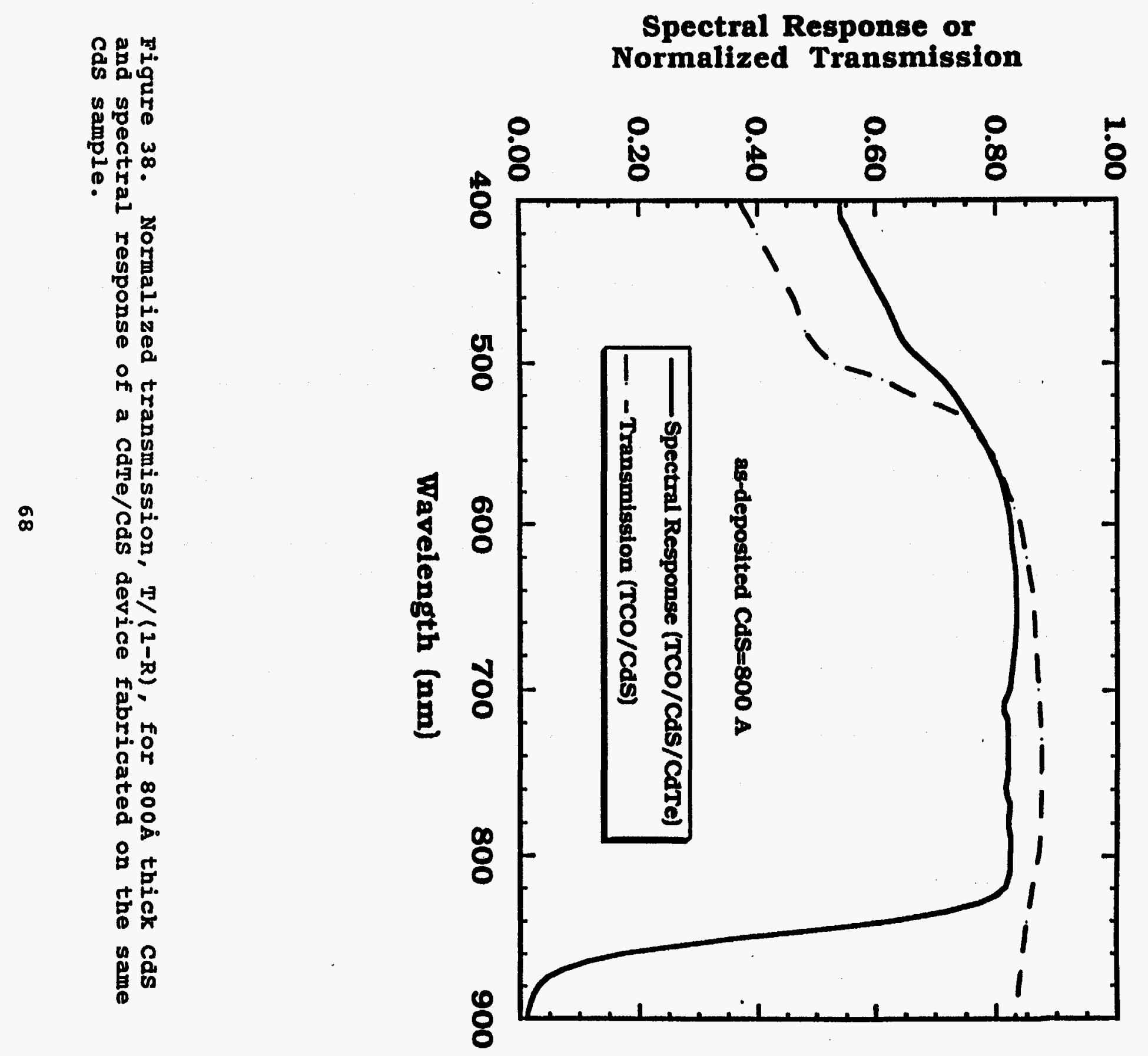


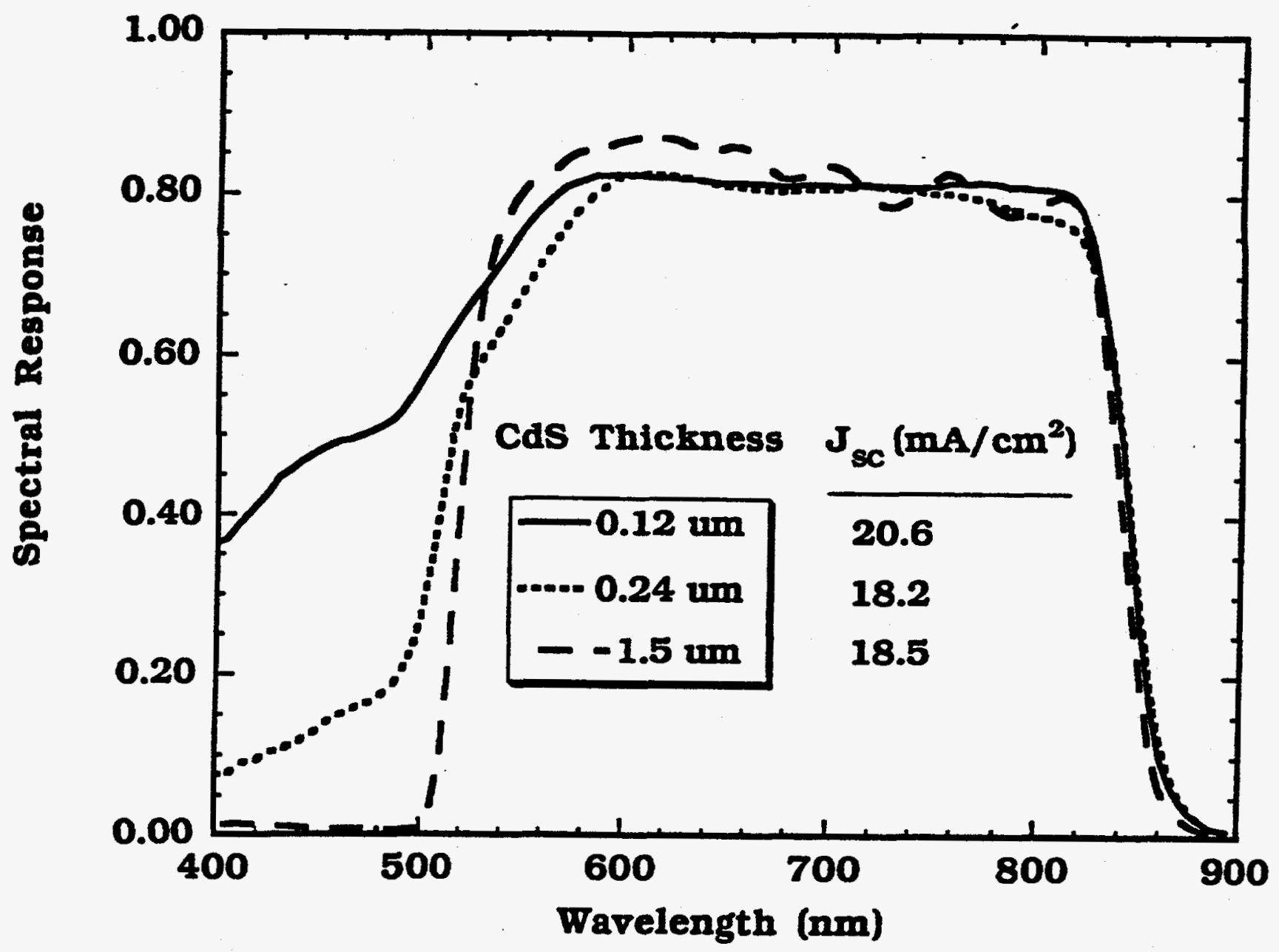

Figure 39. Comparison of spectral response of cate/cas devices with different cas thicknesses. 
Additionally, the diffusion of $\mathrm{Te}$ into thin $(0.25 \mu \mathrm{m})$ cds could be modified by post deposition heat treatment of the Cds prior to the CdTe deposition. From previous work (16), a $400^{\circ} \mathrm{C}$ air heat treatment of the cas films with from 1.5 to $8 \mu \mathrm{m}$, in the presence of $\mathrm{CdCl}_{2}$ resulted in an improved crystal structure and sharpening of the Cas optical bandedge. The effects of post deposition heat treatments of $0.24 \mu \mathrm{m}$ CdS on optical properties and subsequent device properties were evaluated for the following conditions:

1) For air heat treatments at $400^{\circ} \mathrm{C}$, the thickness of the $\mathrm{CdCl}_{2}$ layer was varied from 0.05 to $0.5 \mu \mathrm{m}$. For all samples, the $\mathrm{CdCl}_{2}$ heat treatment improved the optical bandedge as can be seen in Figure 40. However, the spectral response curves of devices fabricated using these samples, shown in Figure 41 had different shapes in the 500 to $600 \mathrm{~nm}$ indicating that the amount of interdiffusion depends on the pre-treatment of the cds and that the improvement in the optical bandedge does not correspond to shape of the spectral response curve between 500 to $600 \mathrm{~nm}$. For the $0.5 \mu \mathrm{m} \mathrm{CaCl} \mathrm{Cl}_{2}$ treatment, the shape of the spectral response curve is similar to thick Cds, see Figure 38. There is also a shift in the long wavelength response with the device made with the thickest $\mathrm{CaCl}_{2}$ layer having the smallest shift the

caTe bandedge. Thus, the $\mathrm{CdCl}_{2}$ treatment of the Cds affects both the cas and the diffusion of $S$ into caTe. Table 9 summarizes the device results for these samples. The $J_{s c}$ for all devices are essentially the same with the $V_{o c}$ and FF decreasing as the amount of $\mathrm{CdCl}_{2}$ is increased. Thus, the pre-treatment of the cas appears to affect the junction formation. 


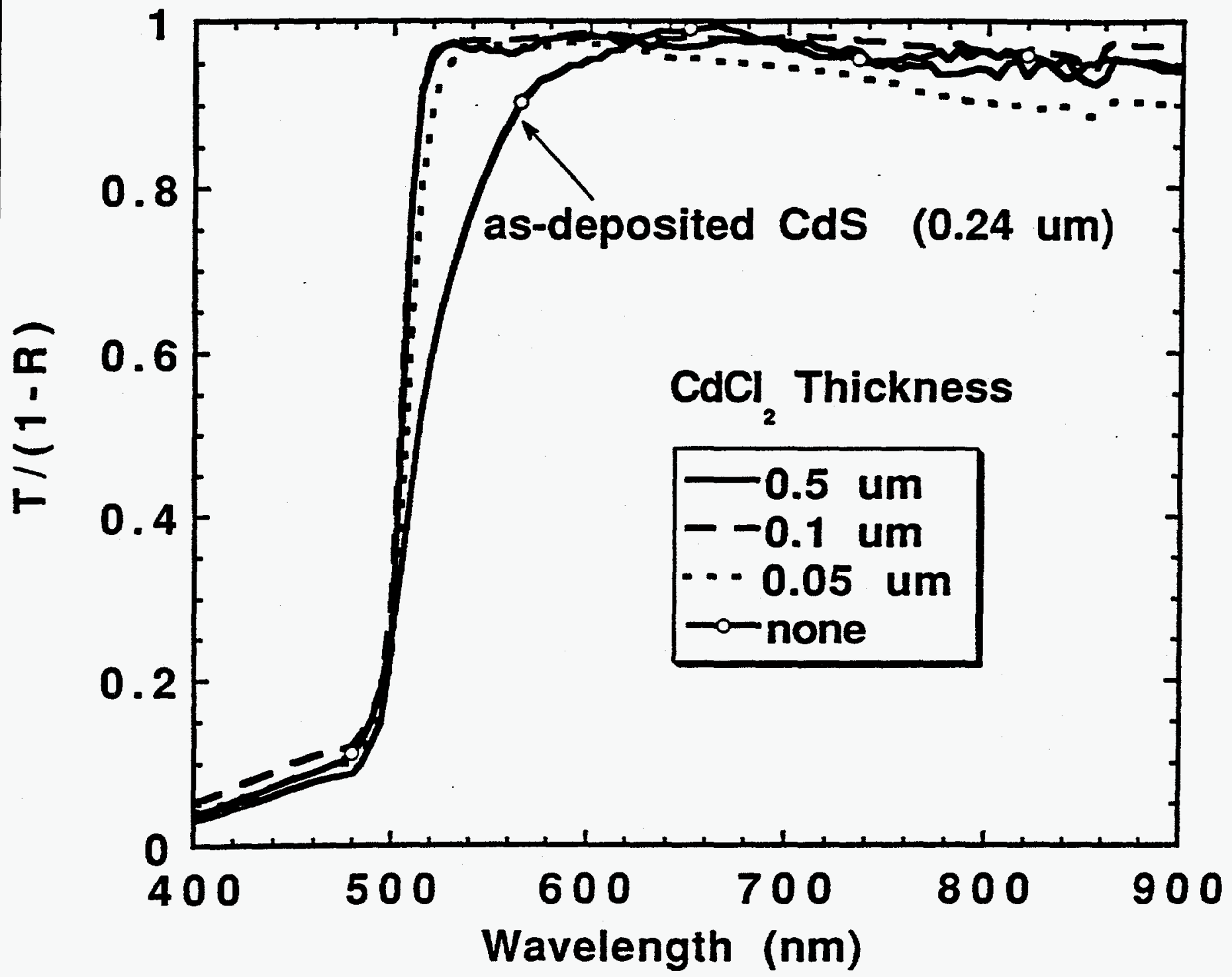

Figure 40. Normalized transmission, $T /(1-R)$, for $0.24 \mu \mathrm{m}$ thick Cas films heat treated at $400^{\circ} \mathrm{C}$ with different thicknesses of $\mathrm{CaCl}_{2}$. 


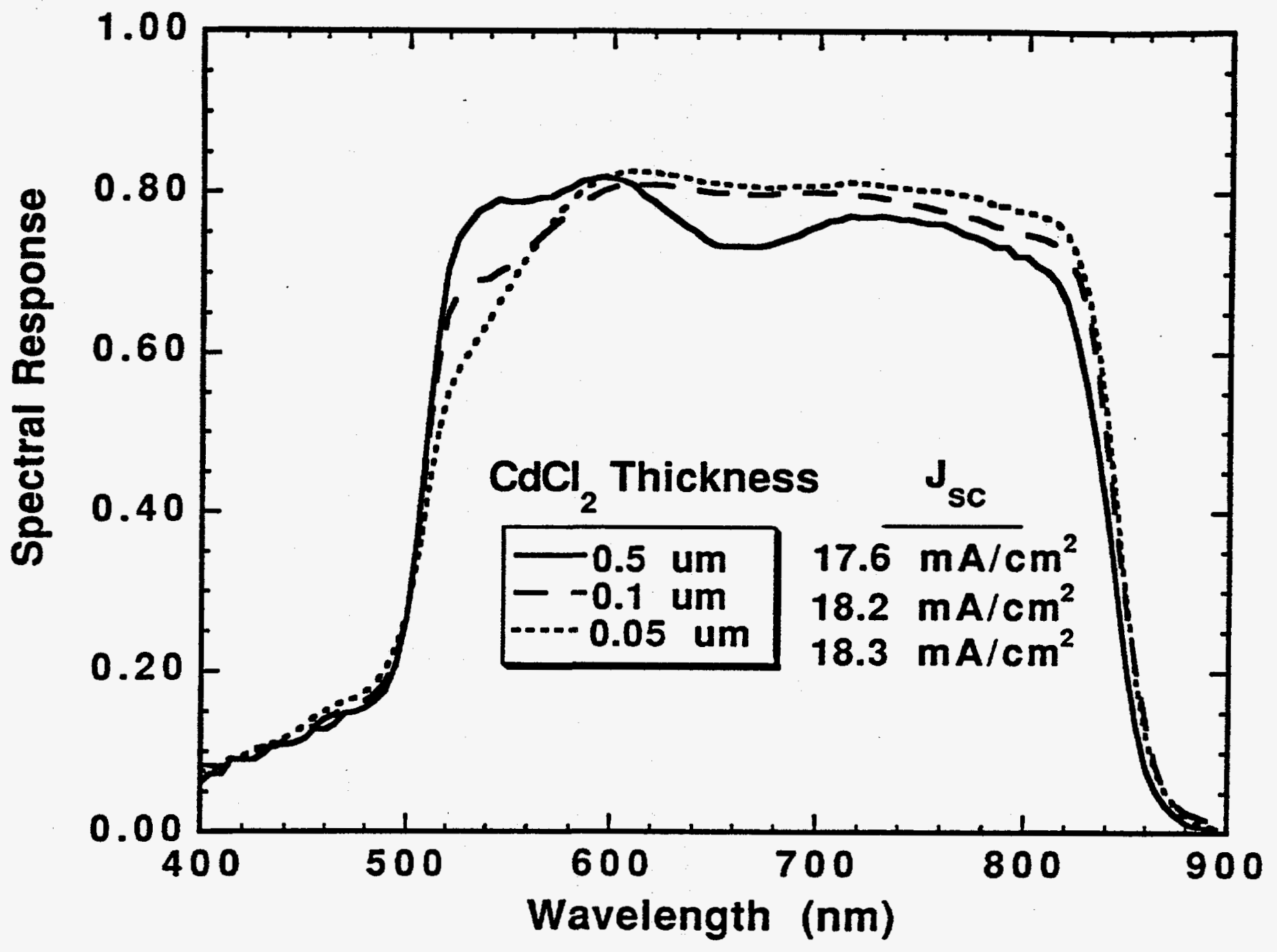

Figure 41. Spectral response of caTe/Cds devices fabricated on the cds samples of Figure 40 , having been heat treated with different thicknesses of $\mathrm{CaCl}_{2}$. 
Table 9. Effect of restructuring thin $(0.24 \mu \mathrm{m})$ cas layers with $400^{\circ} \mathrm{C} \mathrm{CaCl}_{2}$ anneal prior to caTe deposition.

$\begin{array}{llcccr}\text { Piece } & \begin{array}{l}\mathrm{CdCl}_{2} \\ \text { Thickness } \\ (\mu \mathrm{m})\end{array} & \begin{array}{l}\mathrm{V}_{\mathrm{oc}} \\ (\mathrm{V})\end{array} & \begin{array}{c}\mathrm{J}_{\mathrm{sc}} \\ \left(\mathrm{mA} / \mathrm{cm}^{2}\right)\end{array} & \begin{array}{c}\mathrm{FF} \\ (\%)\end{array} & { }^{\eta} \\ & & & & & \\ 40720-11 & 0.5 & 0.64 & 17.6 & 59 & 6.6 \\ 40721-32 & 0.1 & 0.67 & 18.2 & 61 & 7.4 \\ 40721-31 & 0.05 & 0.72 & 18.3 & 72 & 9.5 \\ 40720-31 & 0 & 0.74 & 18.1 & 66 & 8.9\end{array}$

2) For a $\mathrm{CaCl}_{2}$ thickness of $0.05 \mu \mathrm{m}$, the air heat treatment temperature was varied from 400 to $600^{\circ} \mathrm{C}$ and the times varied from 15 to $30 \mathrm{~min}$. All samples showed an improvement in the optical bandedge after heat treatment. The spectral response curves of devices made on samples treated at $400^{\circ} \mathrm{C}$ for $30 \mathrm{~min}$. and $600^{\circ} \mathrm{C}$ for 15 to $30 \mathrm{~min}$., had a moderately sharp cas bandedge while the sample treated at $400^{\circ} \mathrm{C}$ for $15 \mathrm{~min}$. similar to that shown in Figure 41 had its spectral response maximum at $\sim 600 \mathrm{~nm}$.

3) Argon, hydrogen and air heat treatments at $400^{\circ} \mathrm{C}$ without $\mathrm{CdCl}_{2} \cdot \mathrm{All}$ samples treated without $\mathrm{CdCl}_{2}$ showed an improvement in the cds optical bandedge which did not translate into device spectral response, that is there was a reduced spectral response between 500 and $600 \mathrm{~nm}$.

To summarize, heat treatment from 400 to $600^{\circ} \mathrm{C}$ of the cas after deposition improves the optical bandedge but is only correlated with the spectral response when the heat treatment includes $\mathrm{CaCl}_{2}$

The results of others, using different fabrication approaches, high and low temperature processes, for the cdTe and thin cds can be interpreted similarly. For example, Ullal et al. (38) reported the $\mathrm{J}-\mathrm{V}$ and spectral response measurements made at NREL for CdTe/CdS solar cells fabricated by a variety of techniques. Figure 42 shows the spectral response of these cells. For all devices, with the exception of GIT, the spectral response appears to peak around $600 \mathrm{~nm}$ which is consistent with the existence of a $\mathrm{CdS}_{1-y} \mathrm{Te}_{\mathrm{y}}$ layer. Additionally, there is considerable variation in the long wavelength response edge, which is indicative of varying degrees of $S$ diffusion into cdTe.

Nunoue et al. (39) presented an equilibrium phase diagram for the cdTe-cds system based on single crystal data which shows a wide miscibility gap below $760^{\circ} \mathrm{C}$. Although their results extend to only $650^{\circ} \mathrm{C}$, the miscibility gap is expected to exist at lower temperatures. In contrast, the results of ohata et al. (40), based on thin films of CdTe-Cas grown at low temperature, suggest 


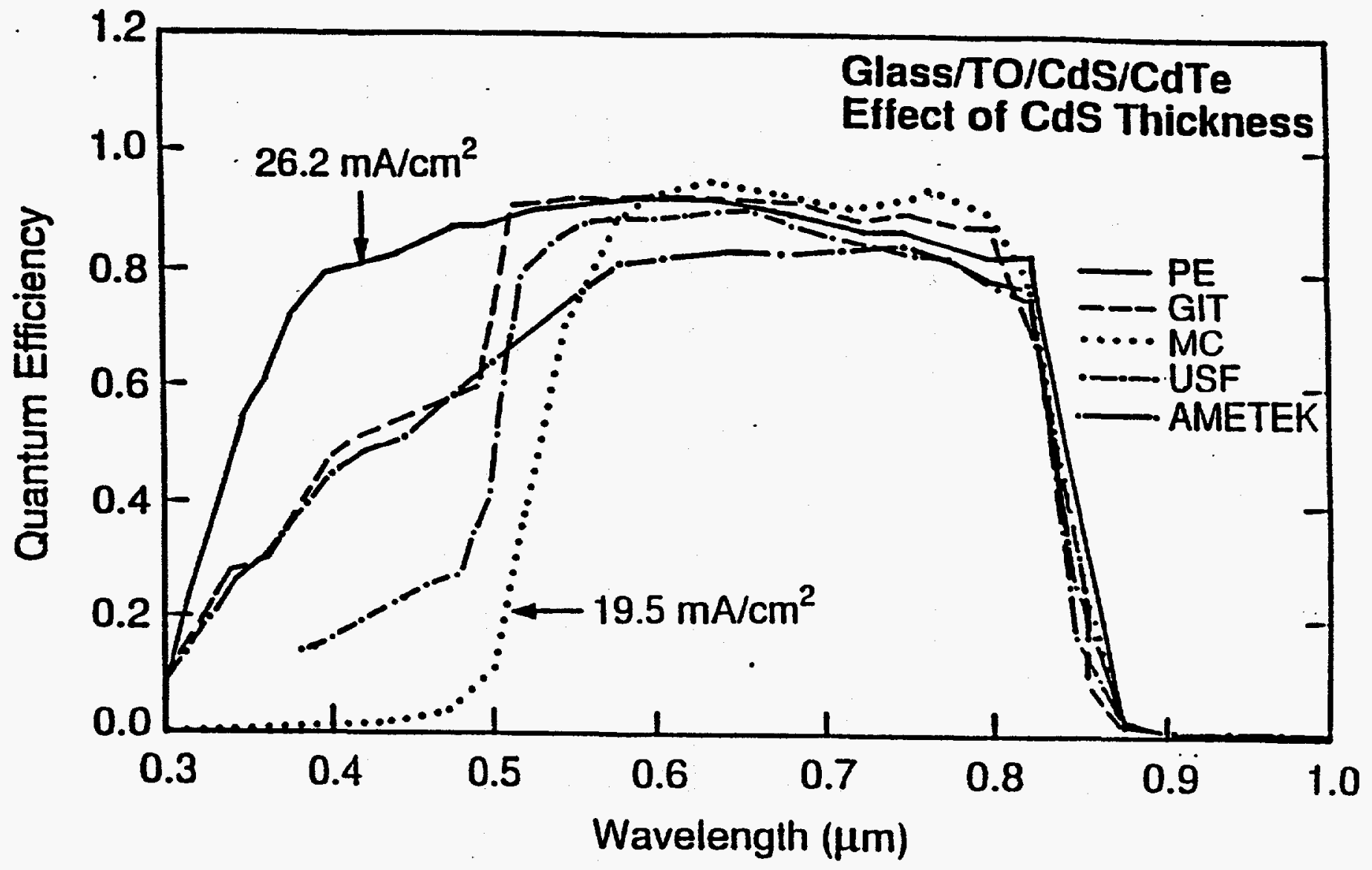

Figure 42. Quantum efficiency measurements (NREL) for CdTe/Cds solar cells fabricated by various deposition methods (from reference 7): Photon Energy, Inc. (PE) - Spray Pyrolysis; Georgia Institute of Technology (GIT) - M.O.C.V.D.; Microchemistry, ITD (MC) - A.I.E.; University of South Florida (USF) - C.S.V.T.: Ametek - Electron deposition. 
that a continuous solid solution is formed over the entire composition range which could be either a metastable or a kinetically controlled phase. These results allow a self consistent interpretation to be made of the effects of high temperature and $\mathrm{CdCl}_{2}$ processing on CdTe/Cas films:

1. For CdTe/CdS cells deposited at low temperature, initially there is a well defined cas - caTe interface.

2. The heat treatment of the caTe at $400^{\circ} \mathrm{C}$ or higher in the presence of $\mathrm{CdCl}_{2}$ results in an interdiffusion of the CdTe and CdS, which, from the phase diagram, results in the formation of discrete $\operatorname{cds}_{1-y} \mathrm{Te}_{y}$ and $\operatorname{cdTe}_{1-x} S_{x}$ layers when using thin $(0.25 \mu \mathrm{m})$ and small grain CdS. This is opposed to a continuously graded layer, which has not been observed in samples treated at high temperature.

3. The variation in short wavelength spectral response with cds thickness seems to indicate that Te diffuses slowly resulting in incomplete conversion of the CdS layer and that $\mathrm{CdCl}_{2}$ treatments of the cds inhibits the diffusion of Te into the cds. However, sulfur always diffuses into the caTe.

4. For caTe/Cds cells deposited at high temperature, there is initially a discrete cas layer and interdiffusion occurs during cdTe growth.

5. The primary effect of the interdiffusion is to reduce the spectral response between 520 and $600 \mathrm{~nm}$ and extend the spectral response to longer wavelengths. The narrowing of the cdTe bandgap necessarily implies a lower theoretical limit to $V_{\text {oc }}$.

\subsubsection{Best Efficiency Device with Evaporated CdTe/Cds Materials}

The optical losses limiting $J_{\text {sc }}$ (AMI.5 global spectrum) in our glass/ITO/CdS/CdTe devices were evaluated and the results are shown graphically in Figure 43. Increases in $J_{\text {sc }}$ of $1.5,3.0$, and $4.0 \mathrm{~mA} / \mathrm{cm}^{2}$ are possible as the cds thickness is reduced to $0.24,0.15$, and $0.08 \mu \mathrm{m}$, respectively. Reflection losses account for $2.5 \mathrm{~mA} / \mathrm{cm}^{2}$ primarily due to the specular ITO. Use of textured $\mathrm{SnO}_{2}$ substrates can reduce this 10 ss to $1.5 \mathrm{~mA} / \mathrm{cm}^{2}$; collection losses at $J_{s c}$ were typically less than $0.5 \mathrm{~mA} / \mathrm{cm}^{2}$, indicating very high quality junction and cdTe transport properties.

Based on the above, devices were fabricated using moderately thin CaS $(0.24 \mu \mathrm{m})$ on lightly textured $\mathrm{sno}_{x}$ and the results from testing these two devices at NREL are summarized in Table 10. The CdS of 40723.11 was heat treated at $400^{\circ} \mathrm{C}$ for $30 \mathrm{~min}$ with $0.05 \mu \mathrm{m} \mathrm{CaCl} 2$ while the other sample use as deposited CdS. The effect of the $\mathrm{CdCl}_{2}$ treatment on the spectral response between 


$$
\begin{aligned}
& \text { \% of total } \quad=30 \mathrm{~mA} / \mathrm{cm}^{2} \\
& \begin{array}{l}
\text { Total AM } 1.5 \mathrm{Global} \text { Current } \\
\text { below } 850 \mathrm{~nm}
\end{array}
\end{aligned}
$$

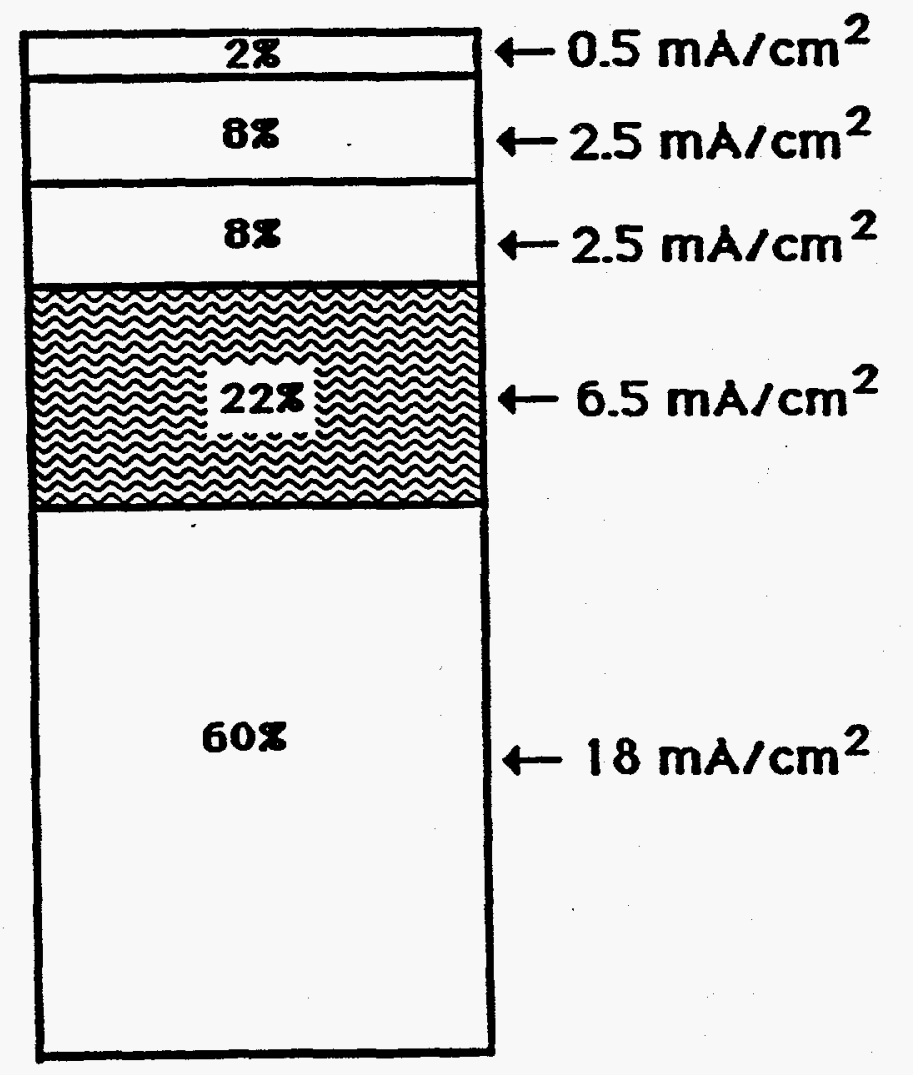

Collection losses at $J_{\text {sc }}$

Weak TCO/CdS absorption $>600 \mathrm{~nm}$

Reflection losses - specular TCO (only $1.5 \mathrm{~mA} / \mathrm{cm}^{2}$ if textured TCO)

CdS absorption below $520 \mathrm{~nm}$

Typical $J_{s c}$ for 1.5 um CdS cells (baseline)

Figure 43. Photon losses in care/cas solar cells. 
Table 10 - NREL Test Results for Cells in Figure 44

Cell

40723.11 .2

40723.12 .1
Cas Treatment

$\mathrm{CdCl}_{2}, 400^{\circ} \mathrm{C}$

none
$\mathrm{V}_{\text {oc }}$

789

799
$J_{\text {se }}$

20.1

18.4
FF

69.4

11.0

72.0

10.6

500 to $600 \mathrm{~nm}$ is shown in Figure 44 is the SR of the cells from the same cds and cdTe evaporations. The cds of one received a $0.05 \mu \mathrm{m}$ anneal prior to cdTe deposition. The device with asdeposited CdS (40723.12) shows considerable interdiffusion evidenced by the broadening of the cds edge and subsequent reduction in $J_{s c}$.

\section{2 .3 contacts}

The devices discussed above were fabricated using evaporated $\mathrm{Cu} / \mathrm{Au}$ contacts. Over the past two years, alternatives to this contact have been investigated, and a novel contacting process using $\mathrm{ZnTe}$ was developed under a separate NREL subcontract \#ZM-018110-1. Alternatives to $\mathrm{Cu} / \mathrm{Au}$ were evaporated $\mathrm{Cu} / \mathrm{Mo}$ and $\mathrm{Cu} / \mathrm{Pt}$, and galvanically deposited Cu-doped $\mathrm{ZnTe}$ plus a robust metal layer. In the case of $\mathrm{Cu} / \mathrm{Au}, \mathrm{Cu} / \mathrm{Mo}$, and $\mathrm{Cu} / \mathrm{Pt}$ the CdTe surface was not etched prior to contacting, and cell optimization consisted of a $150^{\circ} \mathrm{C}$ air heat treatment followed by immersion in $\mathrm{Br}_{2} \mathrm{CH}_{3} \mathrm{OH}$. For devices with $\mathrm{ZnTe}: \mathrm{Cu}$ contacts, the caTe surface was etched in $\mathrm{Br}_{2} \mathrm{CH}_{3} \mathrm{OH}$ prior to $\mathrm{ZnTe}$ deposition and cell optimization consisted only of an air heat treatment at $150^{\circ} \mathrm{C}$. Promising J-V results were obtained for the alternative contacts as shown in Table 11 for ITO/CdS/CdTe cells. In most cases, the devices with alternative contacts to $\mathrm{Cu} / \mathrm{Au}$ had crossover between light and dark $\mathrm{J}-\mathrm{V}$ curves and slightly higher slope at $\mathrm{V}_{\text {oc }}$ $(\mathrm{dV} / \mathrm{dJ})$ on the light curve. These differences are likely due to non-optimal processing conditions for the alternative materials such as thickness and optimization temperature, time, and atmosphere.

Also, the difference in performance between devices with different contacts is that the optimization steps used do not necessarily result in an "end-point" condition for the device, which is manifest at later dates by a change in the device $\mathrm{J}-\mathrm{V}$ curve and device parameters. 


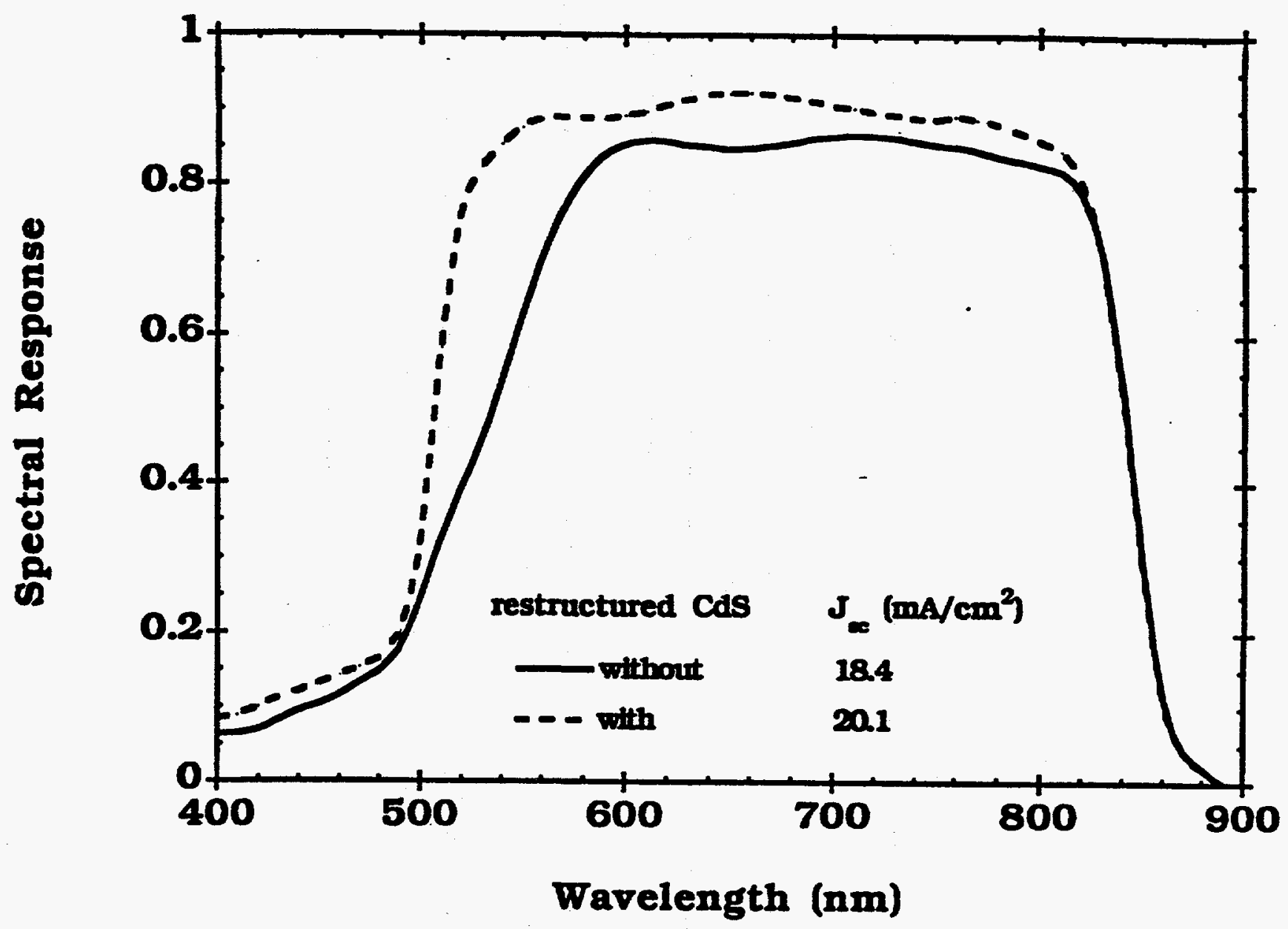

Figure 44. Spectral response of high efficiency caTe/Cas cells using evaporated caTe and cas layers. Sample 40723.11 used cas which was heat treated at $400^{\circ} \mathrm{C}$ with $\mathrm{CdCl}_{2}$ prior to CdTe deposition. 
Table 11. J-V device parameters for ITO/CdS/CdTe cells with different contacts. Measurements made under ELH illumination, normalized to $100 \mathrm{~mW} / \mathrm{cm}^{2}$ e $32^{\circ} \mathrm{C}$.

\begin{tabular}{|c|c|c|c|c|c|}
\hline Device \# & Contact & $\begin{array}{l}V_{o c} \\
(\mathrm{mV})\end{array}$ & $\begin{array}{l}\mathrm{J}_{\mathrm{sc}} \\
\left(\mathrm{mA} / \mathrm{cm}^{2}\right)\end{array}$ & $\begin{array}{l}F F \\
(z)\end{array}$ & $\begin{array}{l}\mathrm{dV} / \mathrm{dJ} \\
\text { @ } \mathrm{V}_{\mathrm{oc}} \\
\mathrm{ohm}-\mathrm{cm}^{2}\end{array}$ \\
\hline $\begin{array}{l}40689.12-5 \\
40688.232-1 \\
40682.122-2 \\
40690.221-1 \\
40691.231-2 \\
40690.232-2 \\
40691.13-2 \\
40694.23-1\end{array}$ & $\begin{array}{l}100 \AA \mathrm{Cu} / 500 \AA \mathrm{Au} \\
100 \AA \mathrm{Cu} / 1500 \AA \mathrm{Mo} \\
100 \AA \mathrm{Cu} / 500 \AA \mathrm{At} \\
500 \AA \mathrm{ZnTe}: \mathrm{Cu} / \mathrm{Ni} \\
500 \AA \mathrm{ZnTe}: \mathrm{Cu} / \mathrm{Cu} / \mathrm{Au} \\
500 \AA \mathrm{ZnTe}: \mathrm{Cu} / \mathrm{Cu} / \mathrm{Au} \\
500 \AA \mathrm{ZnTe}: \mathrm{Cu} / \mathrm{ITO} / \mathrm{Ni} \\
500 \AA \mathrm{ZnTe}: \mathrm{Cu} / \mathrm{ITO} / \mathrm{Ni}\end{array}$ & $\begin{array}{l}782 \\
683 \\
660 \\
616 \\
703 \\
754 \\
709 \\
766\end{array}$ & $\begin{array}{l}17.3 \\
17.4 \\
18.0 \\
15.2 \\
16.8 \\
17.4 \\
16.3 \\
17.9\end{array}$ & $\begin{array}{l}73.5 \\
61.9 \\
63.2 \\
74.8 \\
69.0 \\
60.5 \\
68.3 \\
54.6\end{array}$ & $\begin{array}{r}4.3 \\
5.9 \\
4.3 \\
4.0 \\
3.9 \\
7.6 \\
5.3 \\
11.2\end{array}$ \\
\hline
\end{tabular}

\subsubsection{Stability of CdTe Devices}

Because some of the cdTe devices made have shown changes in current-voltage behavior over time, IEC has been regularly retesting some of the higher efficiency solar cells made. Between current voltage tests, the devices have been stored in ordinary cabinets or desiccators. So far 678 solar cells from 52 different samples have been subject to a number of retests over periods ranging from 100 to over 1000 days. Among the samples are: one made at Ametek; one made with Ametek cdTe and contacted with $\mathrm{Cu} / \mathrm{Au}$ at IEC; one made with IEC CdTe and contacted with ZnTe at Ametek; and 48 made at IEC. The 48 samples made completely at IEC have the following back contacts; one $\mathrm{Cu} / \mathrm{Pt}$, two $\mathrm{Cu} / \mathrm{Mo}$, eight with a ZnTe layer, and 37 with $\mathrm{Cu} / \mathrm{Au}$. A brief summary of the parameters measured during the current voltage tests of thirteen of the samples which have been retested over periods greater than 300 days or, which represent one of the unusual contacts is shown in Appendix B.

As can be seen in Appendix B, most of the devices change in output over time. Although most of the cells decrease in efficiency, some do increase. Because on the same sample, where each cell has been processed together, some cells increase in efficiency while others decrease (compare cells 5 and 6 on sample 40689-12 for example); it is not possible to ascribe the changes to any specific part of the device processing. But, most of the change in the output occurs because of a change in fill factor. When examined more closely, the change in fill factor is caused by a change in effective series resistance, as is shown by the slope of the current voltage curve at $v_{o c}$ (i.e. (dV/dJ) $V=v_{o c}$ ). 
To summarize, solar cells that have been tested over periods ranging in time from three months to nearly three years have been found to change in efficiency (both up and down). This change is associated with a change in the effective series resistance. We would expect this type of change to be associated with the contacting. However, the changes do not necessarily correlate with cells on the same sample which should have had the same processing. It is suspected that the preparation or treatment of the caTe surface prior to contacting is involved in these changes. Further work along these lines is continuing.

\section{2 .5 Future Work}

Fabrication and analysis of cdTe/Cas cells using evaporated cdTe layers has led to $11 \%$ efficient cells and to an improved understanding of the role of processing steps on device structure and performance. The performance of these cells is limited by $\mathrm{J}_{\mathrm{sc}} \sim 20 \mathrm{~mA} / \mathrm{cm}^{2}$ and $\mathrm{V}_{\text {oc }} \sim 800 \mathrm{mV}$. We will increase $\mathrm{J}_{\text {sc }}$ by further reducing the cas thickness, using solution growth techniques, and by optimizing the post deposition process for thinner cds.

The influence of cdTe-cds interdiffusion during post processing heat treatments on device behavior will be investigated. In particular, the extent of interdiffusion will be quantified and the relationship between the finished device structure to existing cdTe-cds phase diagrams will be established.

The operating model for $V_{o c}$ in these devices is based on grain boundary geometry and electronic properties. Alternative chemical and thermal reactions will be investigated at the recrystallization step in the processing. We will quantify the extent of cdTe grain restructuring (size and orientation) due to different treatment conditions.

The interrelationship between the post deposition processing treatments, the caTe surface after treatment, the contact to cdTe, and device performance and stability will be further investigated. 


\section{REFERENCES}

K. Zweibel, H.S. Ullal, R.L. Mitcheli, and R. Noufi, Proc. 22nd IEEE PVSC, Las Vegas, NV, 1057 (1991). B.N. Baron, R.W. Birkmire, J.E. Phillips, W.N. Shafarman, S.S. Hegedus, and B.E. McCandless, Annual Report under SERI Subcontract No. XN-0-10023-1 for the period 1/16/90 to $1 / 15 / 91$ (March 1991).

T.I. Chu, S.S. Chu, J. Britt, C. Ferekides, C. Wang, and C.Q. Wu, IEEE Elect. Dev. Letters 13, \#5, 303 (1992). K.W. Mitchell, C. Eberspacher, J. Ermer and D. Pier, Proc. 20th IEEE Photov. Spec. Conf., 1384 (1988). W.E. Devaney, W.S. Chen, J.M. Stewart and R.A. Mickelsen, IEEE Trans. Elect. Devices, 37, \#21, 428 (1990).

T. Walter, R. Menner, M. Ruckh, L. Käser and H.W. Schock, Proc. 22nd IEEE Photov. Spec. Conf., 924 (1991). A.L. Fahrenbruch and R.H. Bube, Fundamentals of solar Cells (Academic Press, N.Y., 1983), p. 312.

Ibid p. 408. Ibid p. 131 . A. Rose and E.D. Johnson, Proc. IRE 47, 407 (1959). K.W. Mitchell and H.I. Liu, Proc. 20th IEEE Photov. Spec. Conf., 1461 (1988).

M. Roy, S. Damaskinos, and J.E. Phillips, Proc. 20th IEEE Photov. Spec. Conf., 1618 (1988).

M. Roy, Ph.D. Thesis, Univ. of Del., Newark, DE (1989). W.N. Shafarman and J.E. Phillips, Proc. 22nd IEEE Photov. Spec. Conf., 934 (1991). D.A. Fardig and J.E. Phillips, Proc. 22nd IEEE Photov. Spec. Conf., 1146 (1991). B.E. McCandless and S.S. Hegedus, Proc. 22nd IEEE Photov. Spec. Conf., 967 (1991). I. Clemminck, M. Burgelman, M. Casteleyn, J. DePoorter and A. Vervaet, Proc. 22nd IEEE Photov. Spec. Conf., 1114 (1991).

G.B. Turner, R.J. Schwartz and J.L. Gray, Proc. 20th IEEE Photov. Spec. Conf., 1457 (1988). Y.J. Lee and J.L. Gray, Proc. 22nd IEEE Photov. Spec. Conf., 1151 (1991).

A. Fahrenbruch and R. Bube, "Fundamentals of Solar Cells", (Academic Press, NY, 1983), p. 163.

J.B. Yoo, A. Fahrenbruch, and R. Bube, J. Appl. Phys. 68,4694 (1990).

M. Roy and J. Phillips 2lst IEEE PVSC, 743 (1990). G.A. Pollock, K.W. Mitchell, and J.H. Ermer, European Patent Application, \#89308108.3, Aug. 9, 1989. B.E. McCandless and R.W. Birkmire, Solar Cells 31, 527 (1991). 
N. Suyama, T. Arita, Y. Nishiyama, N. Veno, S. Kitamura, and M. Murozono, Proc. 21st IEEE PVSC, 498 (1990). P.V. Meyers, Solar Cells 23, 59 (1988). A. Mondal, B.E. McCandless, R.W. Birkmire, Proc. 22nd IEEE PVSC, 1126 (1991). J.P. Ponpon, Solid State Electronics, $28(7), 689$ (1985). J.E. Phillips, M. RoY, Proc. 20th IEEE PVSC, 1614 (1988) . J.E. Phillips, Proc. 21st IEEE PVSC, 782 (1990).

D.W. Hoffman, J. Vac. Sci. Technol. $20(3), 355$ (1982).

B.M. Basol, V.K. Kapur and R.J. Matson, Proc. 22nd IEEE PVSC, Las Vegas, NV, 1179 (1991).

K.C. Mills, Thermodynamic Data for Inorganic Sulphides, Selenides and Tellurides, Butterworth (1974). Vertag (1988). R.K. Pearson and G.R. Haugen, Int. J. of Hydrogen Energy, 6(5), 509 (1981). S.A. Ringel, A.W. Smith, M.H. MacDougal, and A. Rohatgi, J. Appl. Phys. 70 (2), 881 (1991).

K. Ohata, J. Saraie, and T. Tanaka, Jap. J. Appl. Phys. $12(10), 1641$ (1973).

N. Nakayama, H. Matsumoto, A. Nakano, S. Ikegami, H. Uda, T. Yamashita, Jap. J. Appl. Phys. 19, 703 (1980). H. Ullal, J. Stone, K. Zweibel, T. Surek, R. Mitchell, 6 th Int' 1 PVSEC, New Delhi, 81 (1992). S. Nunoue, T. Hemmi, E. Kato, J. Electrochem. Soc. 137, 1248 (1990). J. Saraie, H. Kato, N. Yamada, Sh. Kaida, and T. Tanaka, Phys. Stat. Sol. (a) 39, 331 (1977). 


\section{ABSTRACT}

Results and conclusions of Phase II of a multi-year research program on polycrystalline thin film heterojunction solar cells are presented. The research consisted of the investigation of the relationships between processing, materials properties and device performance. This relationship was quantified by device modeling and analysis. The analysis of thin film polycrystalline heterojunction solar cells explains how minority carrier recombination at the metallurgical interface and at grain boundaries can be greatly reduced by the proper doping of the window and absorber layers. When this is done, these devices exhibit the high quantum efficiencies and $J_{s c}$ 's measured in high efficiency caTe and CuInse, based solar cells. The analysis also shows that any quantitative modeling of these devices which related the device performance to the bulk electronic properties of the material must consider the additional geometric dimension introduced by the polycrystallinity. Additional analysis and measurements show that the present solar cells are limited by the magnitude of the diode current which appears to be caused by recombination in the space charge region.

Analysis of the $J-V$ characteristics of CuInse $/(C d z n) S$ cells have been used to examine the role of different current mechanisms in the device. No evidence was found for interface recombination or other mechanisms, although interface recombination is expected to limit $\mathrm{V}_{o c}$ to $\sim 0.52 \mathrm{~V}$. The light intensity dependence was also examined and it is shown that the diode quality factor (A), reverse saturation current density $\left(J_{0}\right)$, and shunt conductance (G) all vary with the intensity. Finally, ways to improve $v_{\text {oc }}$ are discussed.

Current-voltage and spectral response measurements have also been made on high efficiency cdTe/CdS thin film solar cells prepared by vacuum evaporation. Analysis of the measurements indicate that these solar cells operate as $p-n$ heterojunctions and the current transport in the junction region is dominated by Shockley-Read-Hall recombination in the CdTe. The analysis also indicates that the light generated current varies with the applied voltage.

$\mathrm{Cu}-$ In bilayers were reacted with both elemental $\mathrm{Se}$ and $\mathrm{H}_{2} \mathrm{Se}$ gas

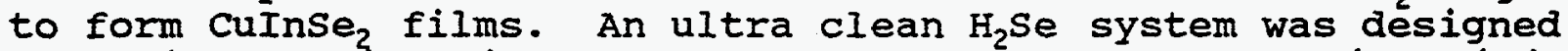
and built and is being used to evaluate the effect of impurities on the selenization reaction. Thermodynamic calculations for the dissociation of $\mathrm{H}_{2} \mathrm{Se}$ were performed and a kinetic model developed based on pyrolysis experiments and literature data.

The reaction pathways and the precursors to formation of $\mathrm{CuInSe}_{2}$ using $\mathrm{Se}$ and $\mathrm{H}_{2} \mathrm{Se}$ were evaluated and compared. The growth of 
CuInse $_{2}$ using either $\mathrm{H}_{2} \mathrm{Se}$ or $\mathrm{Se}$ vapor proceeds through the formation of a $\mathrm{Cu}_{11} \mathrm{In}_{9}$ alloy and indium selenide phases ( $\mathrm{In} \mathrm{n}_{2} \mathrm{Se}$ and Inse). The only different precursor in the two reacting systems is the formation of a copper selenide phase observed only when using se vapor. The reaction with se vapor proceeds faster than the selenization of a copper-indium bilayer in the tubular reactor with $\mathrm{H}_{2} \mathrm{Se}$ at a temperature $\mathrm{T}$ are observed in the evaporator (using $\mathrm{Se}$ vapor) at a temperature $\mathrm{T}-50^{\circ} \mathrm{C}$.

Additionally, several approaches to fabricating cuInse thin film $_{2}$ solar cells in a superstrate configuration have been explored. The CuInse, films were grown on glass/TCo/Cds substrates by both 3-source elemental evaporation and selenization.

By analyzing cdTe/CdS devices fabricated by vacuum evaporation, a self consistent picture of the effects of processing on the evolution of caTe cells was developed which can be applied to other fabrication methods. In fabricating caTe/cds solar cells by evaporation, a $400^{\circ} \mathrm{C} \mathrm{CaCl}_{2}$ heat treatment is used which recrystallizes the CdTe and interdiffuses the cds and cdTe layers. The interdiffusion can change the bandgap of both the cdTe and CdS which modifies the spectral response of the solar cell. After this heat treatment a contacting/doping procedure is used which converts the cdTe conductivity to p-type by diffusion of $\mathrm{Cu}$ from the contact. Finally, the cell is treated with $\mathrm{Br}_{2} \mathrm{CH}_{3} \mathrm{OH}$ which improves both $\mathrm{V}_{o c}$ and $\mathrm{FF}$. Analogous process steps are used in most fabrication processes for CdTe/Cds solar cells. 
Appendix A

"Critical Progress Issues in Selenization"

S. Verma, R.D. Varrin, Jr., R.W. Birkmire and TWF Russell 


\title{
Presented at the 22nd IEEE Photovoltaic Specialists Conference \\ Las Vegas, Hevada October 7-11, 1991
}

\author{
GRIIICAL PROCESS ISSUES IN SELENIZATION
}

S. Verma, R.-D. Varrin, Jr., R. W. Birkmire, and TWF Russell

\author{
Institure of Energy Conversion \\ University of Delaware \\ Newark, Delaware $19716 \cdot 3820$
}

\begin{abstract}
Both $\mathrm{H}_{2} \mathrm{Se}$ and elemental selenium are used to form copper indium diselenide. Equilibrium thermodynamic calculations for $\mathrm{H}_{2} \mathrm{Se}$ dissociation show that the higher order $\mathrm{Se}_{\mathrm{x}}$ species ( $\mathrm{Se}_{\mathrm{g}}$, $\mathrm{Se}_{6}, \mathrm{Se}_{7}$ ) are important at temperatures below $800^{\circ} \mathrm{K}$ whereas $\mathrm{Se}_{2}$ becomes the predominant species at temperatures above $900^{\circ} \mathrm{K}$. A kinetic model is presented for the decomposition of $\mathrm{H}_{2} \mathrm{Se}$. The reaction is found to be first order at short times, but the reverse reaction of $\mathrm{Se}_{\mathrm{x}}$ with $\mathrm{H}_{2}$ assumes importance at higher conversions and longer times. The constants in the kinetic model are calculated from the data available in literature ${ }^{4}$ and our experiments.
\end{abstract}

\section{INTRODUCTION}

The formation of CuInSe, thin films by selenization has been accomplished in a variety of reaction systems including closed ampoules, open reaction tubes, and furnace reactors. Previously, we reported on the development of a closed reaction system (Fig. 1) where either $\mathrm{Se}$ or $\mathrm{H}_{2} \mathrm{Se}$ is transported via thermosiphon. ${ }^{1}$ In the design of this system, we identified critical areas requiring aditional experimental data. In particular, the reaction chemistry leading to the formation of $\mathrm{CuInSe}_{2}$ films had not been well characterized. Furcher. when using $\mathrm{H}_{2} \mathrm{Se}$, the gas phase species and relative concentrations due to $\mathrm{H}_{2} \mathrm{Se}$ pyrolysis were not identified. In this paper. we present thermodynamic and kinetic data on the decomposition of $\mathrm{H}_{2} \mathrm{Se}$. This daca is usetul in evaluating CuInSe, film growth and in the design of efficient commercial scale reactors.

$\mathrm{H}_{2} \mathrm{Se}$ is a colorless. extremeiy toxic gas which has received wide actention as a selenium source in the formation of $\mathrm{CuInSe}_{2}$ thin films. The decomposition products of $\mathrm{H}_{2} \mathrm{Se}$ have been idencified as polymeric Se species. ${ }^{2} .2$ If $\mathrm{H}_{2} \mathrm{Se}$ is used for selenization, both $\mathrm{H}_{2} \mathrm{Se}$ and the product selenium species could be available for reaction with the copper/indium layer to form $\mathrm{CuInSe}_{2}$. The general consensus in the literacure dealing with the thermolysis or pyrolysis of hydrogen selenide is that the following overail reaction roverns its decomposition.

$$
\mathrm{H}_{2} \mathrm{Se} \leftrightarrow \mathrm{H}_{:}+1 / 2 \mathrm{Se}_{2} \text { ? }
$$

The reaction is endothermic with an enthalpy change $\Delta H^{\circ}{ }_{29 a}$ of $9.7 \mathrm{kcal} / \mathrm{mole}$ and a free energy change $\Delta G^{\circ}{ }_{298}$ of $14.46 \mathrm{kcal} / \mathrm{mole}{ }^{3}$ Only a IImited amount of research on the reaction order and race constants for this reaction has been performed."

\section{Thermodynamics of $\mathrm{H}_{2} \mathrm{Se}$ Dissociation}

Whereas the stoichiometry and structure of gas phase Se species in equilibrium with molten selenium has been measured by mass spectroscopy techniques, ${ }^{2}$ the products of the decomposition of hydrogen selenide have not been measured. The dissociation of $\mathrm{H}_{2} \mathrm{Se}$ may be considered as occurring by the following series of independent chemical reactions.

$$
\mathrm{xH}_{2} \mathrm{Se}(\mathrm{g}) \longleftrightarrow \mathrm{xH}_{2}(\mathrm{~g})+\mathrm{Se}_{x}(\mathrm{~g})
$$

where $x$ is $1,2,3,5,6$, and 7 .

Tabulated free energies of formation' are used to calculate the decomposition of $\mathrm{H}_{2} \mathrm{Se}$ at equilibrium. The equilibrium constant $K_{y}$ is related to the Gibbs free energy change of the reaction by:

$$
k_{y}-\frac{y_{H_{2}}{ }^{x} y_{S e}}{y_{H_{2} S e}}=\exp \left(-\Delta G_{r m} x, R T\right)
$$

where:

$$
y \text { - gas phase mole fraction. }
$$

Equation 2 assumes ideal gas behavior at the temperatures and pressures of interest and at a cotal pressure of 1 acmosphere. If we select as a basis 1 mole of molissociared $\|_{7} 5 r$. then $n$ umber of noles will react in the $x^{i h}$ reaction. We can set up the equilibrium relations based on equation 2 for each of the chemical equations.

$$
\begin{aligned}
& \text { It is helpful to define: } \\
& n_{2}=E x n_{x} \\
& n_{H_{2}} \text { Se }-L-E x n_{x}
\end{aligned}
$$




$$
n_{t}-1+\sum n_{x}
$$

where, $x-1,2,3,5,6,7$;

e. 8 .

$$
y_{H_{2} S e}-\frac{n_{H_{2} S e}}{n_{t}}
$$

The general relationship is:

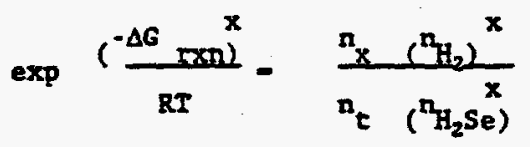

The Gibbs free energy change for each reaction is calculated from the elemental Gibbs free energy and the enthalpy of formation data tabulated in K.C. MIIIs. ${ }^{2}$ The six non-Iinear equations are numerically solved at temperatures from $300^{\circ}$ to $1400^{\circ} \mathrm{K}$. The resultant fraction of $\mathrm{H}_{2} \mathrm{Se}$ dissociated is plotted as a function of temperature in Figure 2 for:

- $\mathrm{Se}_{2}$ as the sole selenium species;

- $\mathrm{Se}_{2}, \mathrm{Se}_{3}$ and $\mathrm{Se}_{6}$ as product selenium species:

- $\mathrm{Se}_{2}, \mathrm{Se}_{5}, \mathrm{Se}_{6}, \mathrm{Se}_{7}$ as the product selenium species:

- $\mathrm{Se}_{2}, \mathrm{Se}_{3}, \mathrm{Se}_{5}, \mathrm{Se}_{6}, \mathrm{Se}_{7}$ as the product selenium species.

Our data and that of Pearson is shown on the plot as well as some much older data from Flogel and Preuner. ${ }^{3}$ Over the range of typical selenization temperatures $\left(600^{\circ} \mathrm{K}-800^{\circ} \mathrm{K}\right)$, there is satisfactory agreement with experimental data.

The the rmodynamics of $\mathrm{H}_{2} \mathrm{Se}$ dissociation suggests that $80 \mathrm{z}$ of the $\mathrm{H}_{2} \mathrm{Se}$ species decomposes to primarily $\mathrm{Se}_{7}, \mathrm{Se}_{6}$ and $\mathrm{Se}_{5}$ around $300^{\circ} \mathrm{K}$. Se becomes increasingly important at temperatures above $800^{\circ} \mathrm{K}$ and is the dominant species present at remperatures above $950^{\circ} \mathrm{K}$. Analysis of the data at $700^{\circ} \mathrm{K}$ suggests that $\mathrm{Se}_{2}$ and $\mathrm{Se}_{6}$ are the dominant species.

The the rmodynamic analysis does not give any information as to the rate of dissociation of $\mathrm{H}_{2} \mathrm{Se}$. In the next section, we present a model to consider this issue.

\section{Kinetics of $\mathrm{H}_{2} \mathrm{Se}$ Dissociation}

We have performed pyrolysis experiments in the cemperature range $673^{\circ} \mathrm{K}-723^{\circ} \mathrm{K}$ using the apparatus drawn in figure $3 .^{5}$ The experimental procedure was similar to that used by Pearson." In a typical experiment the system was pumped

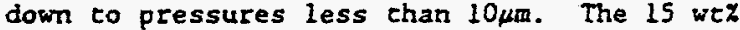
$\mathrm{H}_{2} \mathrm{Se}$ mix was admitted to the vacuum manifold through a mass flow concroller to a pressure of about 700 torr. The valves to the preheated pyrolysis bulb were then opened for about $5 \mathrm{sec}$. and the amount of $\mathrm{H}_{2} \mathrm{Se}$ charged was obtained from the difference in pressure measurements. The $\mathrm{H}_{2} \mathrm{Se}$ remaining in the vacuum manifold was pumped out. The reaction time was started when the $\mathrm{H}_{2} \mathrm{Se}$ was charged to the pyrolysis bulb and stopped when the gas was released through the traps. The $\mathrm{H}_{2} \mathrm{Se}$ and its dissoclation products are pumped through the two traps. $\mathrm{H}_{2} \mathrm{Se}$ and the selenium species are condensed in IIquid $\mathrm{N}_{2}$ traps. Argon and $\mathrm{H}_{2}$ are removed from the system by pumping. The pyrolysis system was then isolated and the cold traps were dropped. The pressure of unreacted $\mathrm{H}_{2} \mathrm{Se}$ trapped in the cold traps was measured after about five minutes to allow the $\mathrm{H}_{2} \mathrm{Se}$ to evaporate. The primary difference between our experiments and Pearson's was that Pearson used triple distilled vacuum outgassed $\mathrm{H}_{2} \mathrm{Se}$ where as we used the 15 wtz $\mathrm{H}_{2} \mathrm{Se}$ in Argon gas as received from the manufacturer.

Since we (or Pearson) could not measure concentrations of $\mathrm{Se}_{x}$ species as a function of time, we based our analysis on the following chemical equations:

$$
\begin{aligned}
& \mathrm{H}_{2} \mathrm{Se} \longleftrightarrow \mathrm{H}_{2}+1 / 2 \mathrm{Se}_{2} \\
& \mathrm{H}_{2} \mathrm{Se} \longleftrightarrow \mathrm{H}_{2}+1 / 6 \mathrm{Se}_{6}
\end{aligned}
$$

The thermodynamic analysis predicts the importance of both these species in the temperature ranges examined in the pyrolysis experiments.

Applying the law of conservation of mass to the batch pyrolysis reactor and assuming the simplest possible form for the rate expressions yields:

$$
\begin{aligned}
& d C_{\mathrm{H}_{2} \mathrm{Se}} / \mathrm{dt}-\mathrm{k}_{\mathrm{f}} \mathrm{C}_{\mathrm{H}_{2} \mathrm{Se}}-\mathrm{k}_{\mathrm{f}} \mathrm{C}_{\mathrm{H}_{2}} \mathrm{C}_{\mathrm{Se}_{2}}^{1 / 2} \\
& d C_{\mathrm{H}_{2} \mathrm{Se}} / \mathrm{dt}-\mathrm{k}_{\mathrm{f}} \mathrm{C}_{\mathrm{H}_{2} \mathrm{Se}}-\mathrm{k}_{\mathrm{f}} \mathrm{C}_{\mathrm{H}_{2}} \mathrm{C}_{\mathrm{Se}_{6}}^{1 / 6}
\end{aligned}
$$

At short times, the reverse reaction terms will be small so the rate of change of $\mathrm{H}_{2} \mathrm{Se}$ conversion may be assumed to be first order in the $\mathrm{H}_{2} \mathrm{Se}$ conversion.

$$
d C_{H_{2} S e} / d t=-k_{E} C_{H_{2}} \mathrm{Se}
$$

Integrating (11) gives:

$$
\ln \frac{\mathrm{C}_{\mathrm{H}_{2} \mathrm{Se}(t)}}{\mathrm{C}_{\mathrm{H}_{2} \mathrm{Se}(t-0)}}=-k_{f} t
$$

Figure 4 presents the short eime best fit to the above functional form for $\mathrm{H}_{2} \mathrm{Se}$ dissociation at $723^{\circ} \mathrm{K}$ using Pearson's and our experimental data. A similar set of plors at $673^{\circ} \mathrm{K}$ and $698^{\circ} \mathrm{K}$ allows us to evaluate the forward reaction rate constant, $k_{t}$, for both independenty obtained data sers and also for the combined data set. The values are shown in 
Table 1. At $673^{\circ} \mathrm{K}$ there is a large discrepancy in the value of $k_{l}$ between our data and Pearson's.

If we assume an Arrhenius form for $k_{g}$, Its temperature dependence is:

$$
k_{f}-k_{f o} \exp (-E a / R T)
$$

Figure 5 is a plot of $\ln \left(k_{f}\right)$ vs $1 / T$. This leads to a value of $k_{f_{0}}-1.0 \times 10^{9} \mathrm{sec}^{-1}$, Ea $39.96 \mathrm{kcal} /$ mole which compares well with Pearson's reported value of $k_{20}-3.8 \times 10^{10}$ $\mathrm{sec}^{-1}$, Ea $-46.4 \mathrm{kcal} / \mathrm{mole}$.

To explain the data behavior at longer times, the reverse reaction of $\mathrm{H}_{2}$ with $\mathrm{Se}_{\mathrm{x}}$ needs to be considered.

If we assume the initial concentration of hydrogen and the $\mathrm{Se}_{\mathrm{x}}$ species to be zero, we can express equations 9 and 10 in terms of conversion of the reaction, $a$.

$\frac{d \alpha}{d t}-\frac{2}{3} k_{f}(1-\alpha)\left(1+\frac{\alpha}{2}\right)-k_{r} \frac{\sqrt{2}}{3} \alpha^{3 / 2}\left(1+\frac{\alpha}{2}\right)^{1 / 2}$

$\frac{d \alpha}{d t}-\frac{6}{7} k_{f}(1-\alpha)\left(1+\frac{\alpha}{6}\right)-\frac{6}{7}^{5 / 6} k_{k} a^{7 / 6}\left(1+\frac{\alpha}{6}\right)^{5 / 6}(15)$

where $\alpha-\frac{n_{H_{2} S e^{(t-0)}-\eta_{H_{2}} S e^{(t)}}^{n_{H_{2}} S e^{(t-0)}}}{n^{(t-0)}}$

$k_{r}$ may be estimated from the following relation:

$$
\frac{k_{f}}{k_{r}}-k_{y}
$$

where $k_{y}$ is given by equacion (2).

The above differential equation was then numerically solved to generate $\alpha$ as a function of time at a fixed temperature. Figure 6 shows the model curve generaced at $450^{\circ} \mathrm{C}$. The bold curve is generated considering $\mathrm{Se}_{2}$ as the product species and the dashed curve was generated for $\mathrm{Se}_{6}$ being the sole selenium product. The model curves overestimate the fraction $\mathrm{H}_{2} \mathrm{Se}$, suggesting that more than one Se species may be present in the product.

\section{CONCLUSIONS}

At equilibrium, over the cemperature range important for selenization of copper indium bilayers, the gas phase consists of about $50 x$ $\mathrm{Se}_{2}$ and $\mathrm{Se}_{6}$ and $50 \% \mathrm{H}_{2} \mathrm{Se}$.

At $450^{\circ} \mathrm{C}$, it takes about 10 minutes to reach equilibrium, which is about the same time that it takes to form $\mathrm{CuInSe}_{2}$.

At short times (less than 10 minutes) the race of dissociation of $\mathrm{H}_{2} \mathrm{Se}$ is ditectly proportional to its concentration. The reverse reaction becomes increasingly important as time increases.

The forward rate constant $k_{1}$ was calculated to be $1.0 \times 10^{\circ} \exp (-\mathrm{Ea} / \mathrm{RT})$ where Ea - $39.96 \mathrm{kcal} / \mathrm{mole}$.

Kinetic experiments on the pyrolysis of $\mathrm{H}_{2} \mathrm{Se}$ show that a reasonable fit to the data can be obtained by assuming $\mathrm{Se}_{6}$ as the decomposition product.

\section{ACKOOR EDGEMENTS}

This work was supported in part by the Department of Energy through the SERI Subcontract No. $X N-0-10023-1$. We appreciate helpful discussion with $B$. N. Baron and the editorial efforts of P. H. Newton.

\section{REFERENCES}

1. R. W. Birkmire, W. N. Shafarman, R. D. Varrin, "Options for Fabrication and Design of CuInSe, Based Solar Cells," Proc. 2lst IEEE Photovoltaic Specialists Conf., Kissimimee, Florida, May 21-25, 1990 , p. $529-534$ (1990).

2. K. C. Mills, Thermodynamic Data for Inorganic Sulphides, Selenides and Tellurides, Butterworth (1974).

3. Gmelin Handbook of Inorganic Chemistry, Vol. 10, Springer Verlag, (1988).

4. R. K. Pearson and G. R. Haugen, Int. J. of Hydrogen Energy, Vol 6, No. 5, p. 509-519, (1981).

5. R. D. Varrin, Jr., Ph.D. Dissertation, University of Delaware (1991). 


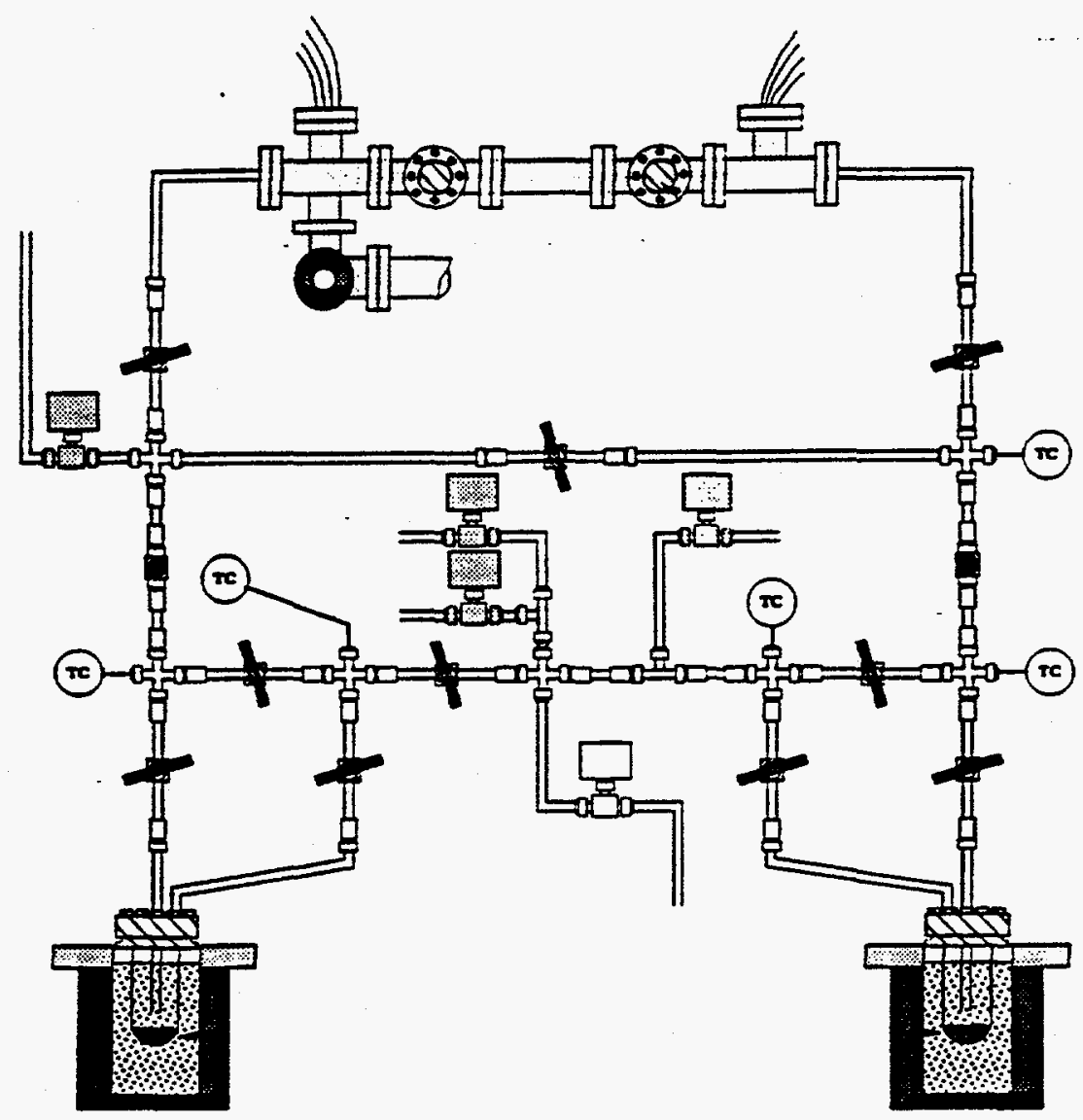

Figure 1: Closed loop selenization reactor using thermosiphon for transport of selenium or hydrogen selenide.

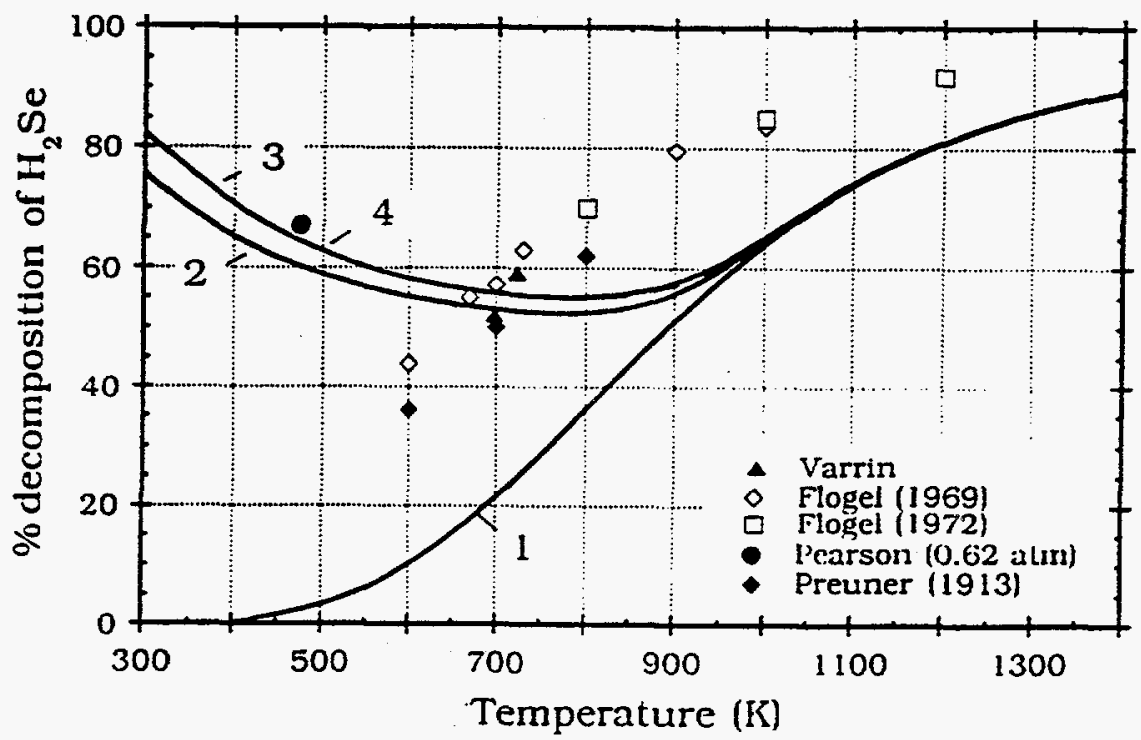

Figure 2: The predicted equilibrium dissociation of $\mathrm{H}_{2} \mathrm{Se}$ assuming 1) $\mathrm{Se}_{2}$ as the product species, 2) $\mathrm{Se}_{3}, \mathrm{Se}_{3}, \mathrm{Se}_{6}$ as the product species, 3) $\mathrm{Se}_{2}, \mathrm{Se}_{1}, \mathrm{Se}_{6}$. $\mathrm{Se}$, as the product species and, 4) $\mathrm{Se}, \mathrm{Se}_{2}, \mathrm{Se}_{2}, \mathrm{Se}_{5}, \mathrm{Se}_{5}, \mathrm{Se}_{6}, \mathrm{Se}_{7}$, as the product species. 


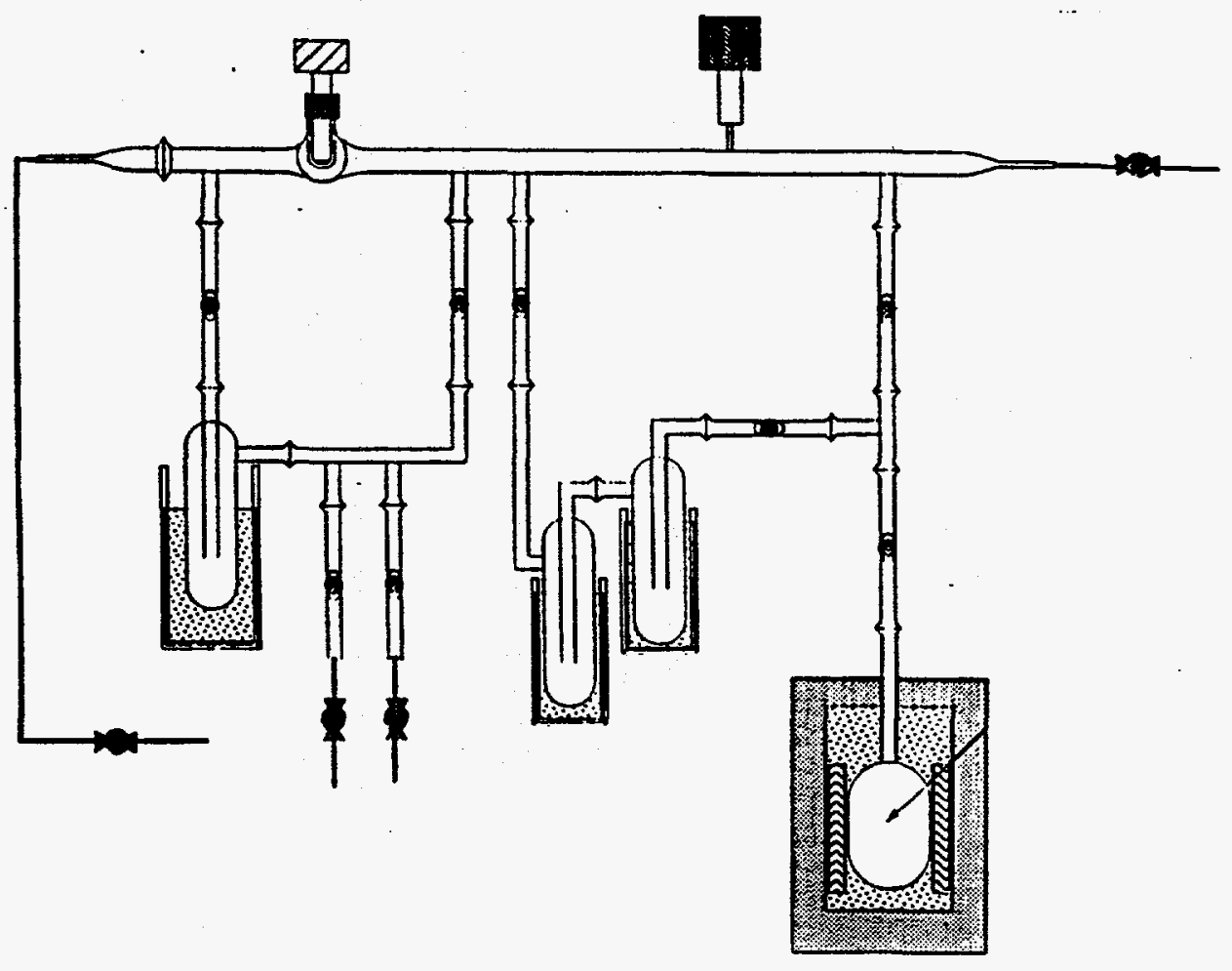

Figure 3: A schematic of the batch pyrolysis reactor used for our experiments.

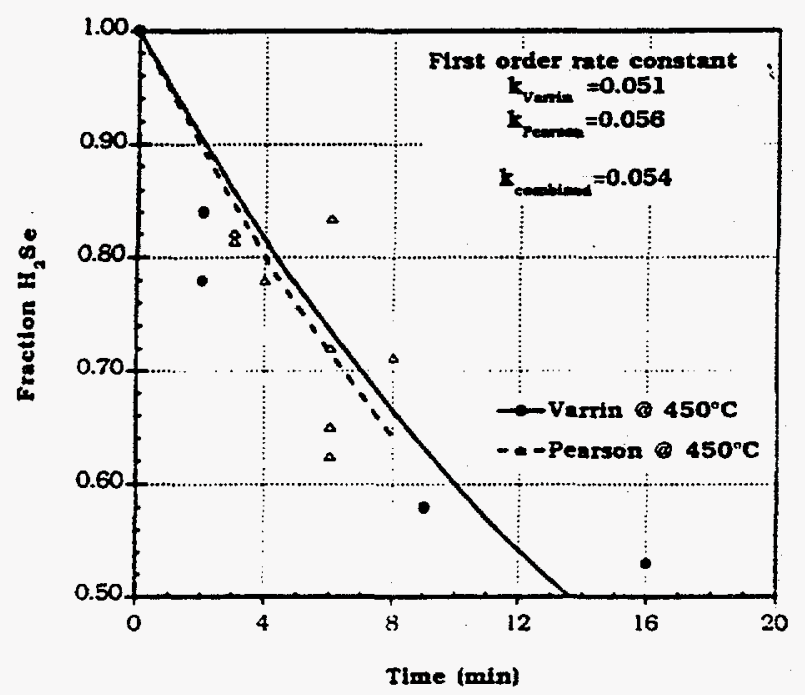

Figure 4: Determination of $k_{t}$ by the short time best fit to equation 12 for the two data sets.

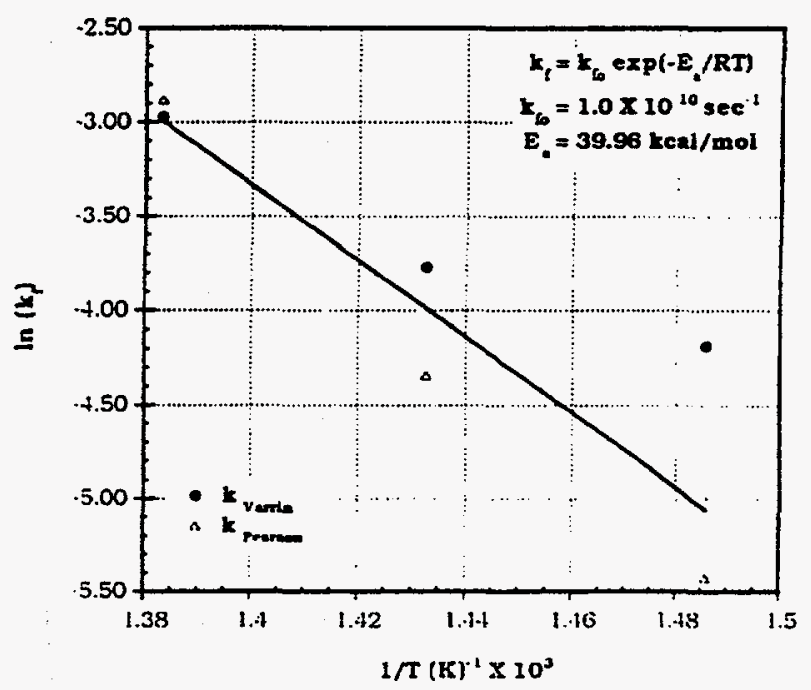

Figure 5: Determination of the activation energy for the torward rate constant $k_{\text {f }}$ by a best fit to equation 13 . 


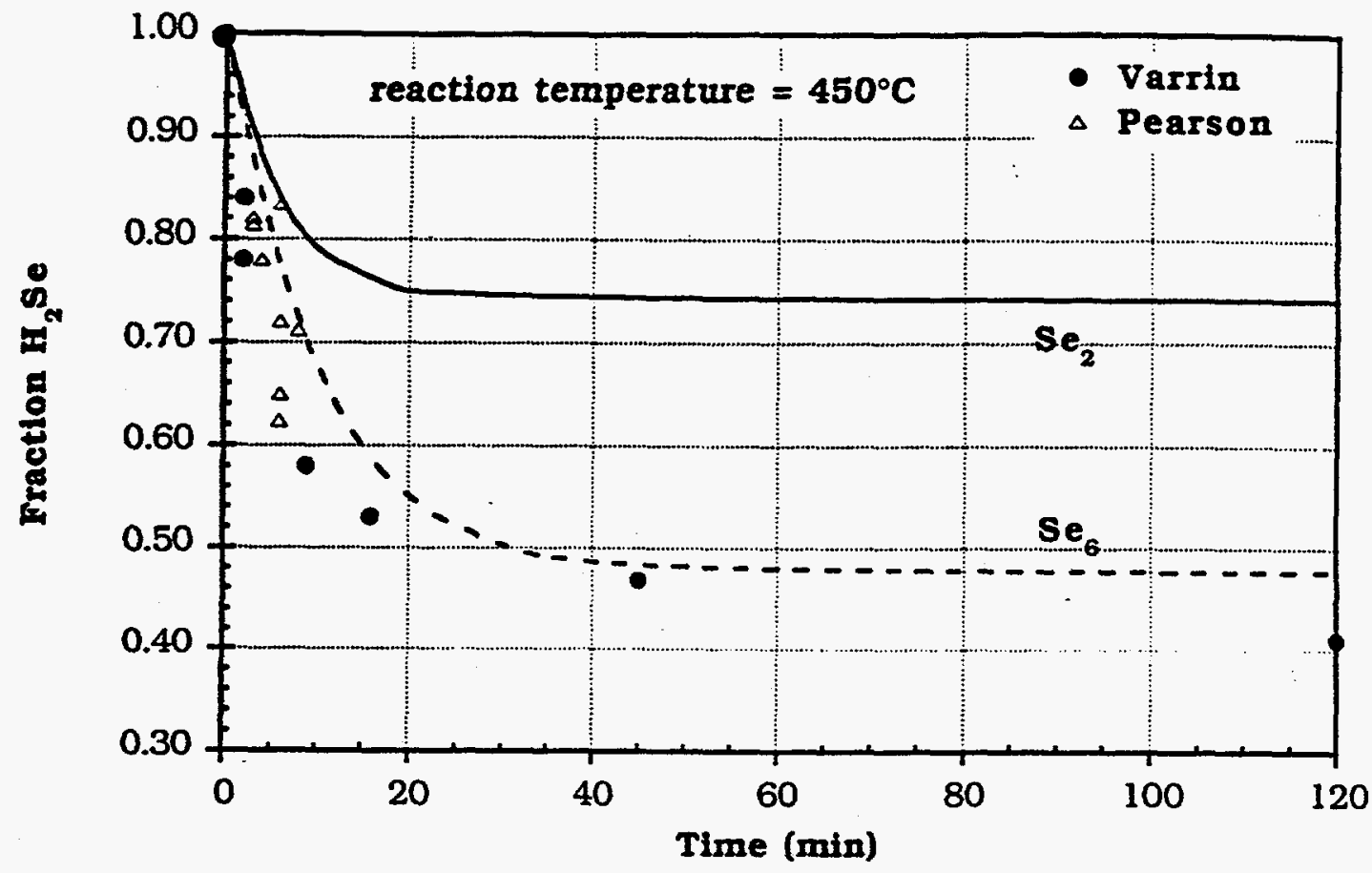

Figure 6: The model curves generated by consideration of the reverse reaction: 1) the bold curve considers $\mathrm{Se}_{2}$ as the dissociation product, 2) the dashed curve considers $\mathrm{Se}_{6}$ as the dissociation product.

Table 1: A summary of the forward rate constant $k_{2}$ calculated for the two data sets.

\begin{tabular}{|c|c|c|c|}
\hline $\mathbf{k}_{\mathbf{f}}$ & Varrins' data & $\begin{array}{c}\text { Pearsons' } \\
\text { data }\end{array}$ & Combined \\
\hline $673 \mathrm{~K}$ & 0.0152 & 0.0047 & 0.0068 \\
\hline $698 \mathrm{~K}$ & 0.023 & 0.013 & 0.016 \\
\hline $723 \mathrm{~K}$ & 0.051 & 0.056 & 0.054 \\
\hline
\end{tabular}


Appendix B

CdTe Stability Tests

Basic Current Voltage Parameters

Note 1: All Eff. and Jsc values are normalized to $100 \mathrm{~mW} / \mathrm{cm} 2 \mathrm{ELH}$ equivalent

Note 2: Numbers given for back contact are the thicknesses of the layer(s) in angstroms 


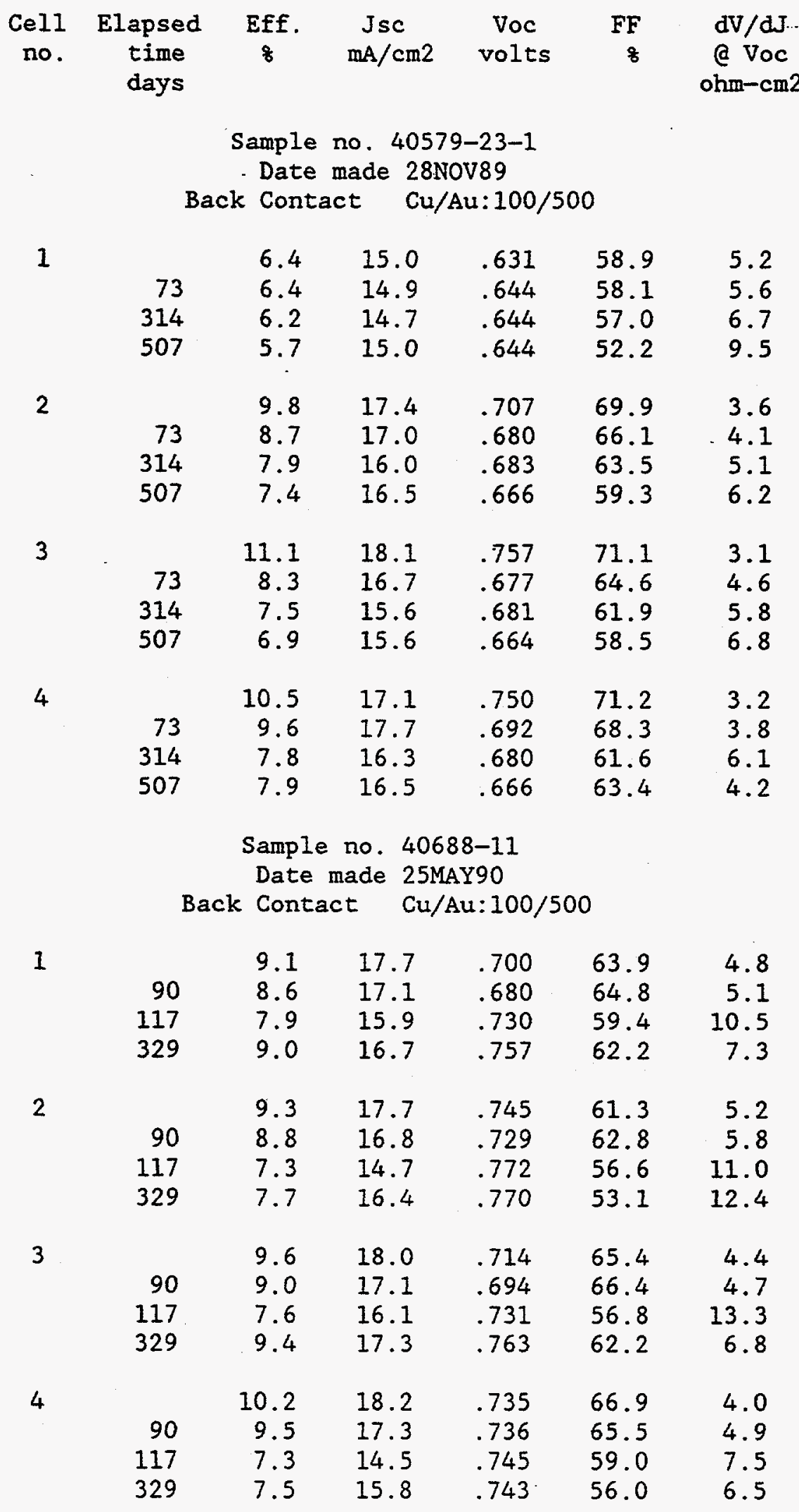




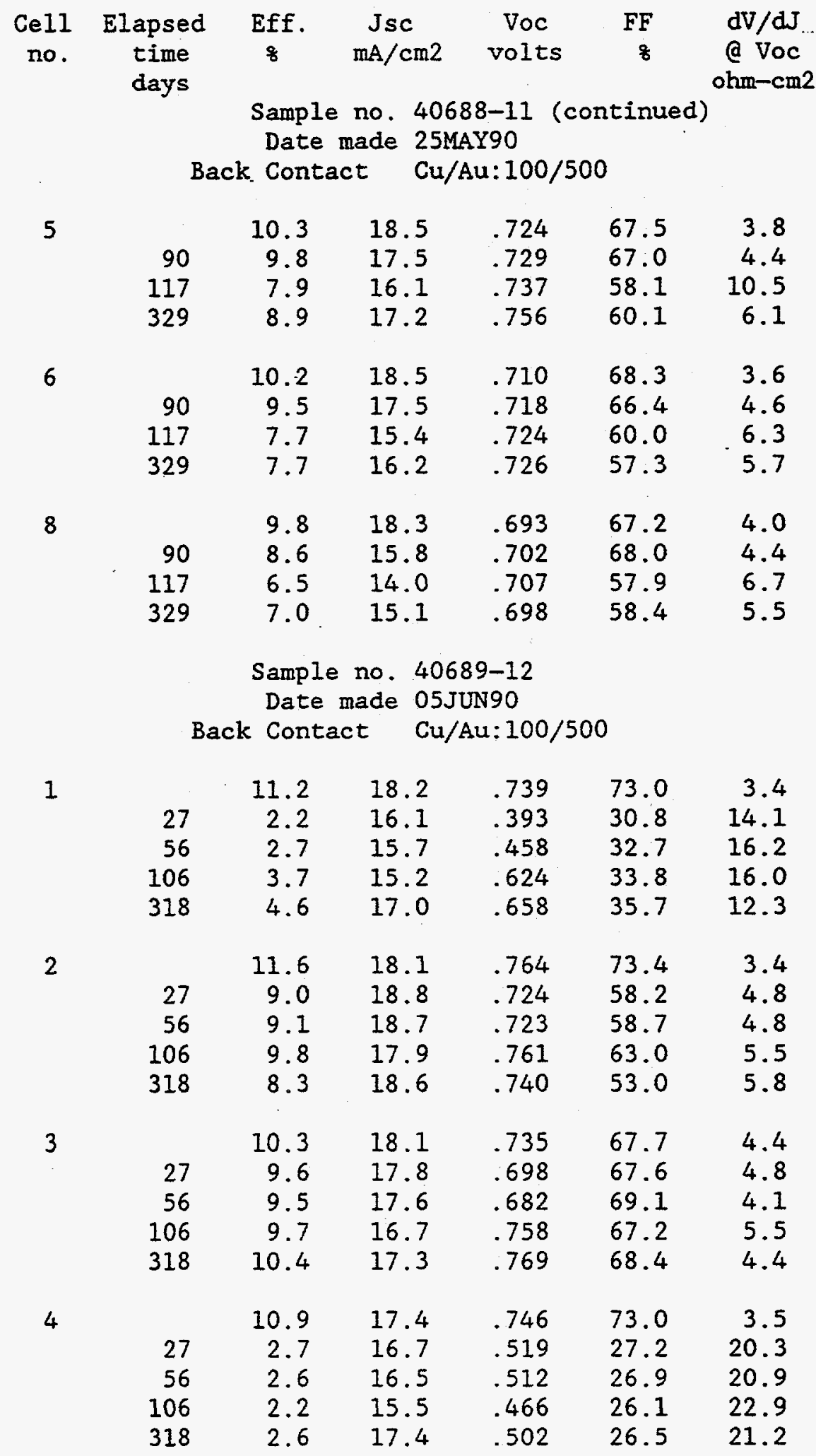




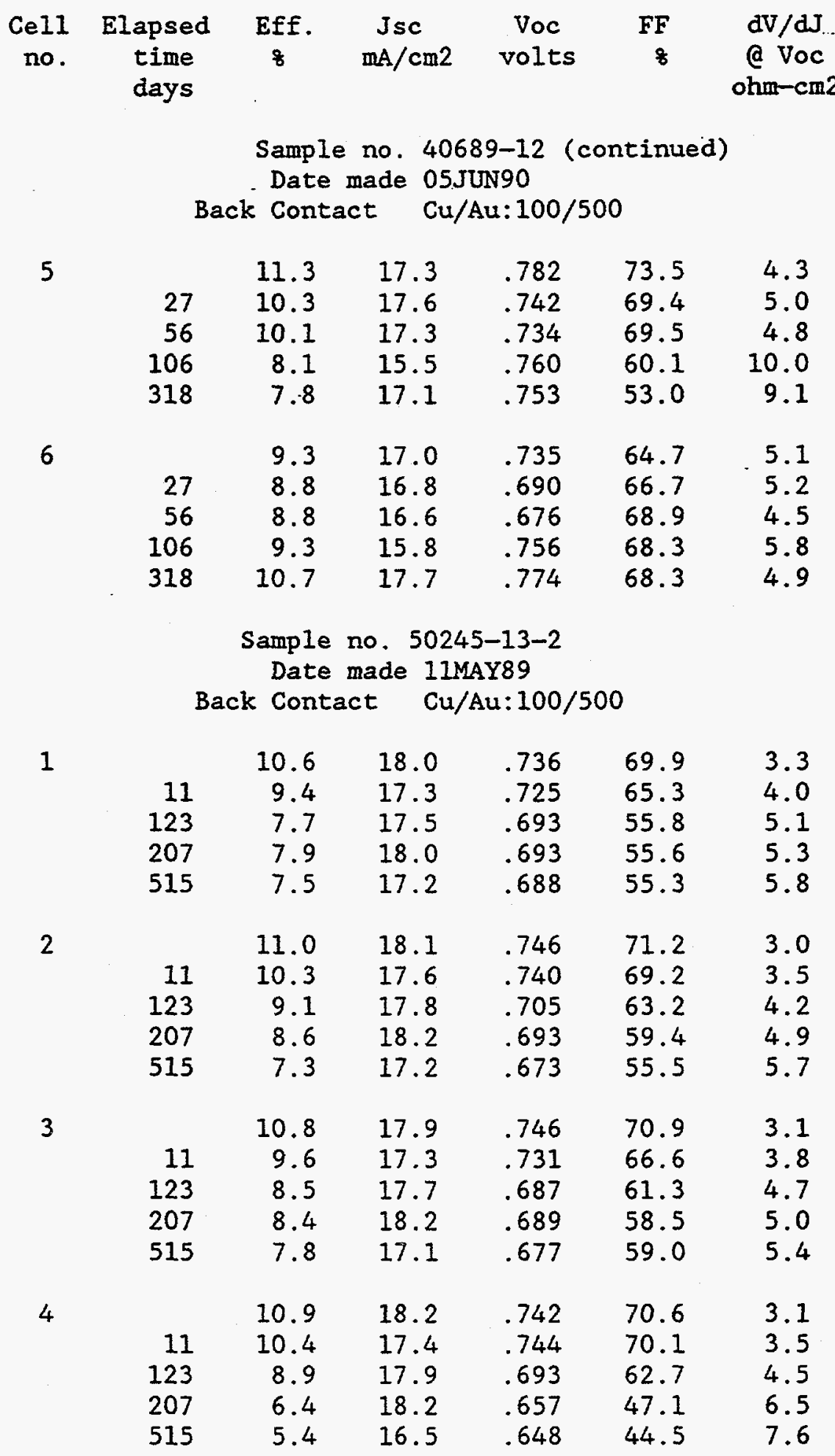




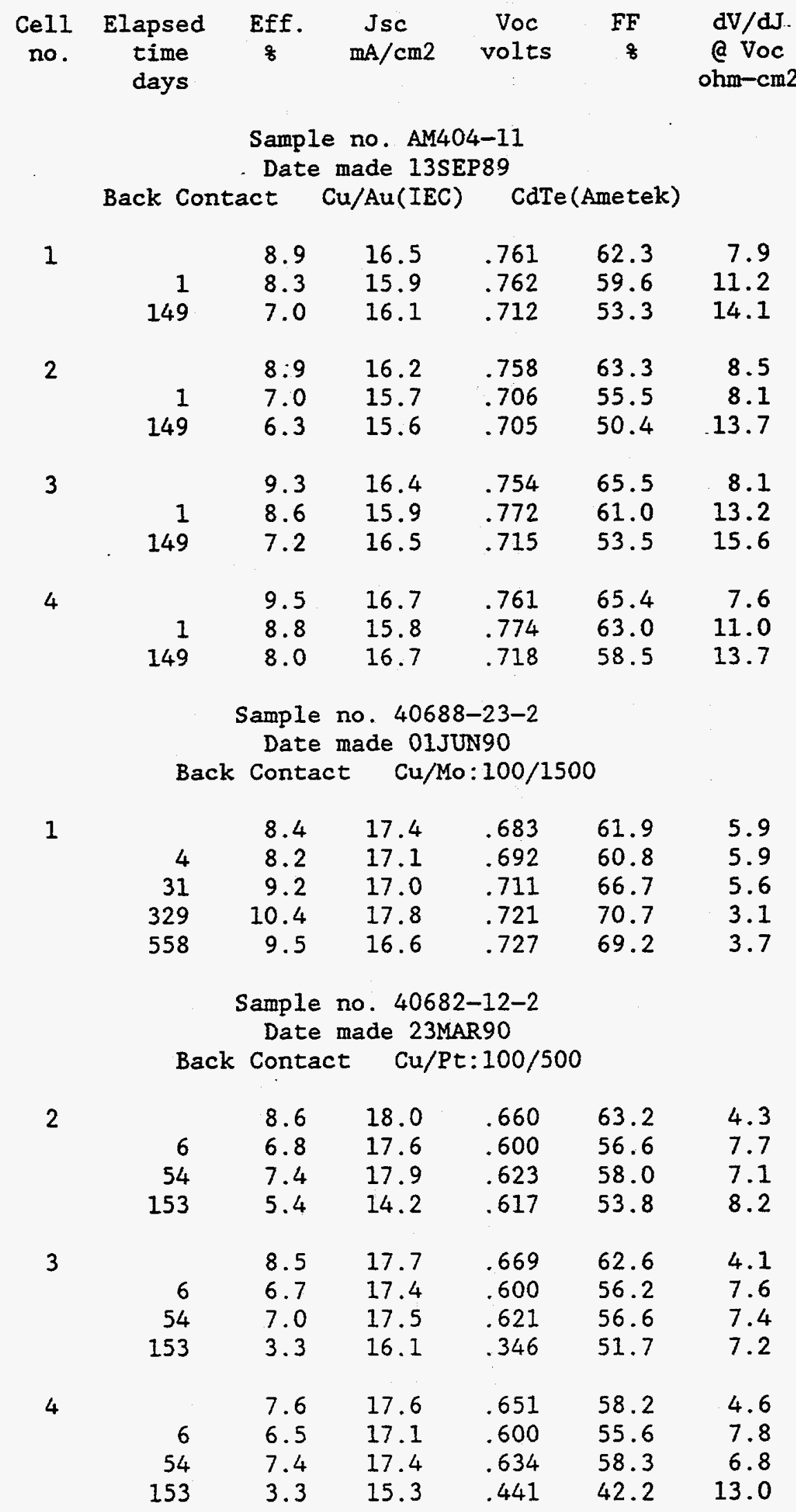




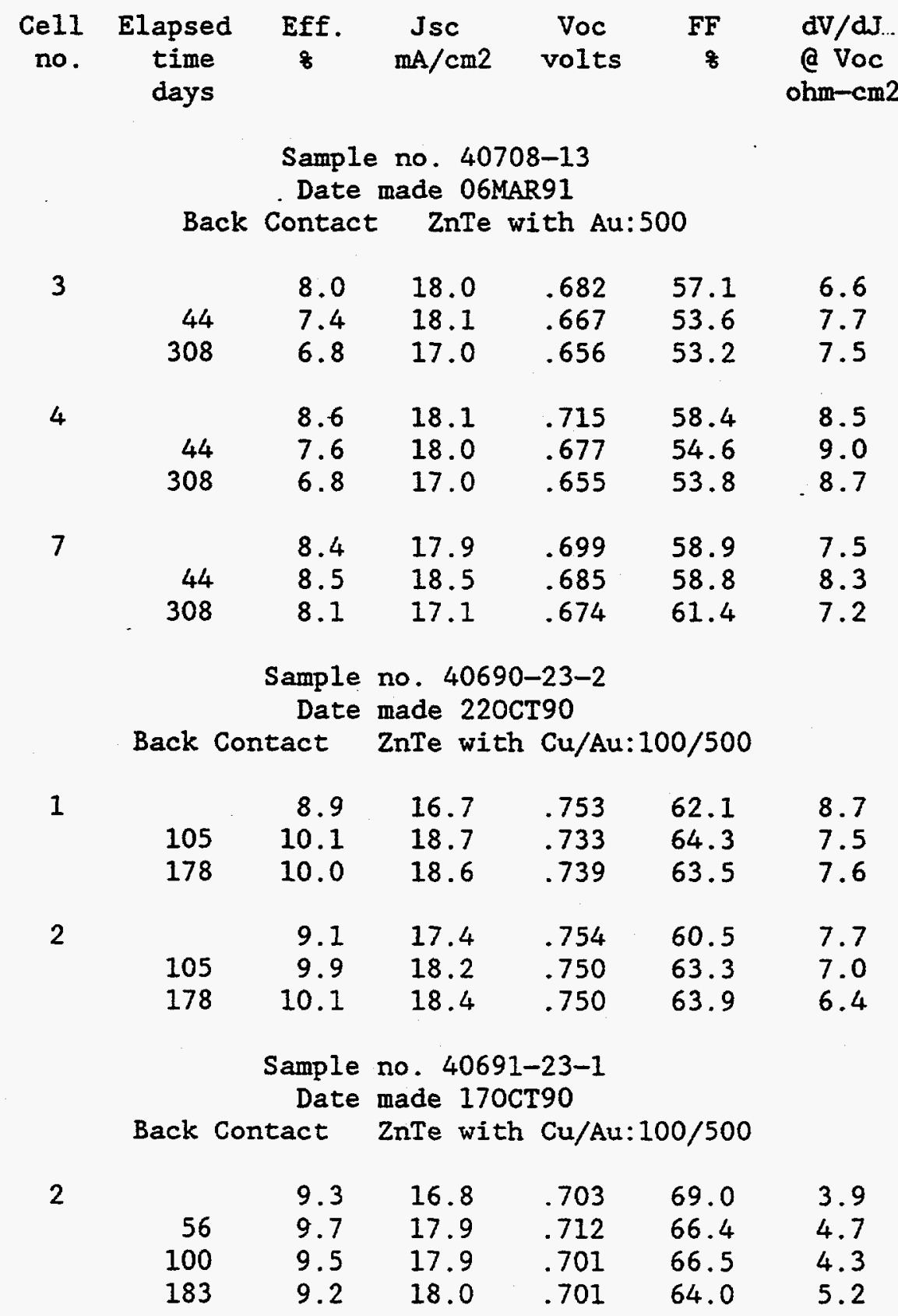




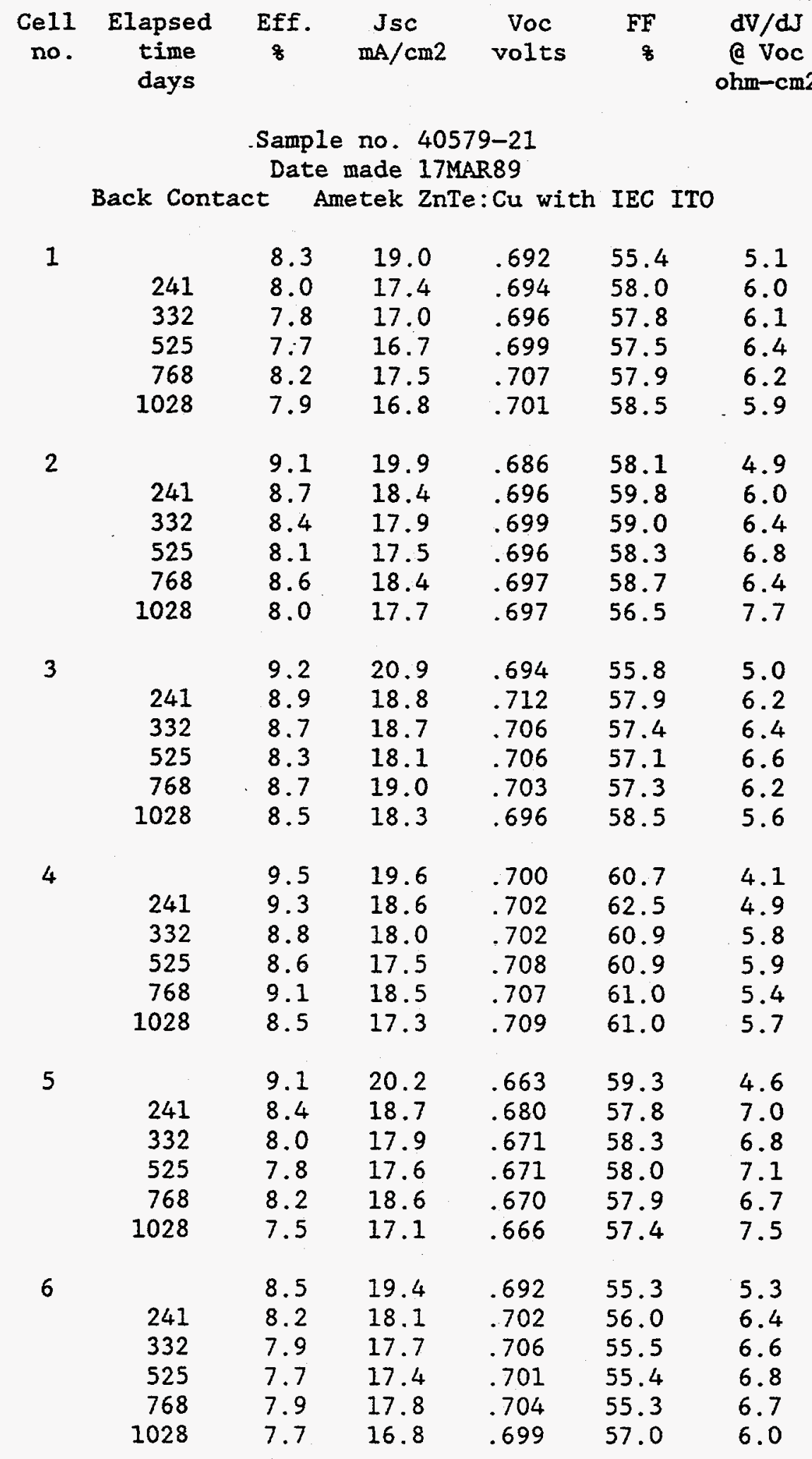




\begin{tabular}{|c|c|c|c|c|c|c|}
\hline $\begin{array}{l}\text { Cell } \\
\text { no. }\end{array}$ & $\begin{array}{c}\text { Elapsed } \\
\text { time } \\
\text { days }\end{array}$ & $\begin{array}{l}\text { Eff. } \\
8\end{array}$ & $\begin{array}{c}\mathrm{Jsc} \\
\mathrm{mA} / \mathrm{cm} 2\end{array}$ & $\begin{array}{l}\text { Voc } \\
\text { volts }\end{array}$ & $\begin{array}{r}F F \\
8\end{array}$ & $\begin{array}{c}\mathrm{dV} / \mathrm{dJ} \\
\text { a Voc } \\
\text { ohm-cm2 }\end{array}$ \\
\hline & & \multicolumn{5}{|c|}{$\begin{array}{c}\text { Sample no. 40579-21 } \\
\text { Date made 17MAR } 89\end{array}$} \\
\hline Back & Contact & Amet & $\mathrm{ZnTe}: \mathrm{C}$ & with IEC & ITO & ontinue \\
\hline 7 & $\begin{array}{r}241 \\
332 \\
525 \\
768 \\
1028\end{array}$ & $\begin{array}{l}9.5 \\
9.0 \\
8.8 \\
8.4 \\
8.9 \\
8.2\end{array}$ & $\begin{array}{l}19.9 \\
19.0 \\
18.5 \\
18.1 \\
19.0 \\
17.7\end{array}$ & $\begin{array}{l}.678 \\
.689 \\
.685 \\
.681 \\
.681 \\
.677\end{array}$ & $\begin{array}{l}61.8 \\
60.3 \\
60.6 \\
59.3 \\
60.0 \\
59.8\end{array}$ & $\begin{array}{l}4.1 \\
5.9 \\
6.1 \\
6.6 \\
6.6 \\
6.6\end{array}$ \\
\hline 8 & $\begin{array}{r}241 \\
332 \\
525 \\
768 \\
1028\end{array}$ & $\begin{array}{l}9.0 \\
8.5 \\
8.3 \\
8.0 \\
8.3 \\
7.8\end{array}$ & $\begin{array}{l}19.6 \\
18.9 \\
18.4 \\
18.0 \\
18.7 \\
17.7\end{array}$ & $\begin{array}{l}.675 \\
.670 \\
.682 \\
.677 \\
.674 \\
.679\end{array}$ & $\begin{array}{l}59.7 \\
58.6 \\
57.9 \\
57.4 \\
57.7 \\
57.0\end{array}$ & $\begin{array}{l}4.8 \\
6.3 \\
6.9 \\
7.2 \\
7.1 \\
7.6\end{array}$ \\
\hline 9 & $\begin{array}{r}241 \\
332 \\
525 \\
768 \\
1028\end{array}$ & $\begin{array}{l}9.4 \\
9.0 \\
9.1 \\
8.8 \\
9.1 \\
8.5\end{array}$ & $\begin{array}{l}19.8 \\
18.3 \\
18.4 \\
18.1 \\
18.7 \\
17.6\end{array}$ & $\begin{array}{l}.717 \\
.718 \\
.726 \\
.718 \\
.719 \\
.717\end{array}$ & $\begin{array}{l}57.8 \\
59.8 \\
59.5 \\
59.5 \\
59.0 \\
59.1\end{array}$ & $\begin{array}{l}4.7 \\
5.4 \\
5.7 \\
6.1 \\
6.2 \\
6.4\end{array}$ \\
\hline 10 & $\begin{array}{r}241 \\
332 \\
525 \\
768 \\
1028\end{array}$ & $\begin{array}{l}8.8 \\
8.6 \\
8.4 \\
8.0 \\
8.4 \\
8.0\end{array}$ & $\begin{array}{l}19.0 \\
18.5 \\
17.9 \\
17.3 \\
18.2 \\
17.1\end{array}$ & $\begin{array}{l}.678 \\
.679 \\
.688 \\
.685 \\
.688 \\
.689\end{array}$ & $\begin{array}{l}60.1 \\
59.9 \\
59.5 \\
58.9 \\
58.6 \\
59.3\end{array}$ & $\begin{array}{l}4.6 \\
5.9 \\
6.4 \\
7.1 \\
7.2 \\
7.1\end{array}$ \\
\hline
\end{tabular}

11

$\begin{array}{rrrrrr}241 & 9.1 & 18.6 & .708 & 60.6 & 4.8 \\ 332 & 8.9 & 18.1 & .712 & 60.2 & 5.2 \\ 525 & 8.7 & 17.8 & .708 & 60.5 & 5.1 \\ 768 & 9.1 & 18.6 & .711 & 60.3 & 5.2 \\ 1028 & 8.8 & 17.4 & .711 & 61.8 & 4.5\end{array}$

Sample no. 40690-22-1

Date made 250 CT 90

Back Contact ZnTe with Ni:2000

1

$\begin{array}{rrrrrr} & 8.0 & 15.2 & .616 & 74.8 & 4.0 \\ 6 & 7.2 & 15.0 & .586 & 71.7 & 4.8 \\ 183 & 7.8 & 15.5 & .679 & 64.6 & 4.5 \\ 412 & 1.6 & 11.6 & .445 & 27.3 & 16.7\end{array}$




\begin{tabular}{|c|c|c|c|c|c|c|c|}
\hline $\begin{array}{r}\text { Cell } \\
\text { no. }\end{array}$ & $\begin{array}{c}\text { Elapsed } \\
\text { time } \\
\text { days }\end{array}$ & $\begin{array}{c}\text { Eff. } \\
\frac{q}{8}\end{array}$ & $\begin{array}{c}\mathrm{Jsc} \\
\mathrm{mA} / \mathrm{cm} 2\end{array}$ & $\begin{array}{l}\text { Voc } \\
\text { volts }\end{array}$ & $\begin{array}{r}F F \\
8\end{array}$ & & $\begin{array}{l}\mathrm{IV} / \mathrm{dJ} . \\
\mathrm{Voc} \\
\mathrm{im}-\mathrm{cm} 2\end{array}$ \\
\hline & & $\begin{array}{l}\text { Sample } \\
\text { Date }\end{array}$ & $\begin{array}{c}\text { no. MW9 } \\
\text { made } 14 \mathrm{~A}\end{array}$ & & & & \\
\hline Back & Contact & ZnTe wit & h $\mathrm{Ni} / \mathrm{Al}$ & Made & entirely & by & Amet \\
\hline 1 & $\begin{array}{r}314 \\
742 \\
1000\end{array}$ & $\begin{array}{r}10.1 \\
10.3 \\
9.3 \\
9.9\end{array}$ & $\begin{array}{l}18.8 \\
19.1 \\
18.1 \\
19.1\end{array}$ & $\begin{array}{l}.733 \\
.747 \\
.723 \\
.725\end{array}$ & $\begin{array}{l}64.2 \\
63.1 \\
61.9 \\
62.3\end{array}$ & & $\begin{array}{l}5.2 \\
5.6 \\
5.9 \\
5.5\end{array}$ \\
\hline 2 & $\begin{array}{r}314 \\
742 \\
1000\end{array}$ & $\begin{array}{l}9.2 \\
9.2 \\
9.0 \\
9.2\end{array}$ & $\begin{array}{l}18.3 \\
18.9 \\
19.6 \\
19.0\end{array}$ & $\begin{array}{l}.696 \\
.677 \\
.650 \\
.672\end{array}$ & $\begin{array}{l}62.8 \\
63.2 \\
61.9 \\
62.7\end{array}$ & & $\begin{array}{l}6.5 \\
6.1 \\
6.1 \\
6.2\end{array}$ \\
\hline 3 & $\begin{array}{r}314 \\
742 \\
1000\end{array}$ & $\begin{array}{l}10.1 \\
10.3 \\
10.9 \\
10.0\end{array}$ & $\begin{array}{l}18.5 \\
19.0 \\
19.7 \\
18.8\end{array}$ & $\begin{array}{l}.749 \\
.759 \\
.756 \\
.752\end{array}$ & $\begin{array}{l}63.5 \\
62.7 \\
64.3 \\
62.0\end{array}$ & & $\begin{array}{l}5.9 \\
6.5 \\
5.7 \\
7.0\end{array}$ \\
\hline 4 & $\begin{array}{r}314 \\
742 \\
1000\end{array}$ & $\begin{array}{r}9.7 \\
9.6 \\
10.3 \\
9.5\end{array}$ & $\begin{array}{l}18.1 \\
18.7 \\
19.5 \\
18.8\end{array}$ & $\begin{array}{l}.720 \\
.710 \\
.703 \\
.698\end{array}$ & $\begin{array}{l}65.2 \\
63.4 \\
65.8 \\
63.6\end{array}$ & & $\begin{array}{l}6.1 \\
6.1 \\
5.2 \\
6.2\end{array}$ \\
\hline 5 & $\begin{array}{r}314 \\
742 \\
1000\end{array}$ & $\begin{array}{l}7.9 \\
7.8 \\
8.2 \\
7.5\end{array}$ & $\begin{array}{l}18.0 \\
18.9 \\
19.8 \\
18.6\end{array}$ & $\begin{array}{l}.628 \\
.610 \\
.601 \\
.591\end{array}$ & $\begin{array}{l}61.0 \\
59.1 \\
60.6 \\
59.9\end{array}$ & & $\begin{array}{l}6.5 \\
6.1 \\
5.0 \\
5.5\end{array}$ \\
\hline 6 & $\begin{array}{r}314 \\
742 \\
1000\end{array}$ & $\begin{array}{l}8.1 \\
8.2 \\
8.4 \\
7.9\end{array}$ & $\begin{array}{l}18.7 \\
19.6 \\
19.9 \\
19.5\end{array}$ & $\begin{array}{l}.634 \\
.627 \\
.622 \\
.611\end{array}$ & $\begin{array}{l}59.4 \\
58.7 \\
59.1 \\
57.8\end{array}$ & & $\begin{array}{l}6.4 \\
5.7 \\
4.9 \\
6.0\end{array}$ \\
\hline
\end{tabular}




\begin{tabular}{|c|c|c|c|}
\hline $\begin{array}{c}\text { Document Control } \\
\text { Page }\end{array}$ & $\begin{array}{l}\text { 1. NREL Report No. } \\
\text { NREL/TP-451-5094 }\end{array}$ & $\begin{array}{l}\text { 2. NTIS Accession No. } \\
\text { DE93000022 }\end{array}$ & 3. Recipient's Accession No. \\
\hline \multirow{2}{*}{\multicolumn{3}{|c|}{$\begin{array}{l}\text { 4. Title and Subtitle } \\
\text { Polycrystalline Thin Film Materials and Devices }\end{array}$}} & $\begin{array}{l}\text { 5. Publication Date } \\
\text { October } 1992\end{array}$ \\
\hline & & & 6. \\
\hline \multicolumn{3}{|c|}{$\begin{array}{l}\text { 7. Author(s) } \\
\text { B.N. Baron, R.W. Birkmire, J.E. Phillips, W.N. Shafarman, S.S. Hegedus, } \\
\text { B.E. McCandless }\end{array}$} & 8. Performing Organization Rept. No. \\
\hline \multirow{2}{*}{\multicolumn{3}{|c|}{$\begin{array}{l}\text { 9. Performing Organization Name and Address } \\
\text { Institute of Energy Conversion } \\
\text { University of Delaware } \\
\text { Newark, Delaware } 19716\end{array}$}} & $\begin{array}{l}\text { 10. Project/TaskMork Unit No. } \\
\text { PV231101 }\end{array}$ \\
\hline & & & $\begin{array}{l}\text { 11. Contract (C) or Grant (G) No. } \\
\text { (C) XN-0-10023-1 } \\
\text { (G) }\end{array}$ \\
\hline \multirow{2}{*}{\multicolumn{3}{|c|}{$\begin{array}{l}\text { 12. Sponsoring Organization Name and Address } \\
\text { National Renewable Energy Laboratory } \\
1617 \text { Cole Blvd. } \\
\text { Golden, CO } 80401-3393\end{array}$}} & $\begin{array}{l}\text { 13. Type of Report \& Period Covered } \\
\text { Technical Report } \\
\text { 16 January } 1991 \text { - } 15 \text { January } 1992\end{array}$ \\
\hline & & & 14. \\
\hline \multicolumn{4}{|c|}{$\begin{array}{l}\text { 15. Supplementary Notes } \\
\text { NREL technical monitor: B. von Roedern }\end{array}$} \\
\hline \multicolumn{4}{|c|}{$\begin{array}{l}\text { This report describes research to obtain an understanding of the materials processing, properties, and performance of } \\
\text { polycrystalline thin-film CuInSe } e_{2} \text { and CdTe solar cells. Such an understanding is needed to achieve the goals for efficiency, } \\
\text { reliability, and cost for flat-plate thin-film photovoltaic (PV) systems as defined in the national PV program, and to support } \\
\text { the development of a competitive U.S. PV industry through collaboration with engineers and scientists at other laboratories. } \\
\text { The report presents results and conclusions of Phase II of a multiyear research program on polycrystalline thin-film } \\
\text { heterojunction solar cells. The research consisted of investigating the relationships between processing, materials properties, } \\
\text { and device performance. The relationship was quantified by device modeling and analysis. The analysis of thin-film } \\
\text { polycrystalline heterojunction solar cells explains how minority carrier recombination at the metallurgical interface and at grain } \\
\text { boundaries can be greatly reduced by the proper doping of the window and absorber layers. Additional analysis and } \\
\text { measurements show that the present solar cells are limited by the magnitude of the diode current that appears to be caused by } \\
\text { recombination in the space-charge region. }\end{array}$} \\
\hline \multicolumn{4}{|c|}{$\begin{array}{l}\text { 17. Document Analysis } \\
\text { a. Descriptors } \\
\text { polycrystalline ; thin films ; electronic materials ; electronic devices ; photovoltaics ; solar cells }\end{array}$} \\
\hline \multirow{2}{*}{\multicolumn{3}{|c|}{$\begin{array}{l}\text { 18. Availability Statement } \\
\text { National Technical Information Service } \\
\text { U.S. Department of Commerce } \\
5285 \text { Port Royal Road } \\
\text { Springfield, VA } 22161\end{array}$}} & $\begin{array}{l}\text { 19. No. of Pages } \\
113\end{array}$ \\
\hline & & & $\begin{array}{l}\text { 20. Price } \\
\text { A06 }\end{array}$ \\
\hline
\end{tabular}

